\title{
St. Vincent and the Grenadines: 2006 Article IV Consultation-Staff Report; Staff Statement; and Public Information Notice on the Executive Board Discussion
}

Under Article IV of the IMF's Articles of Agreement, the IMF holds bilateral discussions with members, usually every year. In the context of the 2006 Article IV consultation with St. Vincent and the Grenadines, the following documents have been released and are included in this package:

- The staff report for the 2006 Article IV consultation, prepared by a staff team of the IMF, following discussions that ended on August 2, 2006, with the officials of St. Vincent and the Grenadines on economic developments and policies. Based on information available at the time of these discussions, the staff report was completed on December 8, 2006. The views expressed in the staff report are those of the staff team and do not necessarily reflect the views of the Executive Board of the IMF.

- $\quad$ A staff statement of January 11, 2007 updating information on recent developments.

- $\quad$ A Public Information Notice (PIN) summarizing the views of the Executive Board as expressed during its January 17, 2007 discussion of the staff report that concluded the Article IV consultation.

The document listed below will be separately released.

\section{Statistical Appendix}

The policy of publication of staff reports and other documents allows for the deletion of market-sensitive information.

To assist the IMF in evaluating the publication policy, reader comments are invited and may be sent by e-mail to publicationpolicy@imf.org.

$$
\begin{gathered}
\text { Copies of this report are available to the public from } \\
\text { International Monetary Fund • Publication Services } \\
70019^{\text {th }} \text { Street, N.W. • Washington, D.C. } 20431 \\
\text { Telephone: (202) 623-7430 • Telefax: (202) 623-7201 } \\
\text { E-mail: publications@imf.org • Internet: http://www.imf.org }
\end{gathered}
$$

Price: $\$ 18.00$ a copy

\section{International Monetary Fund Washington, D.C.}





\title{
INTERNATIONAL MONETARY FUND
}

\section{ST. VINCENT AND THE GRENADINES}

\section{Staff Report for the 2006 Article IV Consultation}

\author{
Prepared by the Staff Representatives for the 2006 Consultation with \\ St. Vincent and the Grenadines
}

Approved by Christopher Towe and Matthew Fisher

December 8, 2006

Discussions: A staff team comprising Paul Cashin (Head), Montfort Mlachila, Emilio Pineda (all WHD), and Junko Koeda (FIN) visited Kingstown during July 25-August 3, 2006. The mission met with the Prime Minister (and Minister of Finance), the Director General of the Ministry of Finance, other senior government officials, opposition parliamentarians and political leaders, representatives of the financial and business sectors, as well as farmers, trade unions and civil society. Staff of the Eastern Caribbean Central Bank (ECCB) and Caribbean Development Bank (CDB) also participated. Mr. Peter Charleton, Alternate Executive Director for St. Vincent and the Grenadines, and David O. Robinson (WHD), joined for the final discussions, which also overlapped with the ECCU Regional Discussions with St. Vincent and the Grenadines.

Economic Background: St. Vincent and the Grenadines is a 32-island economy in the eastern Caribbean, with a population of about 106,000 and per capita GDP of about US\$4,300. It is one of eight eastern Caribbean countries and territories comprising the Eastern Caribbean Currency Union (ECCU), and its GDP accounts for 12 percent of the combined ECCU GDP. The ECCU has a common central bank, the ECCB, and a common currency, the Eastern Caribbean (EC) dollar. The EC dollar has been pegged to the U.S. dollar at the rate of EC \$2.70 per U.S. dollar since July 1976. St. Vincent and the Grenadines has accepted the obligations of Article VIII, Sections 2, 3, and 4, and maintains an exchange system free of restrictions on payments and transfers for current international transactions.

Political Situation: St. Vincent and the Grenadines has a unicameral parliament consisting of 21 members15 elected and 6 appointees. During elections held in December 2005, Prime Minister Ralph Gonsalves and his Unity Labour Party won a second term, retaining their 12 to 3 parliamentary majority. A key issue during the election concerned the planned large-scale infrastructure projects that the government deemed necessary to ensure medium-term growth as the country transitions away from its dependence on agriculture.

Previous Board Discussion: At the conclusion of the last Article IV consultation, on July 13, 2005, Executive Directors expressed concern about the fiscal deterioration and rising public sector debt. They underscored the need for strong fiscal action to reduce debt sustainability risks, while making room for social and other priority outlays. Directors also urged that measures be taken to strengthen the effectiveness of financial sector supervision. The public information notice (PIN), which contains the summing up of Executive Directors' discussions and policy recommendations, can be found on the IMF website at: 
Executive Summary 4

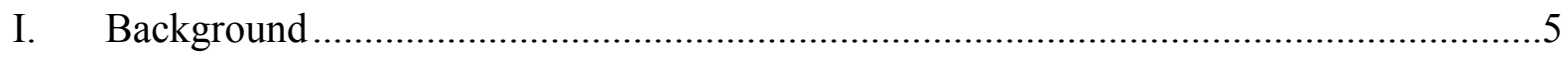

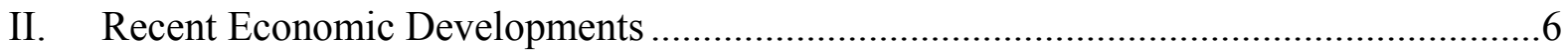

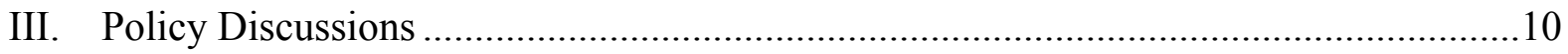

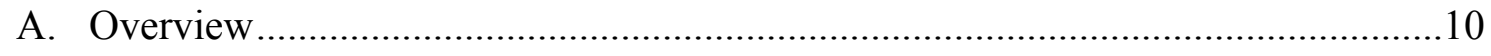

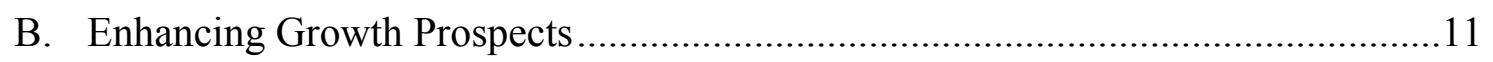

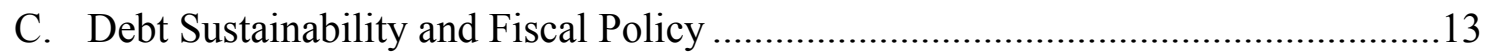

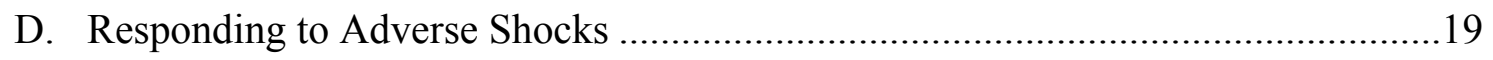

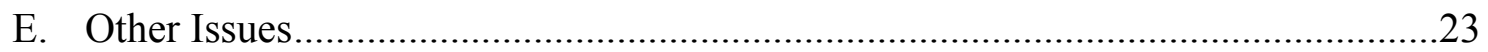

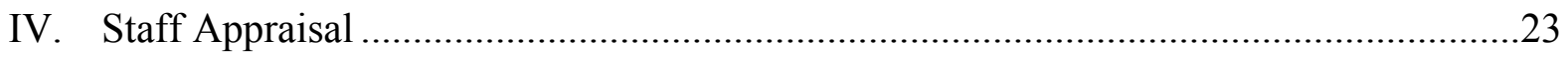

Boxes

1. Economic Impact of the 2007 Cricket World Cup .............................................. 7

2. International Airport Project and Financing ....................................................... 12

3. Long-Term-Solvency of the National Insurance Services (NIS) and its Role

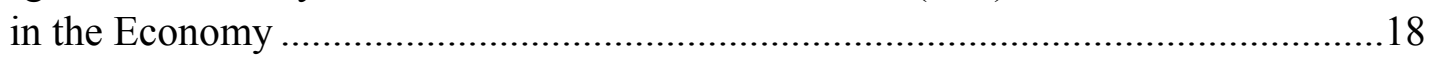

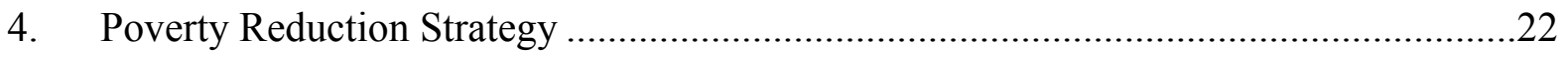

Figures

1. Macroeconomic Developments, 1990-2005 …...................................................25

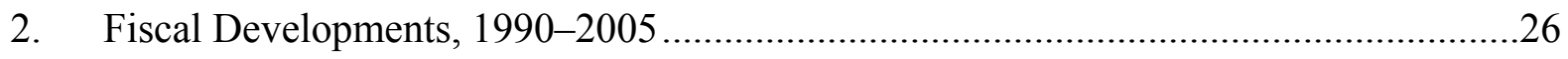

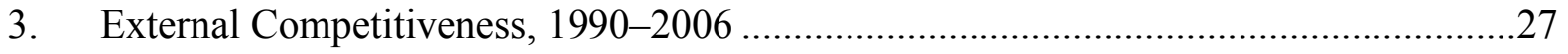

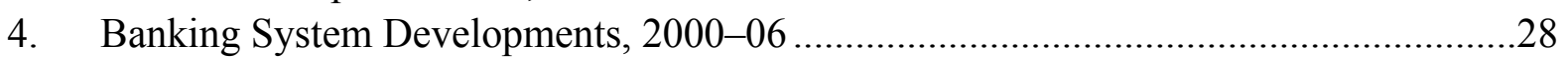

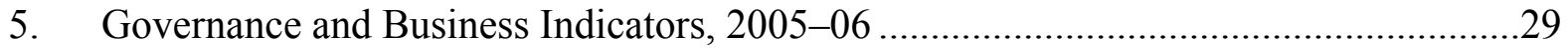

6. Public Debt Sustainability: Bound Tests ............................................................. 30

Tables

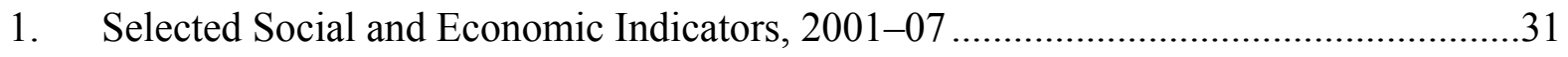

2. Summary of Central Government Operations, 2001-11 ..........................................3

3. Summary of Central Government Operations, 2001-11 ...........................................33

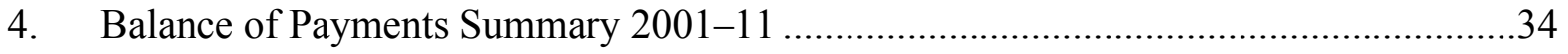

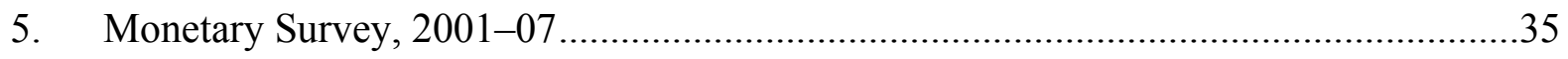

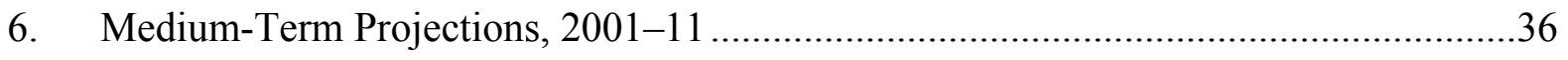

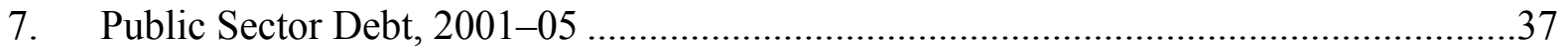

8. Public Sector Debt Sustainability Framework, 2001-11 ............................................38

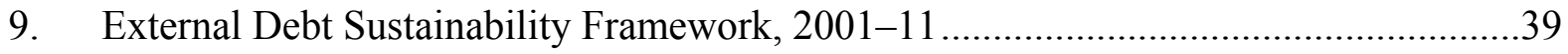


10. Indicators of External and Financial Vulnerability, 2001-06.....................................40

11. Millennium Development Goals Country Profile.....................................................41

\section{Annex}

I. Medium-Term Outlook Under Alternative Fiscal Scenarios

Appendices

I. Relations with the Fund

II. Relations with the World Bank Group....................................................................47

III. Relations with the Caribbean Development Bank ....................................................50

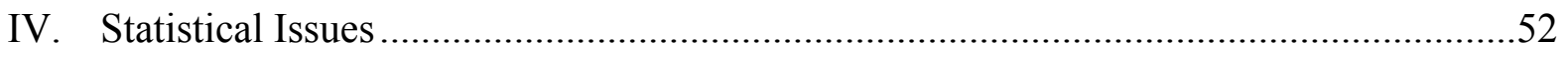




\section{EXECUTIVE SUMMARY}

\section{Recent Developments}

Near-term economic prospects appear favorable. Growth is expected to pick up to 4 percent in 2006, reflecting continued expansion in tourism and tourism-related services, a rebound in weather-affected agricultural production, as well as strong public sector construction activity. Further acceleration in economic activity is expected in 2007 , underpinned by continued expansion in tourism and rising domestic investment.

The fiscal situation remains of concern. Fiscal imbalances continued to expand in 2005, and while there has been some consolidation in 2006, public debt is accelerating. Debt servicing absorbs the equivalent of about 25 percent of current revenues, and the mission estimated that on current policies and assuming medium-term growth of about 4 percent per year, public debt would be on an unsustainable path, reaching 107 percent of GDP by 2011.

\section{Staff Appraisal}

A strong, up-front fiscal adjustment is necessary to reverse past increases in the debt burden. While staff commends the authorities for the planned adoption of the VAT and the reduction of fuel subsidies, more needs to be done, particularly in prioritizing and properly phasing infrastructure-enhancing projects, and ensuring that these are funded with grant financing and highly concessional loans. The government's wage bill, which accounts for about half of all current expenditures, also needs to be reduced.

\section{Limited progress has been made in strengthening St. Vincent and the Grenadines' financial system. The balance sheet of the state-owned National Commercial Bank has improved with a reduction in its nonperforming loans, and the prudential and regulatory environment of the country's financial sector has strengthened in recent years. However, vulnerabilities remain among local banks with high exposure to government and weakly- regulated nonbank financial institutions.}

St. Vincent and the Grenadines still faces the economic and social challenge of coping with the erosion of European Union trade preferences. The authorities have attempted to ameliorate the transition cost of the movement of resources away from agriculture by the provision of well-targeted social safety nets for displaced farmers and agricultural workers. The country should effectively use planned European Union assistance to ease the transition of the economy out of banana production.

St. Vincent and the Grenadines remains vulnerable to natural disasters. The authorities should further enhance their efforts to bolster disaster preparedness and mitigation, including by transferring disaster risk through insurance of public assets and regional risk pooling. 


\section{BACKGROUND}

1. St. Vincent and the Grenadines is a small, open economy that has increasingly relied on its tourism sector. The export-oriented services sector accounts for about threequarters of total value added, and the import content of both domestic consumption and investment is high. The role of the traditionally-dominant agriculture sector has declined sharply in recent decades (the contribution of bananas to GDP has declined from 10 percent in the early 1990s to about 2 percent in 2005), but agricultural crops (particularly bananas) remain important in supporting the incomes of the country's large rural population.

\section{Unlike in most other ECCU countries, GDP growth in St. Vincent and the} Grenadines has sputtered over the last year (Figure 1). Growth in the region rebounded after 2001, mainly through the expansion of the tourism sector, as well as Cricket World Cup-related construction activities. However, growth slackened in 2005, reflecting a slowdown in construction and a downturn in weather-affected agricultural production.

3. The fiscal situation has continued to deteriorate since the late 1990s, with a rapid rise in debt levels (Figure 2). This has reflected insufficient expenditure contraction in the face of declining revenues and, as a consequence, public debt has risen from less than 50 percent of GDP in 1997 to 82 percent of GDP by 2005.

4. Despite being the poorest country in the ECCU, St. Vincent and the Grenadines has strong social indicators. St. Vincent and the Grenadines exhibits near-universal adult literacy and has the same average life expectancy at birth as the ECCU average. This reflects targeted interventions to reduce poverty (such as the provision of low-income housing) and access to free education, including at the secondary level.
St. Vincent and the Grenadines: Social and Demographic Indicators

\begin{tabular}{lcc}
\hline & $\begin{array}{c}\text { St. Vincent and } \\
\text { the Grenadines }\end{array}$ & ECCU \\
\hline & & \\
Population (in thousand), estimate 2006 & 106 & 568 \\
Poverty headcount index, 2001 1/ & 38 & 29 \\
HDI rank, out of 177 countries, 2004 & 87 & 73 \\
Life expectancy at birth (years), 2003 & 73 & 74 \\
Adult illiteracy rate (percent), 2001 & 11 & 8 \\
AIDS incidence per 100,000, 2004 & 99 & 29 \\
Immunization coverage (percent), 2000 & 95 & 93 \\
Per capita energy availability (calories per day) & 2,660 & 2,695 \\
Infant mortality rate (per 100,000 live births), 2003 & 22 & 17 \\
GDP per capita (US\$) in 2006, estimate & 4,364 & 6,479 \\
\hline 1/ Percentage of population living below each county &
\end{tabular}

1/ Percentage of population living below each country's locally-defined poverty line. 


\section{RECENT ECONOMIC DEVELOPMENTS}

\section{Real GDP growth slowed to 2.2 percent in $\mathbf{2 0 0 5}$, but is expected to rebound in}

2006. The 2005 slowdown reflected a sharp contraction in the construction sector, and a further deterioration in agricultural production, as well as a drop in tourism-related transportation and trade. Growth in 2006 is estimated to have accelerated to just over 4 percent owing to a pick up in construction and tourism-related services, as well as a rebound in agricultural production. Average annual inflation rose to 4 percent in 2005, mainly due to higher oil prices, and is estimated to have remained at about that level in 2006.

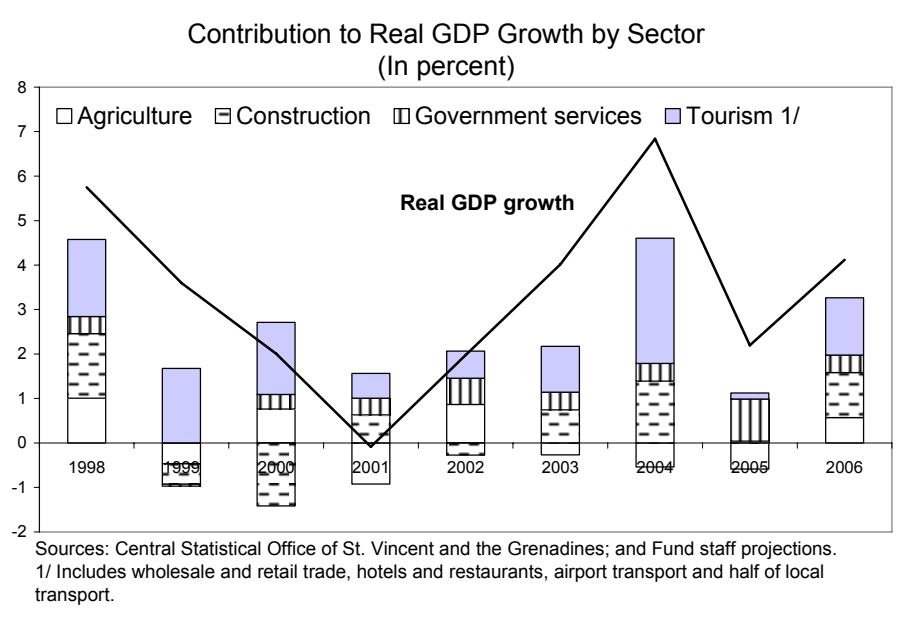

6. Reflecting the effects of the economic slowdown and the electoral campaign, the fiscal position weakened further in $\mathbf{2 0 0 5}$. Revenues performed poorly mainly on account of disappointing consumption tax collections, as well as the effect on petroleum tax receipts of the limited pass-through of international oil prices to domestic petroleum product prices. At the same time, interest payments and transfers to households rose sharply, taking the overall deficit to 5.6 percent of GDP and gross public sector debt to 82 percent of GDP.

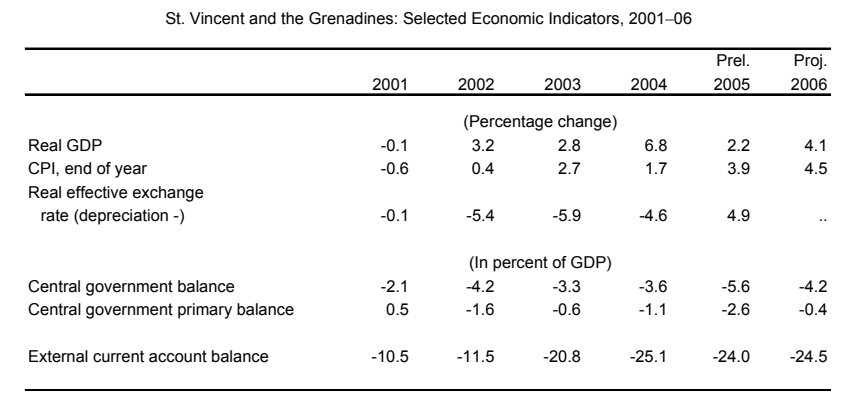

Sources: Ministry of Finance and Planning; and Fund staff estimates and projections.

\section{The 2006 budget attempted to} strengthen the fiscal position, but the situation remains difficult. The main revenue measure was a 43 percent increase in retail gasoline prices from EC $\$ 8$ to EC $\$ 11.5$ per gallon,

\begin{tabular}{|c|c|c|c|c|c|c|c|}
\hline \multicolumn{8}{|c|}{$\begin{array}{l}\text { Summary of Central Government Operations, 2001-06 } \\
\text { (In percent of GDP, unless otherwise stated) }\end{array}$} \\
\hline & 2001 & 2002 & 2003 & 2004 & $\begin{array}{r}\text { Est. } \\
2005\end{array}$ & $\begin{array}{r}\text { Active } \\
2006\end{array}$ & $\begin{array}{l}\text { Current } \\
\text { Policies } \\
200611\end{array}$ \\
\hline Total revenue and grants & 30.7 & 31.7 & 31.3 & 30.0 & 30.5 & 31.1 & 30.8 \\
\hline $\begin{array}{l}\text { Current revenue } \\
\text { Grants }\end{array}$ & $\begin{array}{c}28.7 \\
1.9\end{array}$ & $\begin{array}{c}30.6 \\
1.1\end{array}$ & $\begin{array}{c}30.8 \\
0.4\end{array}$ & $\begin{array}{c}29.2 \\
0.7\end{array}$ & $\begin{array}{c}29.0 \\
1.5\end{array}$ & $\begin{array}{c}29.6 \\
1.4\end{array}$ & $\begin{array}{c}29.3 \\
1.4\end{array}$ \\
\hline Total expenditure and net lending & 32.7 & 34.0 & 34.7 & 33.6 & 36.1 & 35.4 & 37.3 \\
\hline Current & 27.7 & 28.0 & 26.7 & 26.3 & 27.8 & 27.7 & 29.3 \\
\hline Capital expenditure & 5.0 & 6.4 & 7.9 & 7.2 & 8.3 & 7.6 & 8.0 \\
\hline Net lending & 0.0 & -0.4 & 0.0 & 0.0 & 0.0 & 0.0 & 0.0 \\
\hline Current balance (before grants) & 1.0 & 2.6 & 4.1 & 2.9 & 1.3 & 1.9 & 0.1 \\
\hline Overall balance (cash basis) & -2.1 & -4.2 & -3.3 & -3.6 & -5.6 & -4.2 & -6.4 \\
\hline $\begin{array}{l}\text { Of which } \\
\text { Primary balance }\end{array}$ & & & & & & & \\
\hline Primary balance & 0.5 & -1.6 & -0.6 & -1.1 & -2.6 & -0.4 & -2.5 \\
\hline Gross central government debt (in percent of GDP) & 65.5 & 68.3 & 67.8 & 70.4 & 72.1 & 70.8 & 76.9 \\
\hline Public sector debt (in percent of GDP) & 68.2 & 70.5 & 72.3 & 78.1 & 81.6 & 84.5 & 86.7 \\
\hline Debt service as a proportion of current revenues & 14.1 & 14.0 & 14.7 & 19.3 & 21.3 & 24.9 & 25.4 \\
\hline GDP at market prices (EC $\$$ millions) & 933 & 987 & 1,032 & 1,101 & 1,161 & 1,258 & 1,258 \\
\hline
\end{tabular}
implemented in two steps in January and August 2006. At the same time, the government announced a capping of tax concessions at 50 percent of import duties and an expansion of consumption tax / As in the approved budget, except for capital expenditures, for which an execution rate of 50 percent is assumed, payable on a number of previously-exempt activities and products. However, the budget generally avoided expenditure cuts, and a number of large-scale programs and projects were 
started or accelerated, including universal secondary education, the renovation of the cricket stadium (Box 1), a new international airport on the main island of St. Vincent, and construction of a jetport in the Grenadines.

\section{Box 1. St. Vincent and the Grenadines: Economic Impact of the 2007 Cricket World Cup}

The ninth Cricket World Cup (CWC) will be held in the West Indies between March 5 and April 28, 2007, and will be the largest single sporting event held in the region. Organizers expect that close to 800,000 tickets will be purchased during the tournament, with over two billion people worldwide expected to watch the matches on television. St. Vincent and the Grenadines has been chosen as one of the warm-up venues, and will host four matches, including matches between previous CWC champions, Australia and England, in February 2007.

In order to meet the requirements of the $\mathrm{CWC}$, the St. Vincent and the Grenadines authorities are significantly redeveloping the sporting complex at Arnos Vale. The 2006 budget allocated EC\$20 million for this project. In addition to the Arnos Vale Cricket Facility, an initial EC\$5 million is budgeted for a soccer stadium. Additional costs related to security standards and media facilities required for the CWC are likely to be significant.

The economic benefits to St. Vincent and the Grenadines from hosting warm-up games are likely to be less than the cost of redeveloping the sporting facilities. This reflects the fact that St. Vincent and the Grenadines will be hosting only warm-up matches for the tournament, and that the CWC will be played during the peak winter tourism season, so that the additional inbound tourists induced by the CWC may supplant, rather than supplement, the regular tourist economy. Finally, the boost to public expenditure and tourism spending could place upward pressure on the price level and the real exchange rate, adversely affecting the tradables sector of St. Vincent and the Grenadines' economy.

8. Due to difficulties in establishing the institutional and regulatory framework for the value-added tax (VAT), implementation of the VAT has been delayed from January to May 2007. The authorities are making good progress to achieve this revised target date. The VAT implementation unit was established in 2005, and with Fund (FAD, LEG) and CARTAC technical assistance, the authorities prepared (and in February 2006 published) a White Paper that outlined the government's views and policies on the VAT. The government has also completed VAT legislation, which was adopted in October 2006. 
9. St. Vincent and the Grenadines continues to be the main issuer of treasury bills auctioned in the ECCU's Regional Government Securities Market (RGSM). Despite its rising stock of debt, spreads over U.S. treasury bills in 2006 have continued to shrink, possibly reflecting a lack of alternative investment opportunities in the region. ${ }^{1}$

\section{The external current account deficit} narrowed in 2005, yet is likely to expand in 2006. The contraction in 2005 was driven by a slowdown in imports due to the weakening of GDP growth, which more than offset a fall in agricultural exports. In 2006 the current account deficit is expected to widen slightly (to about $24 \frac{1}{2}$ percent of GDP), mainly on account of continued high oil imports

\begin{tabular}{|c|c|c|c|c|c|c|c|}
\hline & 2001 & 2002 & 2003 & 2004 & $\begin{array}{l}\text { Prel. } \\
2005 \\
\end{array}$ & $\begin{array}{l}\text { Proj. } \\
2006 \\
\end{array}$ & $\begin{array}{l}\text { Proj. } \\
2007 \\
\end{array}$ \\
\hline \multicolumn{8}{|c|}{ (Percentage change) } \\
\hline Terms of trade & 2.9 & 2.6 & -4.9 & 0.0 & -4.3 & 0.6 & -2.1 \\
\hline Real effective exchange rate, (depreciation -) & -0.1 & -5.4 & -5.9 & -4.6 & 4.9 & $\ldots$ & $\ldots$ \\
\hline Banana export receipts & -25.4 & 16.0 & -25.2 & 10.0 & -8.9 & 23.3 & -4.7 \\
\hline \multicolumn{8}{|c|}{ (In percent of GDP) } \\
\hline Current account & -10.4 & -11.5 & -20.8 & -25.1 & -24.0 & -24.5 & -24.9 \\
\hline Exports & 50.9 & 48.8 & 45.2 & 45.2 & 44.4 & 45.3 & 44.8 \\
\hline Imports & 60.2 & 58.8 & 63.1 & 66.7 & 64.7 & 65.3 & 65.8 \\
\hline Tourism receipts & 25.8 & 24.9 & 23.8 & 23.4 & 23.5 & 23.4 & 23.9 \\
\hline Oil imports & 4.9 & 4.2 & 5.2 & 6.1 & 7.7 & 7.8 & 7.9 \\
\hline Foreign direct investment (net) & 6.1 & 9.3 & 14.4 & 16.1 & 7.7 & 9.6 & 13.5 \\
\hline Outstanding external debt (end of period) & 49.1 & 46.5 & 50.9 & 54.1 & 54.7 & 53.3 & 50.7 \\
\hline
\end{tabular}
and imports related to private construction and public capital expenditure. The current account is expected to be largely financed by FDI inflows.

11. External competitiveness appears to have improved in recent years (Figure 3). The depreciation of the U.S. dollar against major currencies since end-2001 has helped depreciate the customer-based exchange rate index by 13 percent in real effective terms. Real wage increases have remained modest, and St. Vincent and the Grenadines has steadily increased its share of stayover visitors in the ECCU and the wider Caribbean. Although rising oil prices and flat export prices have caused the terms of trade to deteriorate since 2002, domestic inflation has been contained and the real effective exchange rate does not appear to be misaligned.

\footnotetext{
${ }^{1}$ Since March 2003, St. Vincent and the Grenadines has issued (on a monthly basis) EC\$16 million in 91-day treasury bills. In August 2006, a ten-year bond was issued on the RGSM for EC $\$ 40$ million.
} 


\section{Broad money (M2) growth}

remained strong in 2005, despite the economic slowdown. Bank deposits were used to fund both a surge in net lending to the central government and an expansion in private credit, mainly to households. In 2006, private credit is projected to increase in line with service sector growth, while public sector credit has also risen, due mainly to the funding of several large infrastructure projects.

\section{Prudential indicators point to a} strengthening in the banking sector. Although high government exposures and deposits in the state-owned local bank - the National Commercial Bank (NCB)_remain a potential source of vulnerability, asset quality and capital adequacy improved in 2005 and 2006

(Figure 4). Local banks have significantly reduced nonperforming loans, and an injection
St. Vincent and the Grenadines: Selected Monetary Indicators, 2001-07

\begin{tabular}{|c|c|c|c|c|c|c|c|}
\hline & 2001 & 2002 & 2003 & 2004 & 2005 & $\begin{array}{l}\text { Proj. } \\
2006 \\
\end{array}$ & $\begin{array}{l}\text { Proj. } \\
2007\end{array}$ \\
\hline \multicolumn{8}{|c|}{ (Annual percentage change) } \\
\hline Broad money & 3.0 & 8.3 & 1.9 & 13.7 & 6.4 & 8.3 & 8.9 \\
\hline Credit to private sector & 2.3 & 4.6 & 0.6 & 0.9 & 5.5 & 2.2 & 4.0 \\
\hline \multicolumn{8}{|c|}{ (Percent contribution compared to M2 at the beginning of the year) } \\
\hline Net foreign assets & -4.1 & 2.9 & 5.7 & 15.7 & -4.6 & 1.4 & 1.9 \\
\hline Net domestic assets & 7.2 & 5.4 & -3.9 & -2.0 & 11.0 & 6.9 & 6.9 \\
\hline $\begin{array}{l}\text { Net credit to public sector } \\
\text { Of which }\end{array}$ & 0.3 & 4.8 & -4.0 & 2.7 & 7.6 & 4.9 & 4.2 \\
\hline Central government & -2.9 & 6.4 & -5.5 & -5.7 & 8.3 & 4.6 & 4.6 \\
\hline Credit to private sector & 2.1 & 4.3 & 0.6 & 0.8 & 4.3 & 1.7 & 2.9 \\
\hline Net credit to nonbank financial inst. & -3.5 & 0.9 & -0.3 & 4.5 & -1.1 & 0.5 & -0.2 \\
\hline Other items (net) & 8.3 & -4.6 & -0.2 & -10.0 & 0.3 & -0.1 & 0.1 \\
\hline
\end{tabular}

Sources: St. Vincent and the Grenadines authorities, ECCB and Fund staff estimates.

of capital from a foreign parent bank to its local subsidiary improved system capital adequacy.

\section{There has been limited progress toward strengthening the financial sector} supervisory and regulatory framework since the 2004 ECCU regional FSAP. The FSAP recommended: a uniform Banking Act to strengthen the regulatory and supervisory authority of the ECCB (yet to be passed by Parliament); more frequent and timely onsite inspections (to be carried out by the ECCB); and implementation of non-zero risk weighting for government and public sector obligations. Only the latter measure has been adopted (in December 2005). ${ }^{2}$ Following the passage of the International Bank Act in December 2004, there has been a strengthening of regulation and supervision of the offshore banking sector. ${ }^{3}$ Guidelines for prudential requirements for offshore banks, consistent with Basel Core Principles, have been drafted and are expected to be issued in the first quarter of 2007.

\footnotetext{
${ }^{2}$ Under the new guidelines, banks apply a 20 percent risk weight to nonperforming public sector exposures and charge 10 percent of the amount of nonperforming exposures as loan loss provision.

${ }^{3}$ Activity in the offshore sector continues to expand. As of August 2006, the St. Vincent and the Grenadines' offshore sector comprised: 7 offshore banks, 6,177 international business companies, 99 international trusts, 13 insurance companies, and 29 mutual funds - all are regulated by the International Finance Service Authority (IFSA).
} 


\section{Policy Discussions ${ }^{4}$}

\section{A. Overview}

15. The principal economic challenge facing the country is to find new sources of sustainable growth without compromising fiscal and debt sustainability. Although there is a need to improve air transport links to boost and diversify tourism, the public debt stock is already too high, constraining expenditure on poverty-reduction and social programs and reducing the fiscal room for maneuver in the event of an adverse exogenous shock. Therefore, given relatively limited fiscal space to undertake high-cost capital projects, staff cautioned against the planned acceleration in capital expenditure. Accordingly, the discussions were organized around three key areas:

- $\quad$ Raising medium-term growth prospects, including by developing new sources of growth away from the declining banana industry towards tourism.

- $\quad$ Reinforcing fiscal policy and ensuring debt sustainability, through measures to increase revenue, and cuts in the wage bill and public investment program.

- $\quad$ Responding to adverse shocks, in particular the erosion of banana trade preferences and the country's proneness to natural disasters.

16. The authorities generally agreed with the mission's recommendations, but placed a greater weight on the need for fiscal policy to support social needs and the build-up in national transportation infrastructure. In particular they agreed on the importance of medium-term fiscal consolidation, including by adjustment of domestic fuel prices and the introduction of the VAT. However, the authorities also underscored that expenditure would need to rise in the near term on education, health, and public infrastructure, to facilitate the transition of the economy from agriculture to tourism.

\section{Dialogue between Fund staff and the authorities continues to deepen. The} authorities considered the mission's policy recommendations to be useful, particularly the detailed fiscal policy recommendations provided on this and previous Article IV consultations. The government has been receptive to Fund advice, particularly in bolstering revenues through the raising of domestic petroleum prices and implementation of the VAT and market-valuation based property taxes. However, there has been less responsiveness to the mission's recommendations to rein in social and capital expenditures.

\footnotetext{
${ }^{4}$ The discussions were complemented by the 2006 Eastern Caribbean Currency Union (ECCU) regional discussions, the report for which covers common regional issues related to monetary and exchange rate issues and banking system supervision.
} 


\section{B. Enhancing Growth Prospects}

18. Raising the country's growth potential will be a challenge. Bananas have ceased to be a major contributor to the country's economy and tourism is at present largely limited to several high-end hotels in the Grenadines, with very few large hotels on the main island. The tourism industry is constrained by limited international air transportation links, and the relatively high cost of capital and labor. The mission suggested that strong reforms (outlined below) would help the economy achieve medium-term growth of 4-5 percent a year. The authorities, however, considered the staff's estimates as overly cautious, arguing that mediumterm growth could average close to 6 percent per year, given a successful transition from agriculture to a tourism- and services-based economy. ${ }^{5}$

\section{Discussions centered on four key structural reform priorities.}

- $\quad$ Tourism and international air transportation. Although there is a need to improve international air transport links to develop the country's tourism potential, staff stressed the need for grants and highly concessional financing for the bulk of the projects. In particular, the mission welcomed the authorities' plans to mobilize donor assistance for the proposed new airport at Argyle, which is expected to cost EC $\$ 480$ million (about 40 percent of 2005 GDP), over the period 2006-11 (Box 2). ${ }^{6}$ However, the mission still suggested that an updated economic feasibility study was needed for the project, given its cost and potential impact on the country's debt position.

- $\quad$ Strengthen the investment climate. In line with other ECCU countries, private domestic investment has stagnated in recent years, mainly as a result of high real interest rates, the lack of opportunity for equity finance, and a tax regime that is overburdened with tax incentives. The mission called for a more transparent framework for providing incentives, that more effectively favored new investment, possibly involving accelerated depreciation and loss carry-forward provisions. This could permit a gradual lowering of the corporate income tax rate-which presently is paid by only those companies not benefiting from tax concessions - from 40 to 30 percent. Further enhancements to the publicly-owned, one-stop investment agency (National Investment Promotions, Incorporated) would also help strengthen the climate for both foreign and local direct investment.

\footnotetext{
${ }^{5}$ The authorities continue to promote economic diversification through: the European Union (EU)-funded Agriculture Diversification Program, enhancing links between agriculture and tourism, and developing the fishing industry and greater food processing.

${ }^{6}$ At present, the country does not have an international airport that allows access for medium-haul jet aircraft. The government has also commenced construction of Canouan Island jetport (at a cost of EC\$60 million) in the Grenadines.
} 


\section{Box 2. St. Vincent and the Grenadines: International Airport Project and Financing}

The proposed international airport on the main island of St. Vincent has been under discussion for more than two decades, despite several estimates suggesting that the project is economically unviable. The Canadian consulting firm Marshall Macklin Monaghan (MMM) completed the most recent comprehensive airport study in September 1998, and argued against building a new airport and concluded that the only economically viable option was a limited renovation of the existing airport at ET Joshua.

In 2005, the government decided to go ahead with the new airport at Argyle - the estimated total cost is about US\$178 million (40 percent of the country's 2005 GDP) - without further cost-benefit analysis. In November 2004, the government established the International Airport Development Corporation (IADC), a fully government-owned company to facilitate financing, construction, and operation of the airport. The decision to go ahead with the project without further cost-benefit analysis was based on the view that further analysis was not needed given the government's efforts to achieve grant rather than commercial funding for the project.

The proposed financing plan has two pillars: bilateral official assistance and the sale of state-owned lands. Bilateral official assistance would be provided mostly in grants. Cuba and Venezuela are expected to provide a considerable amount of assistance in kind in respect of earthwork and airport designs. In addition, Taiwan Province of China would provide grants and loans, and the Malaysian Airport Authority would provide equity investment. The second pillar - the sale of state-owned lands - would be used mainly to finance land acquisition at Argyle. The government has vested over 800 acres in the IADC as its equity, including prime lands in Bequia and Buccament. According to preliminary estimates, these lands are worth more than EC \$270 million (US\$100 million) in total; a part of them would be sold through the IADC's real estate agent, the National Properties Ltd. The IADC has obtained bridging loans from National Insurance Services and a Trinidad bank while the sale of the state-owned lands takes place.

This large-scale public-led investment raises a number of concerns. First, there has not been any updated cost-benefit analysis since 1998. Relatedly, there has not been an update of the market analysis, which can be crucial in determining demand for use of the airport. Also, the cost effectiveness of the project has not been compared with alternative methods of improving air access, for example, improving the shuttle system between the existing airport and neighboring island countries. Second, there are considerable uncertainties related to the grants in kind, for which there do not seem to be formal written agreements. Lastly, the possibility of publicprivate partnership, as an alternative to traditional public investment, has not been fully explored - at this stage, the government intends to seek private investment only if there is a need to fill any financing gap.

- $\quad$ Enhanced regional integration. Although St. Vincent and the Grenadines has relatively good governance indicators, the mission encouraged the authorities to take advantage of regional integration to reduce business costs (Figure 5). In this context, there is scope for St. Vincent and the Grenadines to enhance implementation of the Caribbean Community (CARICOM) Single Market and Economy (CSME) requirements, and to continue to push for free labor movement within CARICOM. There was also merit in improving regional cooperation in the provision of collective government services and the granting of tax concessions, and supporting regional efforts to increase the flexibility of the movement of goods, labor and capital across Organization of Eastern Caribbean States (OECS) countries. The authorities stated that St. Vincent and the Grenadines (in common with other OECS countries) had initially been reluctant to agree to the CSM on the original timetable of January 2006, 
as they felt there were few gains from trade available to disadvantaged regions (such as the OECS), given the domination of intra-CARICOM trade by Trinidad and Tobago and other larger Caribbean countries. Accordingly, St. Vincent and the Grenadines had been a leading proponent of a regional fund to finance development expenditures for all CARICOM countries. Once this fund was established, St. Vincent and the Grenadines (in common with other OECS countries) signed on to the CSM in June 2006, and looked forward to drawing upon the associated Regional Development Fund (RDF), to finance social and infrastructure expenditures. ${ }^{7}$

\begin{tabular}{lcccccc}
\multicolumn{7}{c}{ ECCU: Doing Business Indicators, 2006} \\
\hline & $\begin{array}{c}\text { Antigua \& } \\
\text { Barbuda }\end{array}$ & Dominica & Grenada & $\begin{array}{c}\text { St. Kitts \& } \\
\text { Nevis }\end{array}$ & St. Lucia & $\begin{array}{c}\text { St. Vincent } \\
\text { \& Grens. }\end{array}$ \\
\hline Starting a business & 22 & 24 & 50 & 105 & 43 & $\mathbf{2 9}$ \\
Registering property & 71 & 78 & 145 & 136 & 51 & $\mathbf{1 0 1}$ \\
Getting credit & 101 & 101 & 83 & 117 & 101 & $\mathbf{8 3}$ \\
Enforcing contracts & 47 & 159 & 143 & 135 & 160 & $\mathbf{1 2 5}$ \\
Paying taxes & 145 & 20 & 45 & 116 & 9 & $\mathbf{3 2}$ \\
Closing a business & 54 & 151 & 151 & 151 & 39 & $\mathbf{1 5 1}$ \\
Protecting investors & 19 & 19 & 19 & 19 & 19 & $\mathbf{1 9}$ \\
Trading across borders & 47 & 97 & 84 & 37 & 45 & $\mathbf{4 8}$ \\
Dealing with licenses & 15 & 51 & 12 & 7 & 10 & $\mathbf{1}$ \\
Employing workers & 40 & 50 & 34 & 35 & 29 & $\mathbf{4 8}$ \\
Overall ranking & 33 & 72 & 73 & 85 & 27 & $\mathbf{4 4}$ \\
\hline
\end{tabular}

Source: World Bank, "Doing Business."

Note: Ranking out of 175 economies, where 1 is most conducive and 175 is least conducive.

- $\quad$ Better leveraging benefits from migration. More than a quarter of the labor force of St. Vincent and the Grenadines emigrated to OECD countries in the period 19702000. This large-scale emigration has produced a steady flow of remittances from Vincentians abroad. The mission suggested that there was scope to boost the growth potential of remittances, including through the reduction of regulatory barriers that discourage remittance flows and investment by returning nationals. The authorities broadly concurred with the staff's recommendations and intended to continue to enhance links with the country's large diaspora.

\section{Debt Sustainability and Fiscal Policy}

20. Staff cautioned that measures announced in the $\mathbf{2 0 0 6}$ budget were insufficient to put the country on a sustainable debt path. This is mainly because the budget focused on only revenue measures (the VAT and a one-time increase in petroleum prices), which were more than offset by a surge in outlays. Looking forward, the staff estimated that absent strong fiscal adjustment, public debt would reach 107 percent of GDP by 2011, well above the 75 percent of GDP specified in the government's Debt Strategy. This would boost central government debt servicing to more than 8 percent of GDP (about 28 percent of current

\footnotetext{
${ }^{7}$ The CSM's RDF is to take effect from July 2007, and will provide financial and technical assistance to disadvantaged regions and countries. The RDF will commence with an initial capitalization of US\$130 million, to be contributed jointly by member states (St. Vincent's contribution will be US $\$ 1.64$ million).
} 
revenues), raise the government's vulnerability to rollover risk, and constrain its ability to undertake poverty alleviating expenditures.

\section{Against this background, the mission recommended the adoption of a front-}

loaded fiscal adjustment. On the basis of an active scenario involving additional fiscal measures, an increase in grant financing, and medium-term real GDP growth of the order of 4-5 percent, the stock of public debt could decline to 76 percent of GDP over the next six years (Annex I).

\section{The mission recommended achieving a primary deficit of 0.4 percent of GDP for} 2006, with further consolidation over the medium term. The adjustment in 2006 (which would be around 2 percent of GDP) could be achieved from the revenue side, mainly through increased petroleum taxes (as a result of the more frequent pass-through of international oil price changes), more vigorous collection of company income tax, and additional capital revenue (derived from land sales). ${ }^{8}$ This would bring the tax collection effort, which had lagged in 2004-05, in line with levels attained in previous years. In order to accommodate planned capital expenditures while ensuring fiscal adjustment, stricter discipline was needed on current expenditures, mainly on wages and salaries. The mission urged a further fiscal adjustment of about 1.2 percent of GDP in 2007, achievable by a range of measures discussed below, taking the central government primary surplus to 0.8 percent of GDP.
St. Vincent and the Grenadines:

Public Sector Debt Dynamics (In percent of GDP)
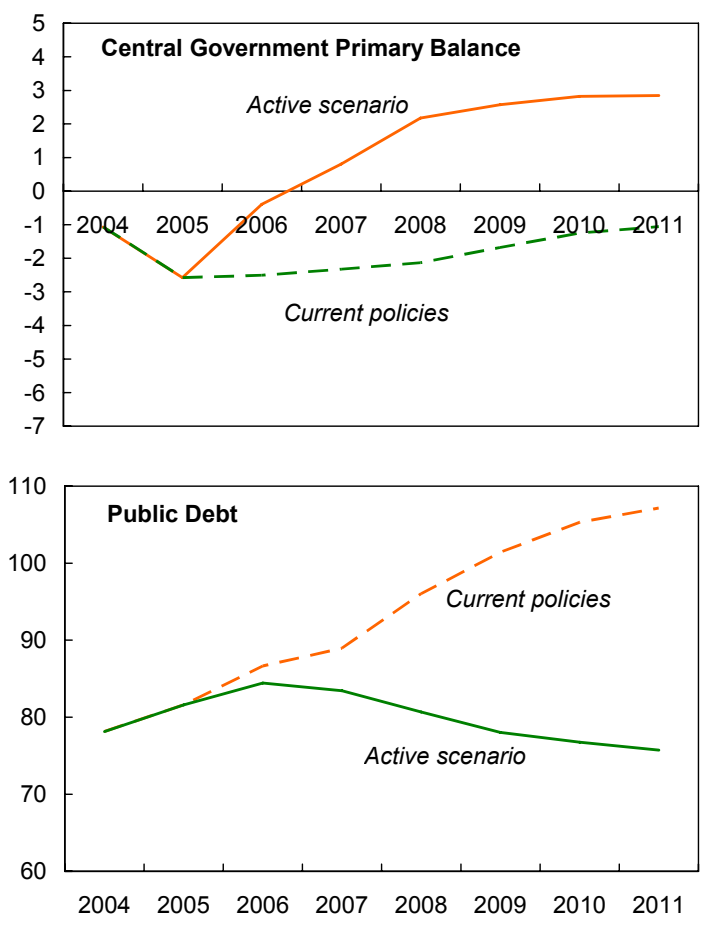

St. Vincent and the Grenadines: Yield from Additional Fiscal Measures (2007-11)

\begin{tabular}{lcc}
\hline & $\begin{array}{c}\text { In EC\$ } \\
\text { million }\end{array}$ & $\begin{array}{c}\text { In percent } \\
\text { of GDP }\end{array}$ \\
\hline $\begin{array}{l}\text { (Average yield per year) } \\
\text { Revenue and grants }\end{array}$ & $\mathbf{2 6}$ & $\mathbf{1 . 6}$ \\
$\begin{array}{l}\text { VAT (assuming increase in compliance rate } \\
\text { and uniform rate of 15 percent) }\end{array}$ & 16 & 1.0 \\
$\begin{array}{l}\text { Property tax reform (move to market } \\
\text { valuation and higher compliance) }\end{array}$ & 5 & 0.4 \\
Grants & 4 & 0.2 \\
Expenditure & $\mathbf{2 5}$ & $\mathbf{1 . 6}$ \\
Wage savings (assuming constant real & 15 & 0.9 \\
wage bill) & 10 & 0.7 \\
\hline Prioritization of capital expenditures & & \\
\hline
\end{tabular}

Source: Fund staff estimates.

23. In the wake of policy changes following the mission, the authorities appear likely to achieve a fiscal position close to that of the active scenario for 2006. Effective August 21, 2006, retail prices of gasoline and diesel were raised by 20 and 3 percent,

\footnotetext{
${ }^{8}$ The taxation authorities estimate that there are up to about EC $\$ 90$ million in uncollected taxes, mainly due to insufficient enforcement.
} 
respectively. Expenditure on wages and salaries has also been constrained in the third quarter of 2006.

\section{Staff commended the authorities on their preparations for introduction of the}

VAT. The revised target implementation date (May 1, 2007) appears feasible, and with the planned single VAT rate of 15 percent, the tax is likely to be revenue positive (yielding about 1 percent of GDP in additional revenues). ${ }^{9}$

\section{Staff urged the authorities to stand firm against pressures to increase the list of products and services exempted (or zero-rated) under the VAT. Yielding to these} pressures would increase the administrative burden, erode the tax base, distort incentives in the tax regime, and complicate compliance. Staff also commended the authorities on their active engagement with the IMF and CARTAC to obtain the technical assistance needed for VAT establishment and implementation.

\section{Over the medium term, there is scope to raise revenues by broadening the coverage of the tax system. Key aspects include:}

- Property tax. Property tax collections do not seem to be keeping pace with real estate prices. Staff encouraged the government to move to a market valuation-based property tax system as soon as technically feasible, and to complete the required cadastral surveys as an important first step. The authorities agreed with this recommendation, and plan to revise the property tax system during 2008, following introduction of the VAT.

- Taxation of petroleum products. At present

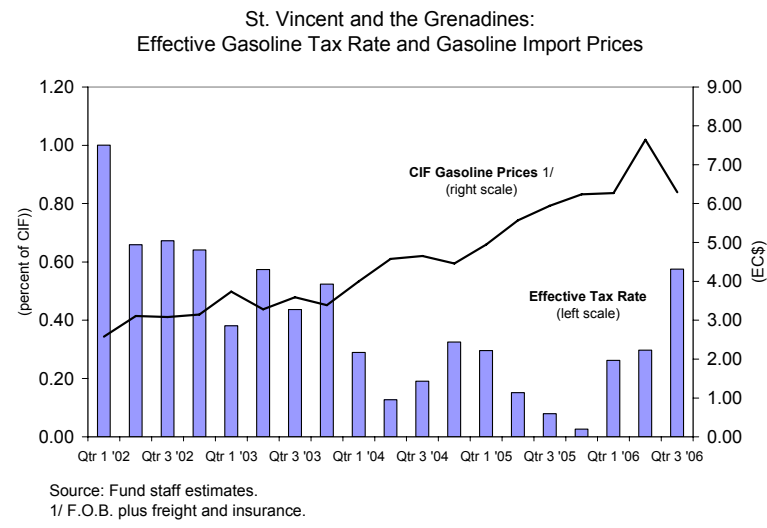
there is a legislated consumption tax, but in recent years the government has been absorbing most of the additional cost of higher world oil prices, thereby eroding revenues. The mission urged the adoption of a flexible pricing mechanism. While the authorities broadly agreed with the staff's advice, they argued that they preferred to maintain a system of discrete price 1/ F.O.B. plus freight and insurance. adjustments to enable them to smooth out the impact on the poor, who rely more heavily on cooking fuel and public transportation.

\footnotetext{
${ }^{9}$ The VAT Act was passed by Parliament in October 2006, and envisages a single VAT rate of 15 percent applied to goods and services; tourist accommodations will have a rate of 10 percent. Many basic items have been zero-rated (such as bulk rice, flour and sugar) or exempted (such as publicly-supplied water and prescription drugs) from VAT.
} 
- Reducing tax concessions. Tax competition is severe in the region, and St. Vincent and the Grenadines has extensive tax concessions, both for corporate and customsrelated taxes, which result in a loss of revenue of about 10 percent of GDP. The authorities stated that they were committed to reducing discretionary concessions, but that a certain level of statutory concessions was needed to attract foreign direct investment.

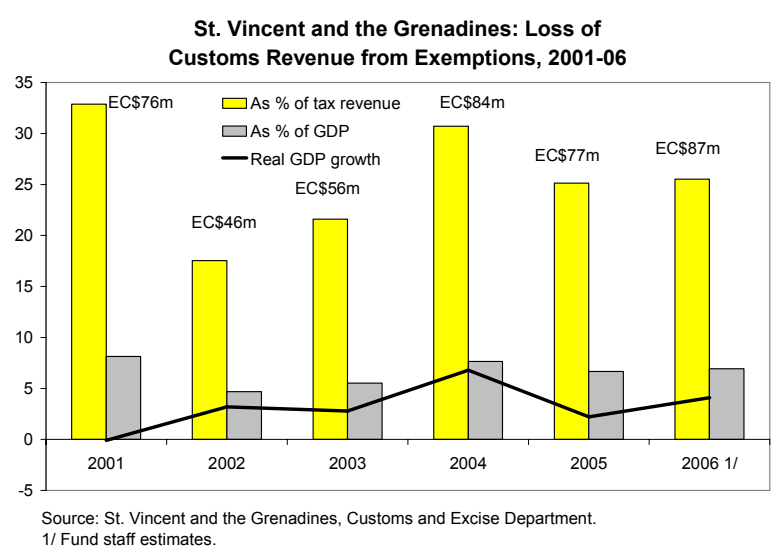

\section{Staff stressed that addressing St. Vincent and the Grenadines' fiscal imbalances} required stricter spending discipline. There are several key components of expenditures where reductions can be made:

- Prioritization of the capital budget. Greater prioritization of capital expenditures would enhance the efficiency of public sector investments. The 2006 budget includes provisions for a large number of new, high-profile projects - many without adequate cost-benefit analysis - including the new international airport on the main island, the jetport in the Grenadines, sport facility renovation, and road construction. Better efforts were needed to prioritize and properly phase infrastructure projects, and fund these with grant financing and concessional loans. Staff urged that the government use Caribbean Development Bank and World Bank expertise to evaluate the efficacy of all public sector investment program (PSIP)-listed projects above a certain threshold (e.g., EC\$5 million), and to upgrade the PSIP, with technical assistance from CARTAC.

- Public sector wages and employment. The government's wage bill, which accounts for about half of all current expenditures, is among the highest in the ECCU. The mission recommended that growth in the number of civil servants be strictly limited and wage increases be prudently managed, by initiating civil service reform aimed at reducing employment levels and providing greater differentiation in the pay scale between higherand lower-skilled workers. The authorities argued that the country's wage bill was not excessive. They pointed out that the delivery of government services across a multi-island country was very costly. 
- Social security reforms. The financial position of the country's social security scheme, National Insurance Services (NIS), is weak, and there is a need for fundamental reforms (Box 3). Population ageing and the maturing of the scheme will require steep increases in expenditure in the medium term that will not be covered by contributions and accumulated NIS assets. The mission suggested consideration of a range of options, including: increasing the contribution rate for social security pensions; gradually raising the

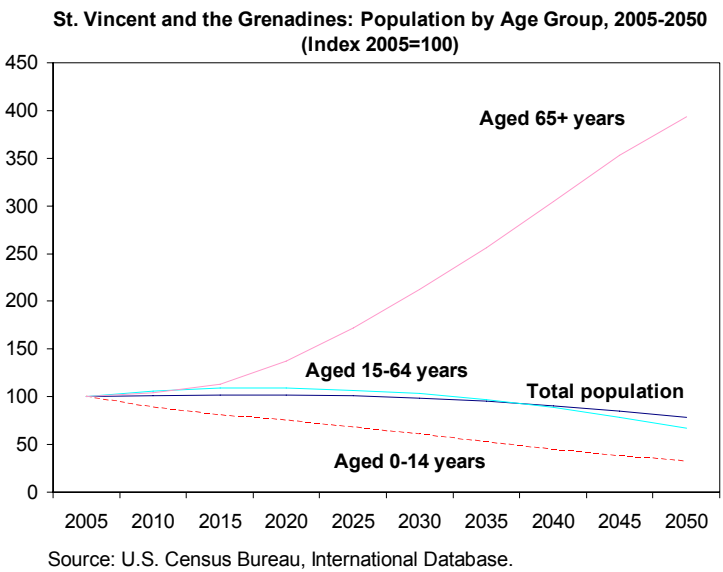
retirement age from 60 to 65; and eliminating the duplication of pensions (by capping the combined benefits from civil service and social security pensions). The authorities agreed that it was important to quickly tackle the challenges facing the NIS, and undertook to examine further the staff's proposals. The authorities also stated that they have agreed in principle to a gradual increase in the contribution rate from 6 percent to 10 percent. They also supported the establishment of an OECS pension reform commission, that would examine pension-related issues in all OECS countries.

\section{Social programs have evolved in a piecemeal fashion, and are expensive and}

poorly targeted (Box 4). The mission welcomed the government's announcement that a household survey and poverty assessment would be undertaken in 2007, and suggested that these results should be used to improve the targeting of social benefits and to develop transparent criteria for their provision.

29. Staff recommended that the government's Debt Strategy be strengthened. The Strategy targets a medium-term debt level of 75 percent of GDP, to be achieved mainly by restructuring of Ottley Hall debt (11/1/2 percent of GDP at end-2005). ${ }^{10}$ The mission stated that this target would still leave the fiscal position vulnerable, given the growing cost of debt servicing, the declining concessionality of public borrowings, and the volatility of national income and export receipts. The authorities were more optimistic, and viewed the target as achievable and a useful benchmark for fiscal policy. They also anticipated a reversal of the

\footnotetext{
${ }^{10}$ In 1999 the government assumed a large private external debt of EC $\$ 156$ million (amounting to a then $17 \frac{1}{2}$ percent of GDP) for the construction of Ottley Hall shipyard (a yacht repair facility). The shipyard was operated by a joint-venture company, Caribbean Charter and Yacht Yard Holdings, owned by the government (49 percent) and a private company, the St. Vincent Yachting and Shipping Company (51 percent). The government had guaranteed the debt. In 2001 the government obtained a moratorium on interest payments pending a settlement with creditors (foreign commercial banks), and continues to seek a debt restructuring. The Italian export guarantee agency, SACE, which insured the external financiers, continues to service the loan. The government has clearly indicated that in reaching any agreement with creditors to write down the debt, it would not pay more for the debt than the value of the Ottley Hall assets (valued in 2005 at about EC\$15 million).
} 
public debt ratio, once the much-needed near-term boost to social and infrastructure spending was complete.

\section{Box 3. St. Vincent and the Grenadines: Long-term Solvency of the National Insurance Services (NIS) and Its Role in the Economy ${ }^{1}$}

\section{St. Vincent and the Grenadines' National Insurance Services (NIS) faces major challenges. Its 2005 Actuarial Review projected that after 2012, contributions collected will not be sufficient to cover expenses. This will lead to a decreasing net income and consequently a depletion of the fund's reserves. Estimates of the net present value of future income and expenditure streams show a net implicit liability equivalent to 12 percent of GDP. Furthermore, it is estimated that in a 60-year horizon the implicit liability would be close to 100 percent of GDP.}

To ensure the financial soundness of the scheme, it is estimated that the NIS would have to almost double the contribution rate to at least 11 percent of insurable earnings (IE) within the next five years. Currently St. Vincent and the Grenadines has the second-lowest contribution rate in the Caribbean- 6 percent of IE. Other reforms to assist the finances of the NIS could include: raising the retirement age; streamlining benefits (including reducing overlap with civil service pensions); and altering investment portfolios.

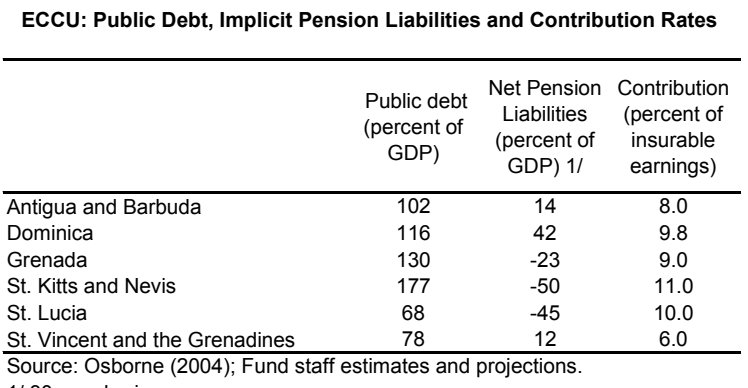

$1 / 30$ year horizon.

The NIS is also an important part of the country's financial system. Due to the relative youth of the St. Vincent and the Grenadines' population, the NIS has accumulated reserves in excess of 20 percent of GDP, which have been mostly invested in domestic public assets (such as government bonds) or deposited at local banks. ${ }^{2}$ While limits on foreign asset allocations of NIS reserves may have contributed to the development of domestic financial markets, it also poses important risks. The growth of NIS reserves in the context of limited local instruments for investment and restrictions on investment overseas may have created distortions in domestic financial markets, including by artificially lowering borrowing costs for the government.

As a result, both sides of the balance sheets of local banks are dominated by the public sector. NIS reserves account for around 20 percent of bank deposits, while close to 25 percent of bank lending is to the public sector. This leaves local banks highly exposed to the public sector and without adequate diversification in their portfolios, particularly in an economy vulnerable to exogenous shocks. Finally, the resulting dominance of shortterm fixed income investments also implies that assets are a very poor match for liabilities. ${ }^{3}$ The duration of NIS portfolios is much shorter than its long-term liabilities. As a result, changes in interest rates may exacerbate assetliability mismatches.

${ }^{1}$ This box draws on T. Rasmussen and S. Roache (2006), "Social Security in the Eastern Caribbean Currency Union," Chapter IV of Eastern Caribbean Currency Union: Selected Issues, forthcoming.

${ }^{2}$ More than 95 percent of NIS reserves are invested in domestic assets.

${ }^{3}$ As of June 2006, 50 percent of NIS reserves were invested in short-term assets. 


\section{Responding to Adverse Shocks}

30. Staff urged the authorities to continue efforts to mitigate the risks related to the National Commercial Bank (NCB). ${ }^{11}$ During 2005 and thus far in 2006, the NCB significantly reduced its nonperforming loans (NPLs), mainly through sales to a publiclyowned asset recovery company (ARC). ${ }^{12}$ Staff observed that it was unusual that these sales had been financed by loans from the NCB, but welcomed the ARC's resolution of these NPLs. Staff also noted the plans for merging the Development Bank and the NCB, and encouraged further efforts to strengthen the NCB's balance sheet and improve its management structure and internal controls.

\section{Staff recommended that greater efforts be taken to address the weaknesses} identified in the 2004 ECCU Regional FSAP report. Approving the uniform Banking Act would be a key step in this regard, since it would help foster a strong and sound banking system capable of supporting growth. While nonbank financial institutions (NBFIs) - the building society, credit unions, the insurance sector, and the Development Bank-are smaller in size (although the St. Vincent and the Grenadines Building Society is of systemic importance to the domestic financial sector), their regulation and supervision needed strengthening. ${ }^{13}$ Staff commended the authorities for their plans to consolidate regulation of insurance companies (presently regulated by the Ministry of Finance and Planning) and offshore financial institutions (IFSA) under a single agency. The mission also welcomed approval of the Money Services Business Act, which became operational in April 2006, and improves accounting and registration of money transfer institutions. The authorities committed to approve the uniform Banking Act in the final quarter of 2006.

\footnotetext{
${ }^{11}$ St. Vincent and the Grenadines' banking system consists of two locally-incorporated banks and two foreign bank branches, and the NCB accounts for about 40 percent of total banking system assets.

${ }^{12}$ In FY 2004-05 the NCB sold (at a discount to face value) about 40 percent of its NPLs to an ARC, to which it extended a loan to finance the purchase. The ARC subsequently recovered sufficient proceeds from the NPLs to fully repay the NCB loan. While the profitability of local banks dipped in 2004, it has since rebounded (Figure 4).

${ }^{13}$ The St. Vincent and the Grenadines Building Society and the Development Bank account for about 8 percent and 1 percent of financial system assets, respectively.
} 


\section{The current high level of international oil prices has placed a significant strain on} the economy, and the authorities have explored alternate sources of energy. Staff noted that implementation of the PetroCaribe Agreement with Venezuela (which commenced in September 2005) has provided some concessional financing of energy imports (LPG cylinders and diesel). Using grant financing from Venezuela, the authorities are in the process of establishing a joint venture company to construct government-owned gasoline storage facilities, enabling the importation of gasoline under the PetroCaribe Agreement. The joint venture company will then pay 60 percent of the value of gasoline imports, with the remainder financed by a concessional loan from Venezuela. The authorities intend to deposit the proceeds from PetroCaribe concessional financing in a sinking fund (consisting of interest-bearing

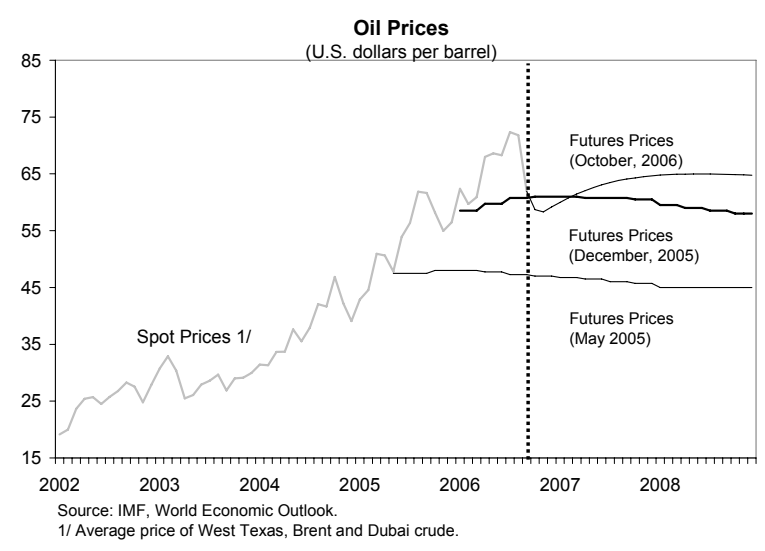
assets), and plan to allocate the interest differential between earnings from the sinking fund and PetroCaribe debt service obligations for social spending.

33. The erosion of trade preferences for bananas has reduced incomes and employment prospects for poor rural

households. Banana producers are facing a difficult future following the conversion of EU quotas into tariffs in January 2006, as free market banana prices are typically considerably below those available in protected EU markets. ${ }^{14}{ }^{15}$ As farmers have limited alternative employment opportunities,

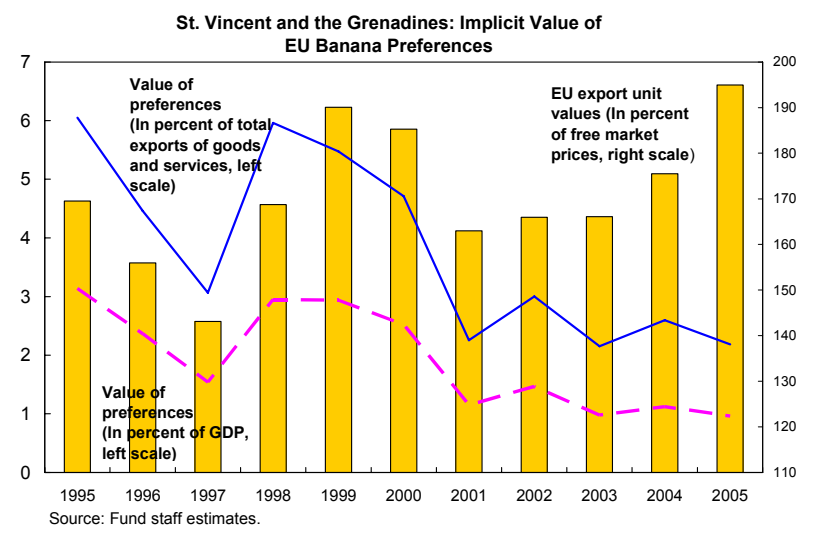
staff supported the provision of well-targeted social safety nets, including the authorities' use of transition measures such as income transfers, retraining programs, noncontributory pensions, and limited subsidies on agricultural inputs (to encourage diversification into nonbanana agriculture). However, the mission stressed the need for a transparent mechanism

\footnotetext{
${ }^{14}$ The EU has proposed a quota-equivalent tariff of $€ 176$ per tonne on non-ACP (Caribbean, African and Pacific) bananas. The new banana regime also includes a duty-free quota of 775,000 tonnes for ACP bananas. While the conversion of quotas into tariffs will afford some protection to ACP-banana exporting countries, St. Vincent and the Grenadines is likely to face strong competition from more efficient African ACP producers.

${ }^{15}$ Beginning in 2006, banana production in St. Vincent and the Grenadines had largely switched from conventional exports to fair trade exports - the price premia on the latter had enabled average export returns in 2006 to broadly remain at pre-2006 levels. See Chapter II of Eastern Caribbean Currency Union: Selected Issues for a discussion of the nature and impact on St. Vincent and the Grenadines of EU preference erosion.
} 
for funding these programs - instead of the current practice of using high retail prices of sugar imported by a public monopoly as the chief funding source - and for the consolidation of poverty-reduction programs (Box 4).

\section{The European Union (EU) is planning to disburse up to about $€ 11.5$ million} during 2006-08, in an effort to assist the transition of the economy away from bananas. This assistance would be mainly in the form of budget support, and is contingent on the development of a reform program. The staff suggested that the macroeconomic framework and reform priorities described above would provide a useful basis for the EU's budget support.

35. The authorities generally agreed with the mission's recommendations on easing the transition of the economy from agriculture to tourism, but lamented the lack of donor support.

The authorities stated that donor financing for investment in health, education and social spending had fallen sharply, just at the time it was most needed. This lack of donor support had then necessitated increased borrowing, often on commercial terms, to

\begin{tabular}{lccc}
\multicolumn{4}{c}{ St. Vincent and the Grenadines: EU Banana Support } \\
\hline & $\begin{array}{c}\text { Amount } \\
\text { Committed }\end{array}$ & $\begin{array}{c}\text { Amount } \\
\text { Disbursed }\end{array}$ & $\begin{array}{c}\text { Percentage } \\
\text { Disbursed }\end{array}$ \\
\hline Special Framework of & \multicolumn{2}{c}{ (In $€$ million) } & (In percent) \\
Assistance & 6.2 & 4.5 & 72.5 \\
1999 & 6.5 & 0.4 & 5.6 \\
2000 & 6.4 & 0.0 & 0.0 \\
2001 & 6.1 & 1.2 & 19.7 \\
2002 & 5.6 & 0.2 & 3.6 \\
2003 & 5.3 & 0.0 & 0.0 \\
2004 & 4.5 & 0.0 & 0.0 \\
2005 & 3.9 & 0.0 & 0.0 \\
2006 & $\mathbf{4 4 . 6}$ & $\mathbf{6 . 3}$ & $\mathbf{1 4 . 1}$ \\
Total &
\end{tabular}

Source: Delegation of the European Commission, Barbados finance these much-needed transitional expenditures.

\section{St. Vincent and the Grenadines is one of the most disaster-prone countries in the} world. Staff encouraged the authorities to further enhance the country's disaster preparedness mechanisms, and welcomed progress on enhancements to disaster management, following passage of the Disaster Management Act in June 2006. The National Emergency Response Plan is presently being revised, and while the National Building Code has been introduced, greater efforts are needed to ensure enforcement of the Code. Insurance of government assets could also be improved, as at present Worldwide Incidence of Natural Disasters, 1970-2005

\begin{tabular}{|c|c|c|c|c|c|}
\hline & \multicolumn{5}{|c|}{ All Recorded Disasters } \\
\hline & \multirow{2}{*}{$\begin{array}{l}\text { Number } \\
\text { of Events }\end{array}$} & \multicolumn{2}{|c|}{$\begin{array}{l}\text { Number of Events } \\
\text { Divided by } \\
\text { Land Area } \\
\end{array}$} & \multicolumn{2}{|c|}{$\begin{array}{c}\text { Number of Events } \\
\text { Divided by } \\
\text { Population }\end{array}$} \\
\hline & & Index & Rank & Index & Rank \\
\hline All countries & 7,963 & 100 & 93 & 100 & 93 \\
\hline Advanced economies & 1,601 & 10 & 103 & 37 & 113 \\
\hline Caribbean & 272 & 631 & 23 & 400 & 29 \\
\hline ECCU & 50 & 784 & 7 & 786 & 7 \\
\hline Antigua and Barbuda & 7 & 679 & 7 & 717 & 6 \\
\hline Dominica & 9 & 512 & 12 & 1,037 & 3 \\
\hline Grenada & 6 & 753 & 5 & 467 & 11 \\
\hline St. Kitts and Nevis & 7 & 829 & 4 & 1,210 & 2 \\
\hline St. Lucia & 9 & 619 & 10 & 451 & 12 \\
\hline St. Vincent and the Grenadines & 12 & 1,312 & 2 & 836 & 5 \\
\hline Other Caribbean & 222 & 540 & 34 & 168 & 43 \\
\hline Other & 6,090 & 55 & 98 & 77 & 96 \\
\hline
\end{tabular}
only a small fraction of public buildings and assets are covered. The staff also welcomed the government's continued participation in regional initiatives (such as the World Bank's Catastrophe Risk Insurance Facility) designed to pool insurance risk across Caribbean countries, and thereby lower the cost of catastrophe insurance. 


\section{Box 4. St. Vincent and the Grenadines: Poverty Reduction Strategy}

There is a dearth of timely and extensive poverty data for St. Vincent and the Grenadines. The most recent source of statistical data on the incidence of poverty in St. Vincent and the Grenadines is "The Poverty Assessment Report" prepared by consultants in 1996. The report states that $371 / 2$ percent of the population (31 percent of households) is below the locally-defined poverty line, and 26 percent of the population (20 percent of households) is indigent. A study prepared in 2001 on "The Socio-Economic Impact of Restructuring the Banana Industry" indicates a worsening of the poverty situation as a result of severe shocks to the economy since 1995. To rectify data lacunae regarding poverty and consumption expenditures, the government expects to conclude a new household survey and poverty assessment by end-2007.

The process of developing a poverty reduction strategy began in September 2001. The government assigned the responsibility for the development of a Poverty Reduction Framework to the National Economic and Social Development Council (NESDC), which comprises representatives from government ministries, the ECCB and other financial institutions, private sector, and civil society groups. A Poverty Reduction Task Force was established by the NESDC to develop the Poverty Reduction Strategy. The final revision of the Interim Poverty Reduction Strategy Paper (I-PRSP) was completed in June 2003, and is the only PRSP in the ECCU region developed by a country that does not have a Fund-supported arrangement. The NESDC is currently developing a National Development Plan (NDP) of which of the Poverty Reduction Strategy would be a component. The government plans to review and then revise the I-PRSP by end-2006.

The strategy for poverty reduction adopted by the government follows a multi-faceted approach, which includes: (i) a job creation program (including the Youth Empowerment Service to address youth unemployment); (ii) a low-income housing project; (iii) an enhanced safety net for the poor through public assistance; (iv) the promotion of a micro-enterprise sector; (v) increased subsidies to banana farmers; and (vi) large new infrastructure projects in roads, airports and power plants.

In order to promote civil society participation in national policy formulation, the NESDC has developed a "Social Contract" (which has a "Fiscal Covenant") and a Social Investment Fund. The contract aims at fixing the general framework for cooperation between government, private sector, and civil society in both policy formulation and monitoring. The fund, which is an independent quasi-government entity, is financed by European Union grants (EC\$14 million over a three-year period), and will (beginning in 2007) fund social projects sponsored by local communities.

The main component of the country's existing social safety net is the public assistance program administered by the Ministry of Social Development. This program currently assists some 5,000 persons with a monthly cash stipend of EC $\$ 125$ for those over 65 years of age, and EC $\$ 100$ for those less than 65 years.

The World Bank's 2005 Public Expenditure Review recommends the consolidation of existing public assistance programs and more transparent targeting. The government currently implements approximately 20 social assistance programs, through at least seven different line ministries and statutory agencies. However, social programs targeted to the poor are largely overlapping and administratively cumbersome, and are consequently not well poised to respond to chronic poverty. Government ministries are presently examining ways to reduce overlap. 


\section{E. Other Issues}

37. Despite ongoing efforts to enhance statistical databases in St. Vincent and the Grenadines, weaknesses remain in terms of coverage, timeliness and dissemination of statistical data. While in areas central to surveillance-notably central government accounts, indicators of the financial sector and external sector accounts - the data are adequate for surveillance purposes, information on the rest of the public sector and nonbank financial intermediaries is limited. The mission also encouraged the authorities to continue to strengthen the statistical office, in particular by continuing to avail themselves of technical assistance offered through CARTAC.

\section{StafF ApPraisal}

38. The economy of St. Vincent and the Grenadines' showed encouraging signs of strength in 2006. Activity is being driven by expansion in construction and tourism-related services, and by a recovery in weather-affected agricultural production. Prospects for a further growth pickup in 2007 appear bright, underpinned by improving external competitiveness, continued expansion in tourism and rising domestic investment.

39. However, the country's fiscal imbalances remain worrisome. Under current policies, debt servicing in 2006 will absorb the equivalent of about 25 percent of current revenues, and public debt will expand to over 100 percent of GDP by the end of the decade. In this light, a front-loaded fiscal adjustment is needed to place the debt ratio on a more sustainable path, increase the fiscal room for maneuver to address poverty alleviation and social needs, and enable the economy to better cope with adverse shocks. Welcome initiatives have been taken to achieve some fiscal consolidation in 2006, but further difficult measures will be needed to sustain and deepen the adjustment over the medium term.

\section{Encouraging steps have already been taken to improve tax policy and} administration, including the planned adoption of the VAT and the recent reduction of fuel subsidies. While these improvements will support the needed fiscal adjustment, it is still important for the authorities to remove discretionary tax concessions, and reduce the overall level of statutory concessions, in order to maintain revenue buoyancy and promote a tax environment that is more conducive to new investment. In addition, a flexible fuel pricing mechanism is needed to avoid consumption taxes being contingent on world oil prices.

\section{Success in boosting revenues should not be used to delay the introduction of} stricter spending discipline. It is critical that the authorities prioritize and properly phase infrastructure-enhancing projects, and fund these with grant financing and highly concessional loans. In addition, the government's wage bill, which accounts for about half of all current expenditures, is among the highest in the ECCU. Staff recommends that growth in the number of civil servants be strictly limited and wage increases be prudently managed. 
42. Staff urges the authorities to seek grants and highly concessional financing for the proposed new international airport. In addition, staff strongly encourages the government to undertake an updated economic feasibility study for the airport, given the cost of this project and its potential impact on the country's debt position. The study would highlight the costs and benefits of various potential designs and financing options.

43. St. Vincent and the Grenadines is one of the most disaster-prone countries in the world. In recent years the authorities have made strong efforts to bolster national disaster mitigation and preparedness. Nonetheless, staff recommends that the authorities undertake greater efforts to transfer or reduce disaster risk, particularly through enhanced insurance of public buildings, better enforcement of building codes, and continued participation in arrangements for regional pooling of catastrophe risk insurance.

44. Staff welcomes efforts by the authorities to reduce vulnerabilities related to the state-owned National Commercial Bank (NCB) and strengthen financial sector supervision. In addition to a continuation of ongoing efforts to improve its balance sheet, staff recommends that the NCB's management structure be strengthened and its exposure to the public sector be reduced. Staff urges that NBFIs be more carefully monitored, given their importance to the domestic financial sector. The authorities' plans to consolidate regulation and supervision of NBFIs is also welcomed, as is ongoing efforts to enhance supervision of the offshore financial sector.

45. The erosion of trade preferences for bananas is placing considerable pressure on rural households in St. Vincent and the Grenadines. Staff supports the authorities' plans to use temporary measures to ease the transition away from banana production, through income transfers, retraining programs, noncontributory pensions, and limited subsidies on agricultural inputs (to encourage diversification into nonbanana agriculture). Staff also notes the disappointingly large discrepancy between the planned allocation and actual disbursement of donor funds designed to facilitate the transition of the economy away from banana production. Nonetheless, it is critical that the government effectively uses planned EU assistance to ease the transition of the economy away from agriculture, through the development of a reform program which could be supported by donors and the EU.

46. Even in the best of circumstances, the economic and fiscal situation of St. Vincent and the Grenadines remains vulnerable. The debt burden is expected to remain high for several years, rendering the country vulnerable to adverse economic shocks. Key downside risks include the potential fiscal and economic impact of additional capital expenditures, the occurrence of natural disasters, and more rapid erosion of trade preferences for banana exports. The authorities will need to carefully manage these risks, and respond rapidly to any changes in the country's economic environment.

47. It is recommended that the next Article IV consultation take place on the standard 12-month cycle. 
Figure 1. St. Vincent and the Grenadines: Macroeconomic Developments, 1990-2005 (In percent of GDP, unless otherwise denoted)

Exogenous shocks have contributed to volatile growth...

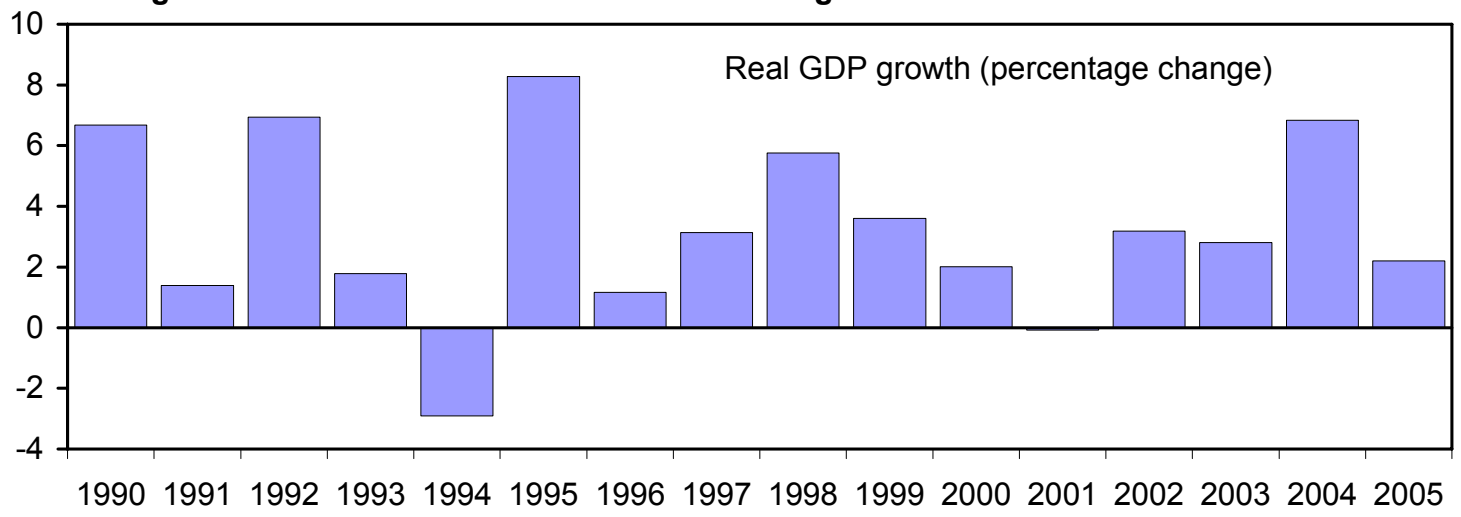

...banana exports have declined dramatically, while tourism has become the main growth sector...

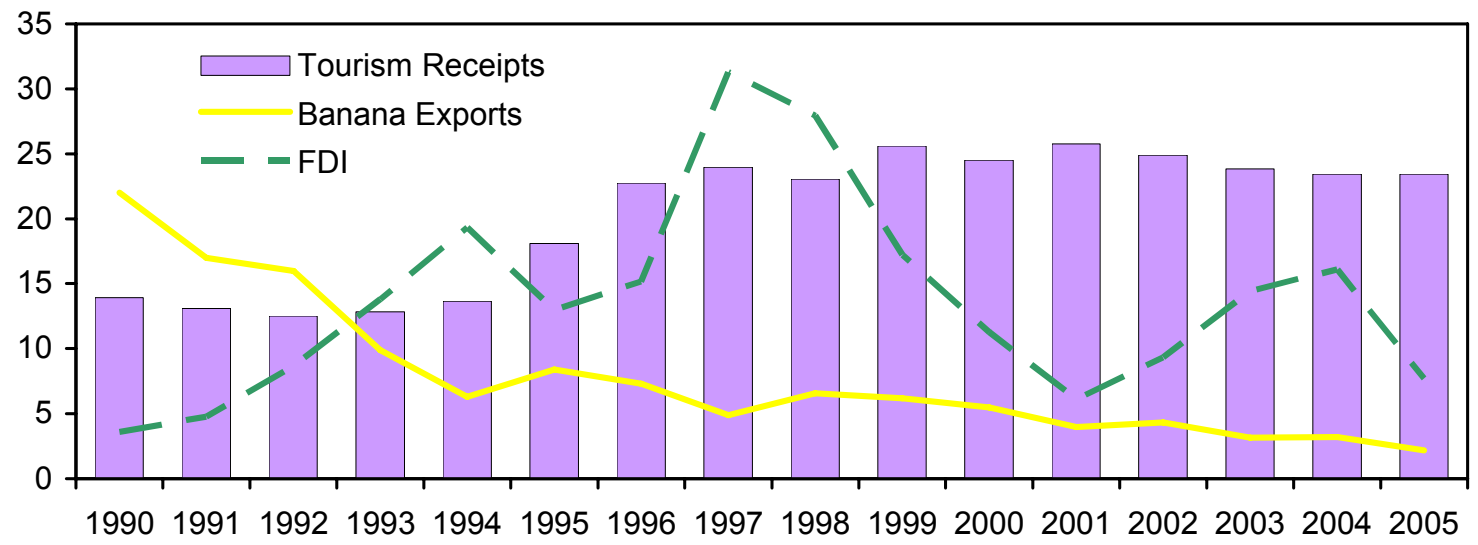

...and increasing interest payments and capital expenditure have compounded fiscal deficits.

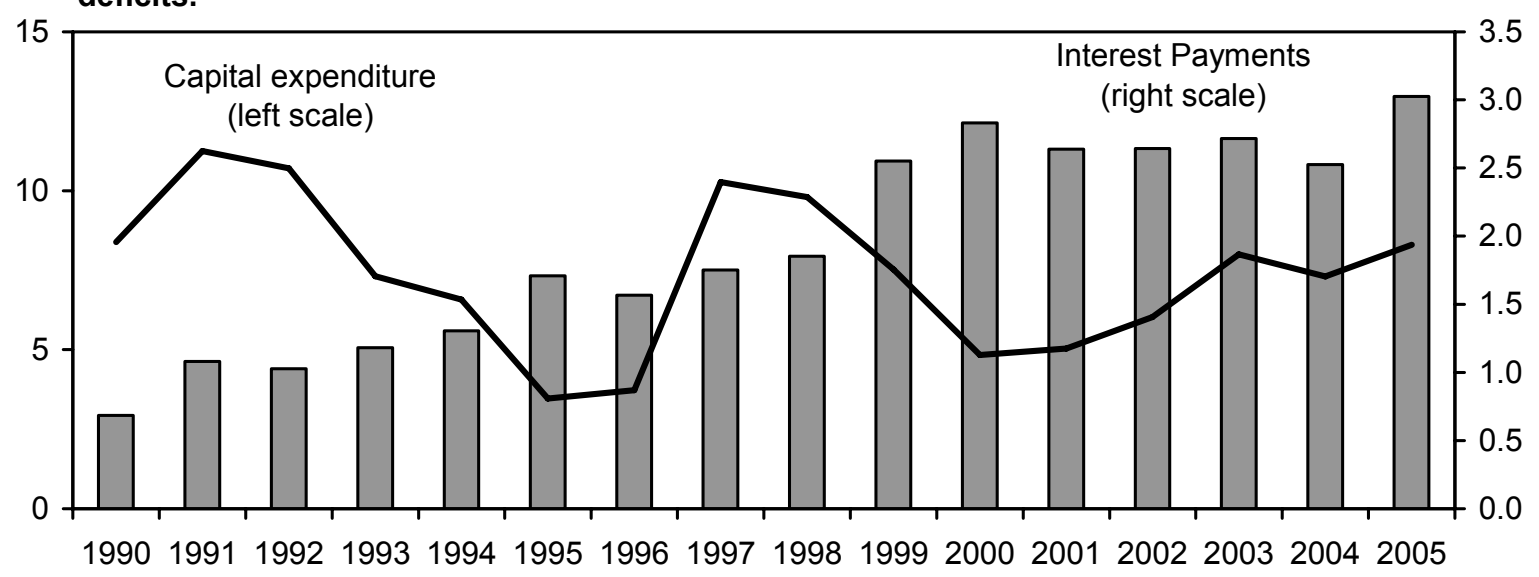

Sources: St. Vincent and the Grenadines authorities; and Fund staff estimates. 
Figure 2. St. Vincent and the Grenadines: Fiscal Developments, 1990-2005

(In percent of GDP, unless otherwise denoted)

There has been an increase in expenditures since 1997 and a sustained decline in revenues since 2002 ...

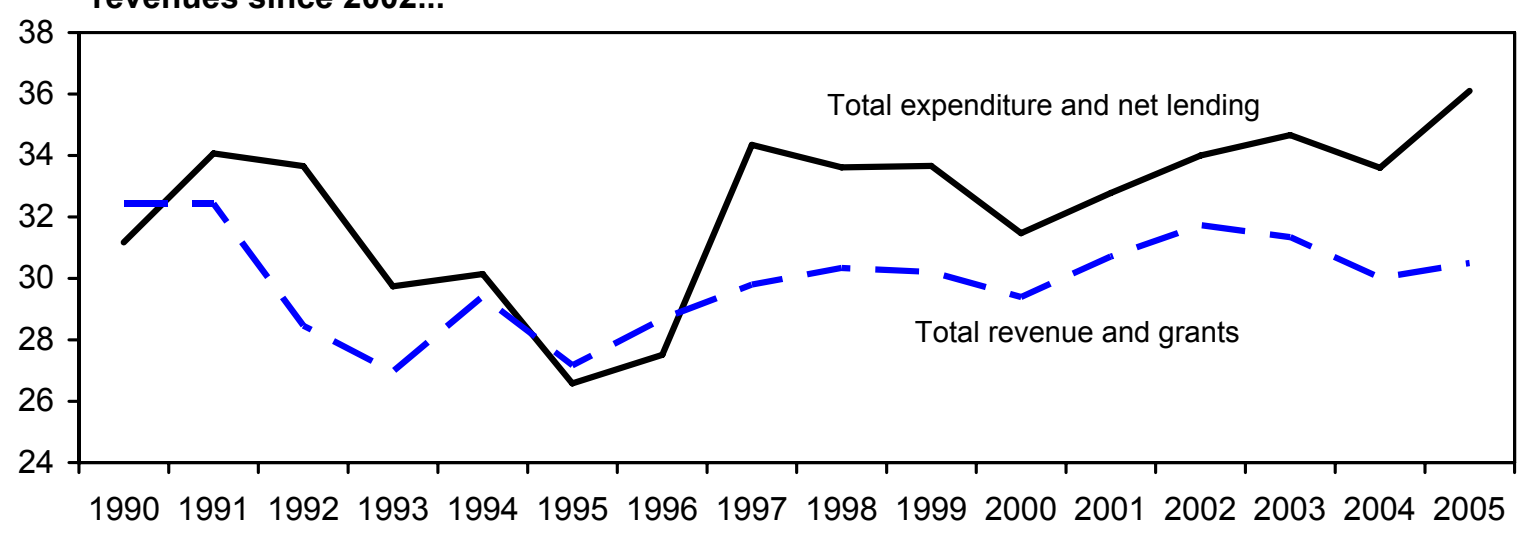

...with persistent and growing fiscal deficits, and the public assumption of a private external loan in 1999 ...

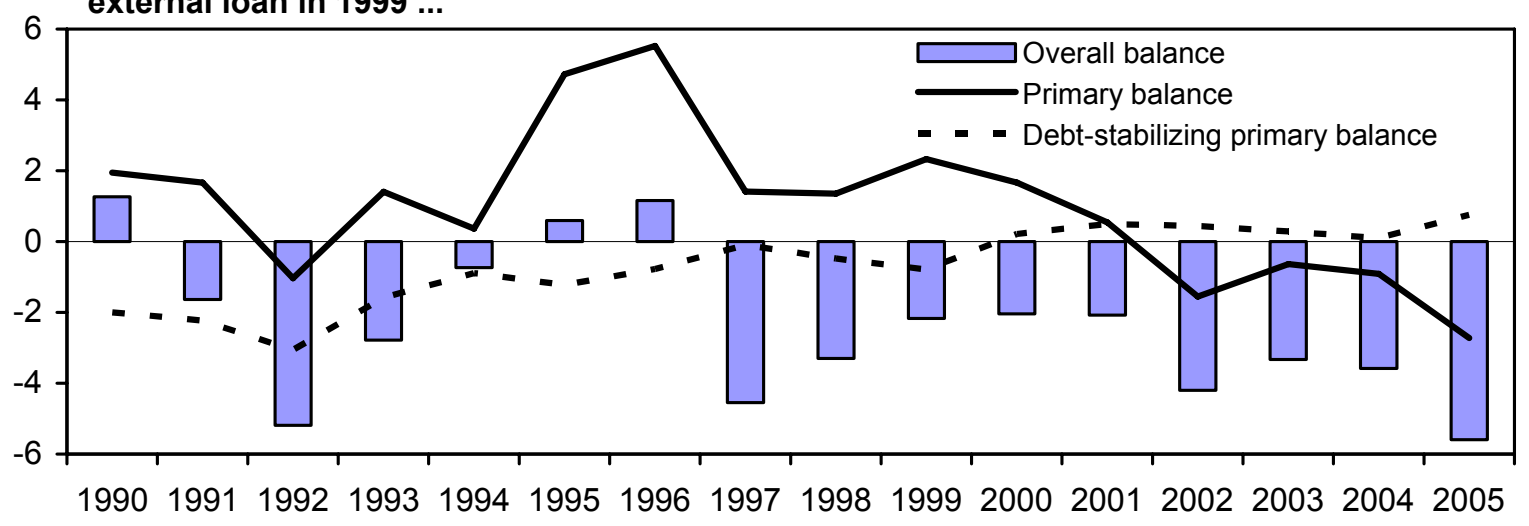

...leading to a rise in both the public stock of debt and the cost of debt servicing.

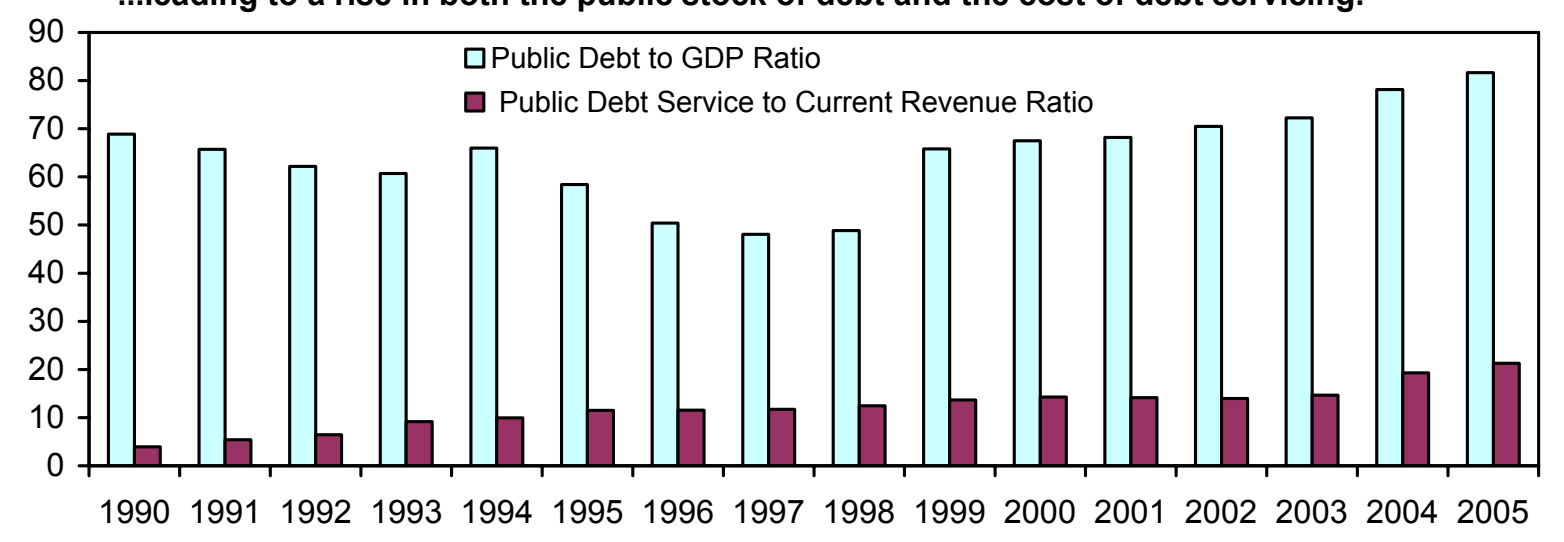

Sources: St. Vincent and the Grenadines authorities; and Fund staff estimates. 
Figure 3. St. Vincent and Grenadines: External Competitiveness, 1990-2006

While the CPI-based real effective exchange rate has depreciated sharply since $2002 \ldots$

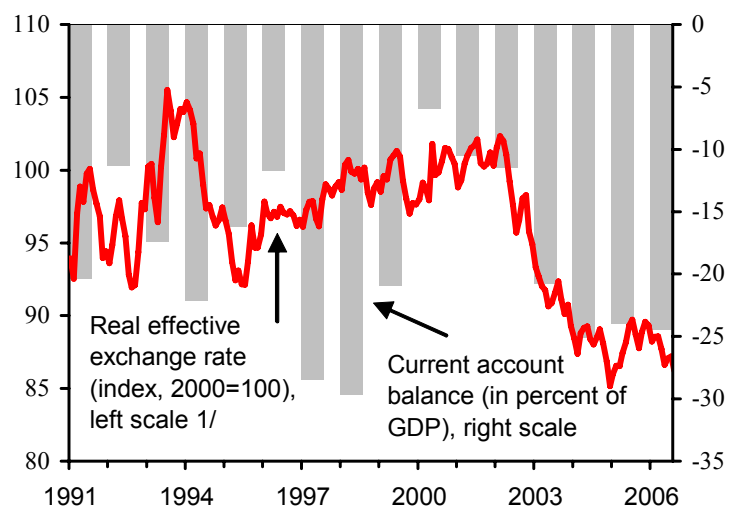

Overall exports have weakened, after growing rapidly during the early 1990 s...

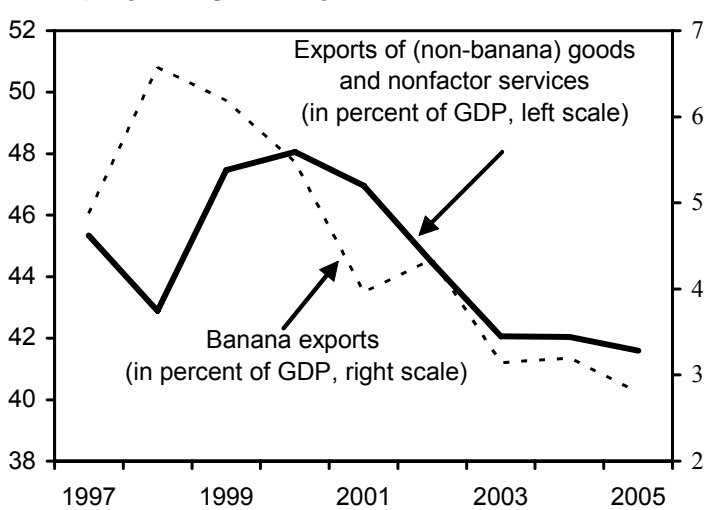

In the tourism sector, the competitor- and customerbased measures of the REER have depreciated...

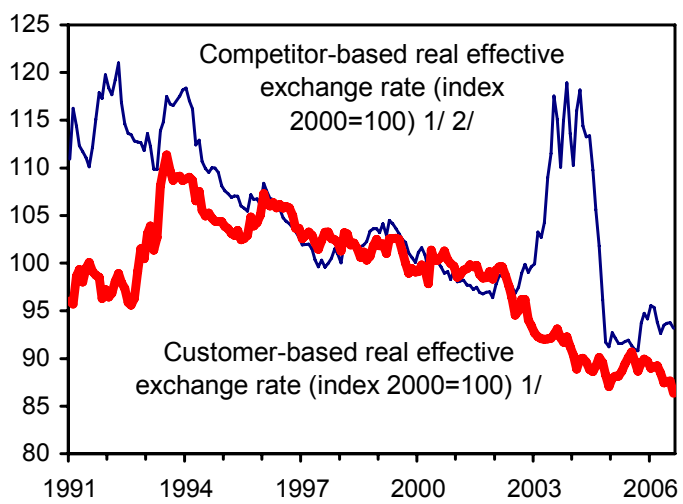

...private and public sector real wages and numbers of civil servants have grown.

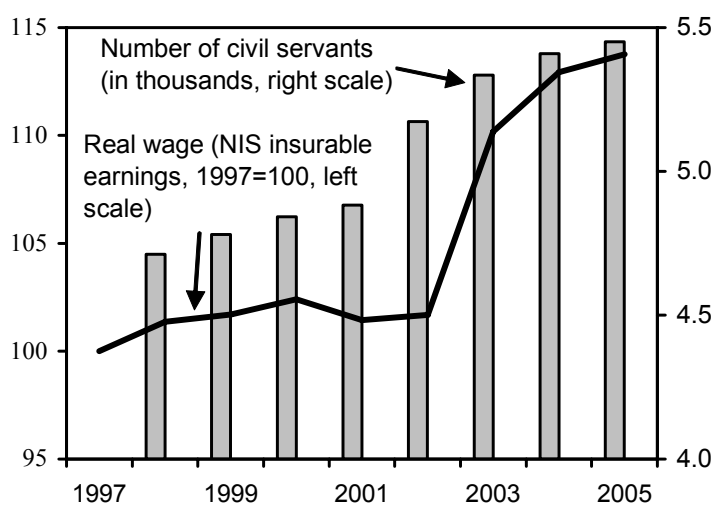

...while overseas development assistance flows have continued their steady decline since the early 1990 s.

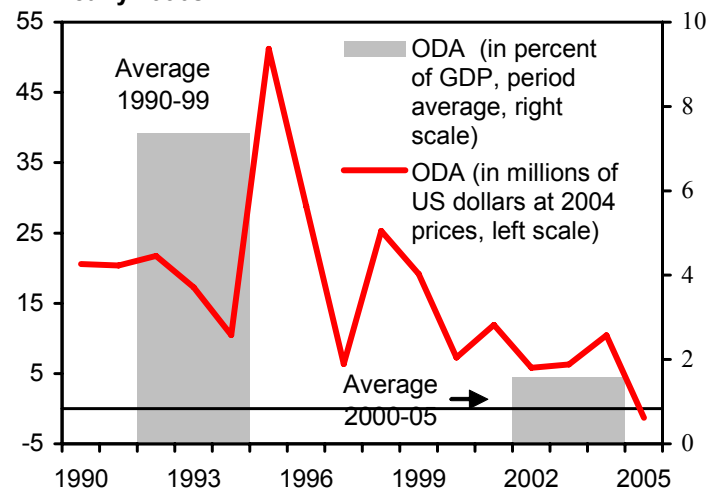

...while St. Vincent's share of stay-over arrivals in both the ECCU and the Caribbean has increased steadily since 1996.

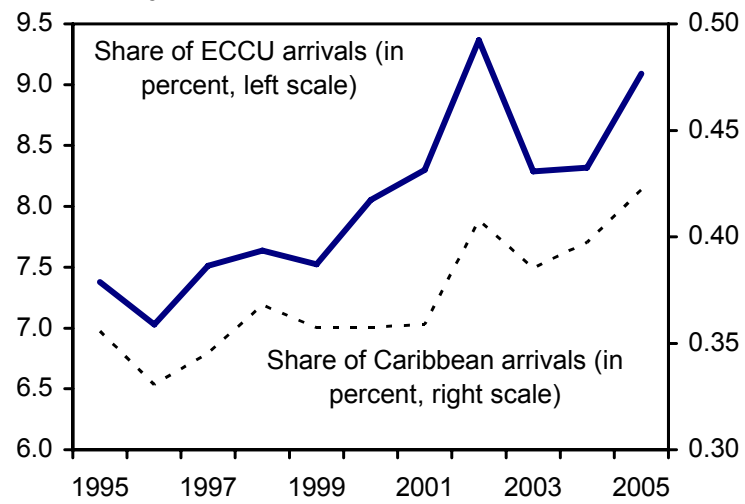

Sources: ECCB, Caribbean Tourism Organization, St. Vincent and the Grenadines authorities, and Fund staff calculations.

1/ An increase (decrease) indicates an appreciation (depreciation).

2/ The sharp movements in the competitor-based real exchange rate in 2002-04 were largely driven by the Dominican Republic's peso. 
Figure 4. St. Vincent and the Grenadines: Banking System Developments, 2000-06 1/

Since 2003, both lending and deposit rates have fallen, but spreads have remained broadly unchanged.

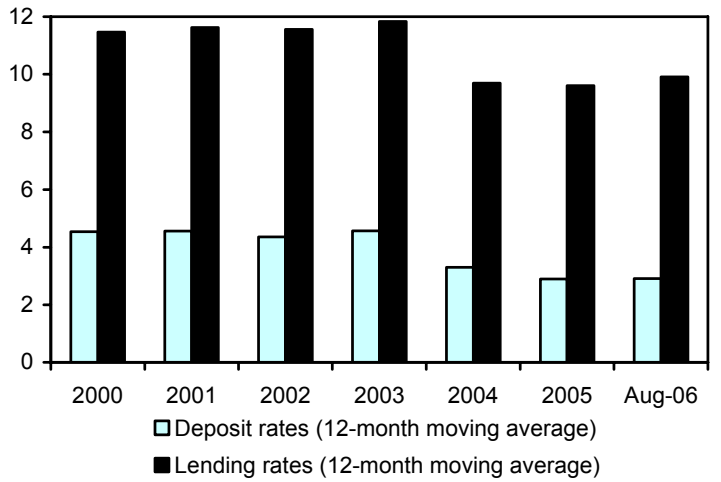

Household loans dominate the lending portfolio (both for foreign and local banks).

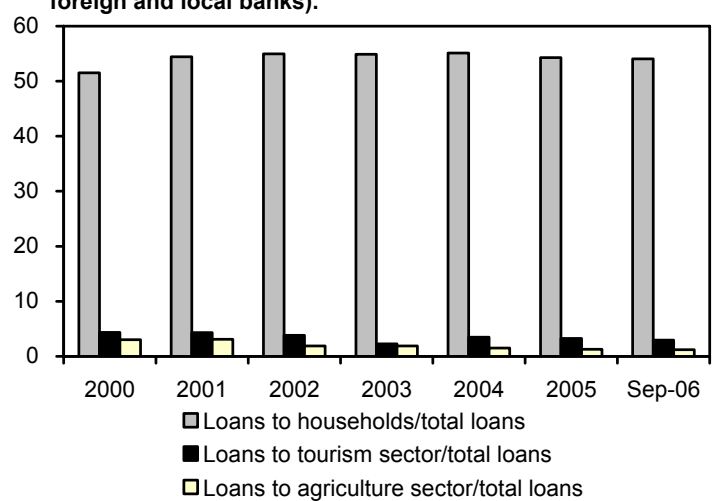

Government exposure and government deposits remain high for local banks, rendering the banking system vulnerable to impairment of government obligations.

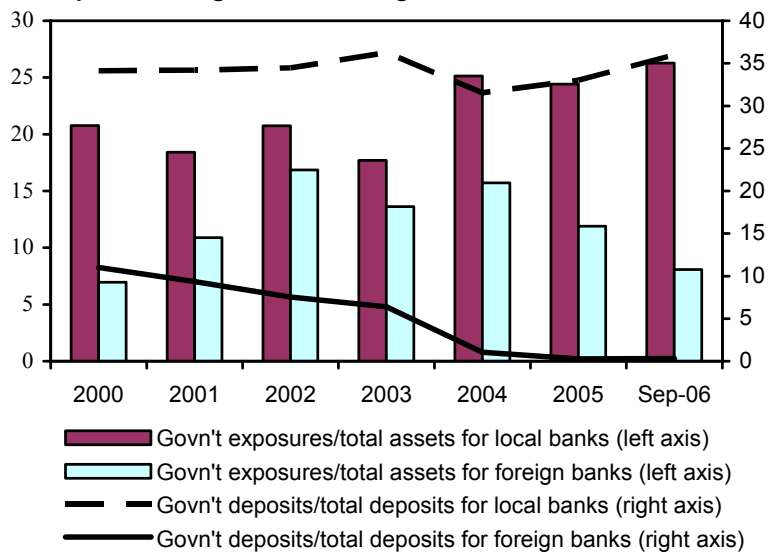

Foreign banks have been reducing excess liquidity and have become more profitable than local banks since 2003.

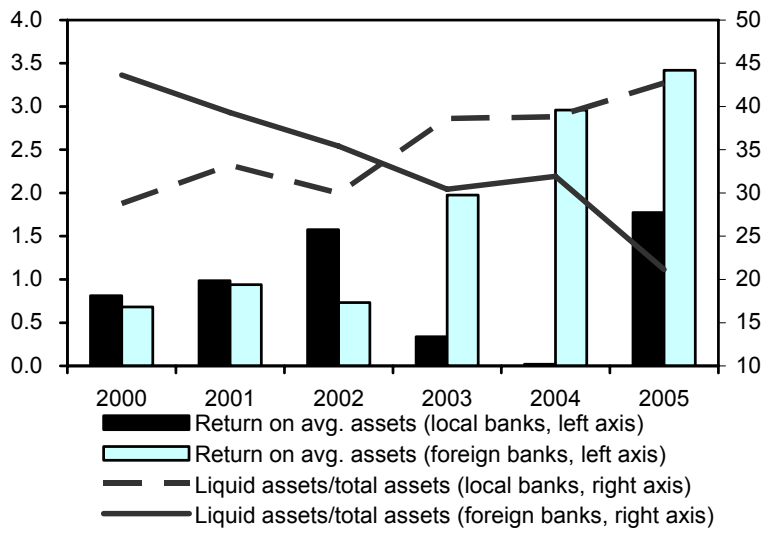

Nonperforming loans in local banks have decreased considerably since 2003, while provisioning has risen.

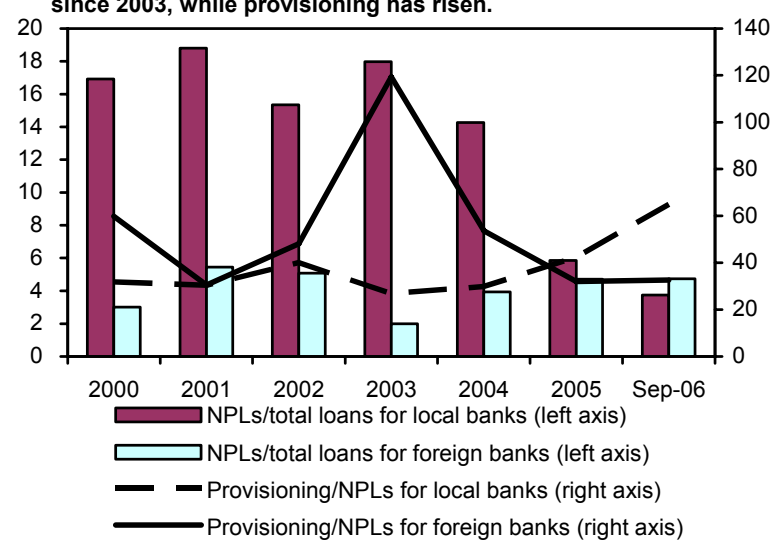

Capital adequacy ratios in local banks have steadily increased since 2003 to near the ECCU average.

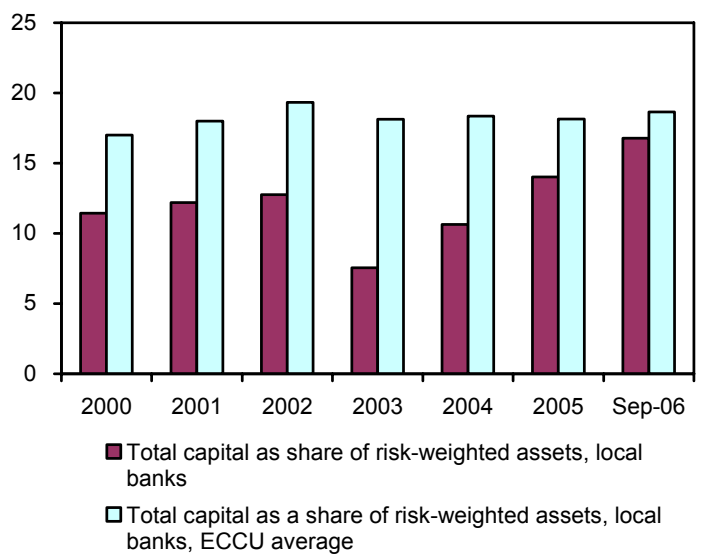

Sources: ECCB; and St. Vincent and the Grenadines authorities.

$1 /$ Prudential indicators are based on commercial banks' own reporting, with infrequent on-site verification by the ECCB. 
Figure 5. St. Vincent and the Grenadines: Governance and Business Indicators, 2005-06

\begin{tabular}{|c|c|c|c|c|c|c|}
\hline & $\begin{array}{l}\text { Antigua } \\
\& \text { Barb. }\end{array}$ & Dominica & Grenada & $\begin{array}{l}\text { St. Kitts } \\
\& \text { Nevis }\end{array}$ & St. Lucia & $\begin{array}{l}\text { St. } \\
\text { Vincent } \\
\text { \& } \\
\text { Grens. }\end{array}$ \\
\hline Voice and accountability & 62 & 86 & 72 & 73 & 81 & 81 \\
\hline Political stability & 72 & 83 & 62 & 94 & 87 & 88 \\
\hline $\begin{array}{l}\text { Government } \\
\text { effectiveness }\end{array}$ & 68 & 71 & 63 & 79 & 84 & 83 \\
\hline Regulatory quality & 68 & 71 & 63 & 84 & 84 & 84 \\
\hline Rule of law & 72 & 68 & 59 & 76 & 76 & 76 \\
\hline Control of corruption & 75 & 72 & 72 & 81 & 84 & 81 \\
\hline
\end{tabular}

\begin{tabular}{|c|c|c|c|c|c|c|}
\hline & Dominica & Grenada & St. Lucia & $\begin{array}{c}\text { St. } \\
\text { Vincent } \\
\text { \& Grens. }\end{array}$ & Guyana & Hait \\
\hline Economic management & 3.7 & 3.2 & 4.0 & 4.0 & 3.5 & 3.0 \\
\hline Structural policies & 4.2 & 4.0 & 4.2 & 4.2 & 3.5 & 3.2 \\
\hline $\begin{array}{l}\text { Policies for social } \\
\text { inclusion/equity }\end{array}$ & 3.7 & 3.9 & 3.8 & 3.8 & 3.3 & 2.6 \\
\hline $\begin{array}{l}\text { Public sector management } \\
\text { and institutions }\end{array}$ & 3.6 & 3.7 & 3.9 & 3.7 & 3.1 & 2.3 \\
\hline $\begin{array}{l}\text { Overall IDA resource } \\
\text { allocation index (IRAI) 2/ }\end{array}$ & 3.8 & 3.7 & 4.0 & 3.9 & 3.4 & 2.8 \\
\hline
\end{tabular}
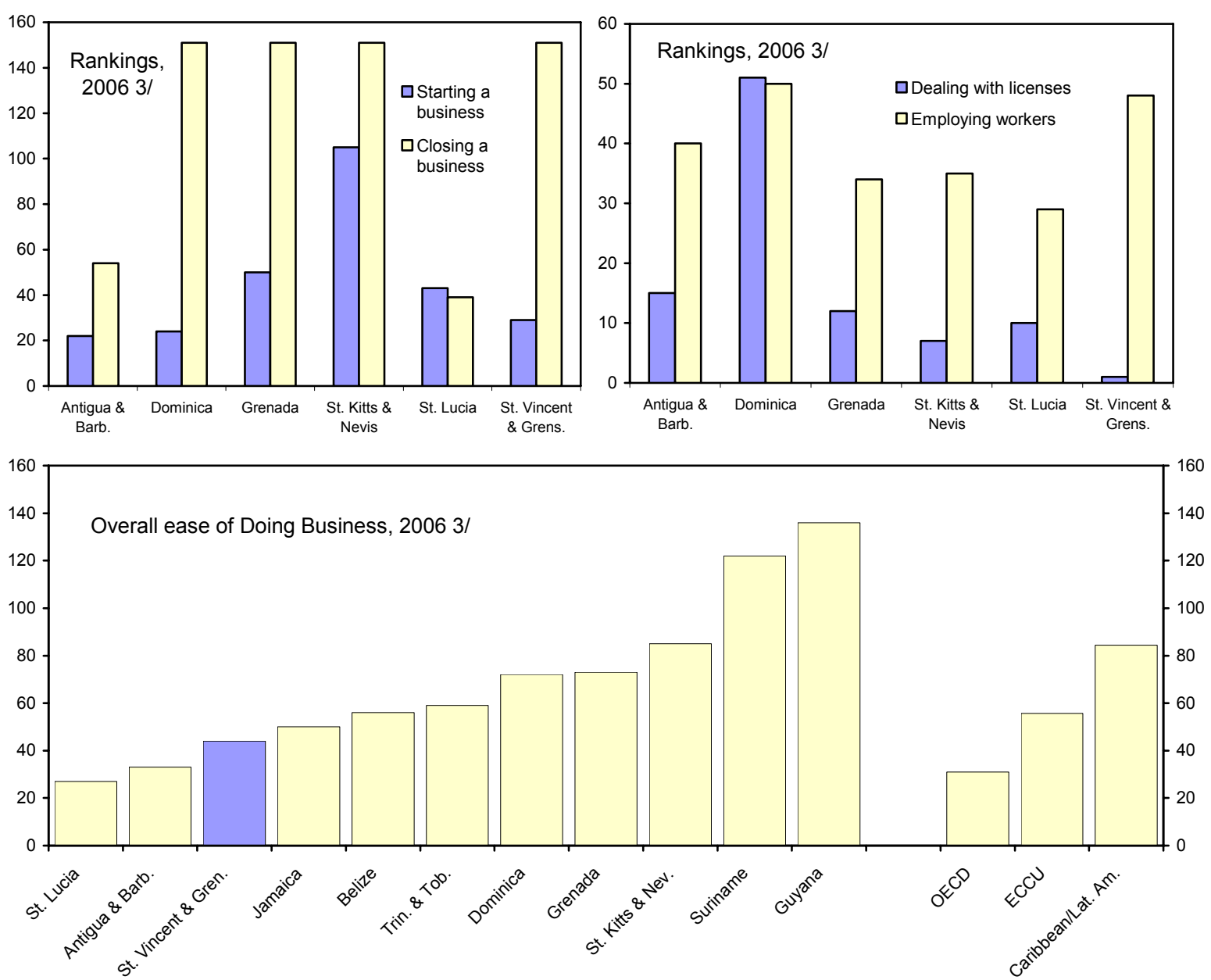

Sources: World Bank, "Governance Matters V: Governance Indicators for 1996-2005"; World Bank, International Development Association (IDA); and "Doing Business," World Bank.

1/ Ratings scale: 1 = lowest, 6 = highest.

$2 /$ Overall rating is calculated as the mean of the score of the four categories.

3/ "Doing Business" indicators: rank out of 175 economies, where 1 signifies most conducive and 175 least conducive. 
Figure 6. St. Vincent and the Grenadines: Public Debt Sustainability: Bound Tests 1/ (Public debt in percent of GDP)
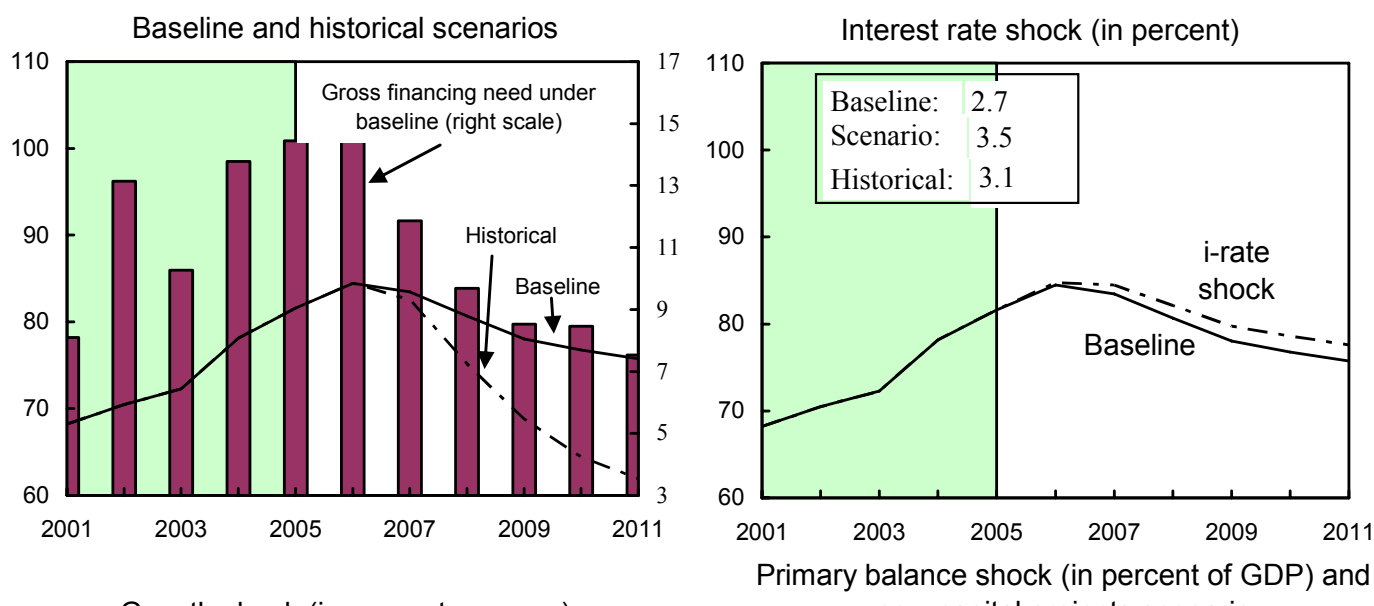

Growth shock (in percent per year)
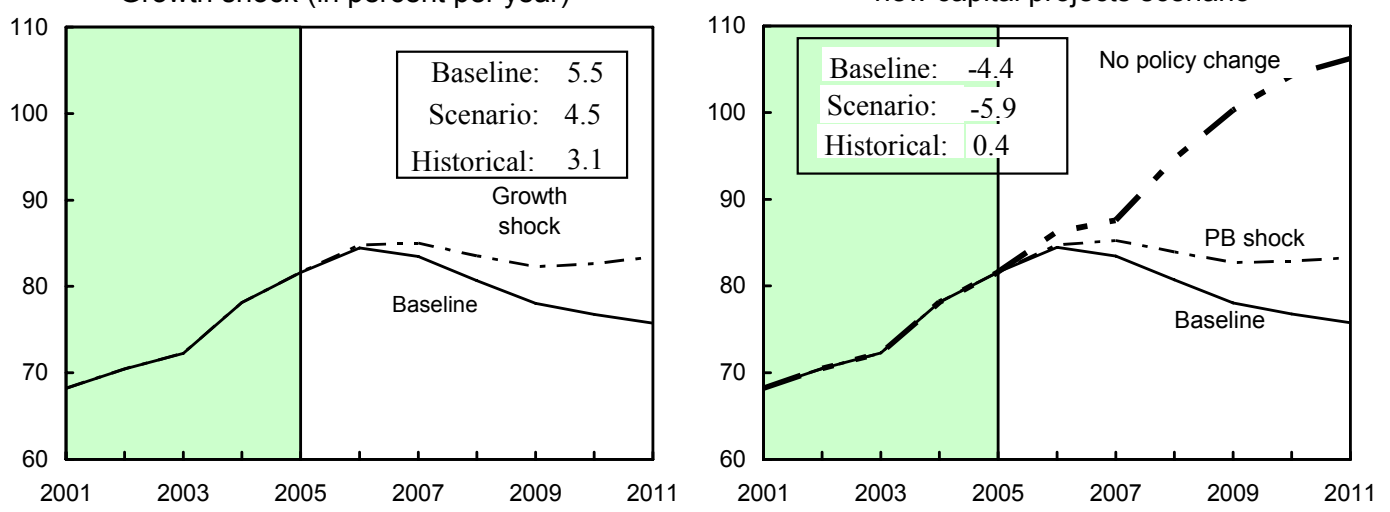

Combined shock 2/
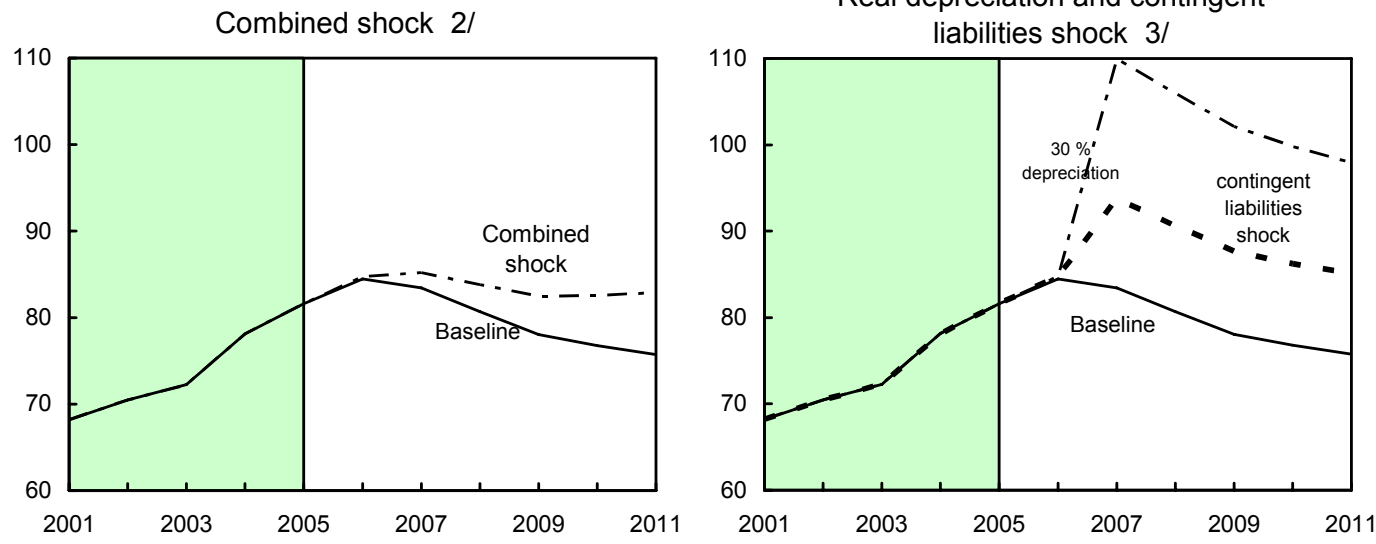

Sources: International Monetary Fund, Country desk data, and staff estimates.

1/ Shaded areas represent actual data. Individual shocks are permanent one-half standard deviation shocks. Figures in the boxes represent average projections for the respective variables in the baseline and scenario being presented. Ten-year historical average for the variable is also shown.

2/ Permanent 1/4 standard deviation shocks applied to real interest rate, growth rate, and primary balance. 3/ One-time real depreciation of 30 percent and 10 percent of GDP shock to contingent liabilities occur in 2006, with real depreciation defined as nominal depreciation (measured by percentage fall in dollar value of local currency) minus domestic inflation (based on GDP deflator). 
Table 1. St. Vincent and the Grenadines: Selected Social and Economic Indicators, 2001-07

\begin{tabular}{|c|c|c|c|c|c|c|c|}
\hline \multicolumn{8}{|c|}{ Social and Demographic Indicators } \\
\hline Area (sq. km) & 389.0 & \multicolumn{5}{|c|}{ Adult illiteracy rate (percent, 2001) } & 11.0 \\
\hline Population & & \multicolumn{6}{|c|}{ Health and nutrition } \\
\hline Total (thousands, 2006) & 106.8 & \multicolumn{5}{|c|}{ Calorie intake (per capita a day, 2004) } & 2,660 \\
\hline Rate of growth (percent per year, 2001) & 0.01 & \multicolumn{5}{|c|}{ Population per physician (thousand, 1997) } & 1.1 \\
\hline Density (per sq. km., 2006) & 274.6 & \multicolumn{5}{|c|}{ AIDS incidence rate (per $100,000,2004$ ) } & 99 \\
\hline Population characteristics (2004) & & \multicolumn{5}{|c|}{ Gross domestic product (2006) } & \\
\hline Life expectancy at birth (years) & 71.3 & \multicolumn{5}{|c|}{ (millions of US dollars) } & 466 \\
\hline Infant mortality (per thousand live births) & 18.0 & \multicolumn{5}{|c|}{ (millions of EC dollars) } & 1,258 \\
\hline \multirow[t]{2}{*}{ Under 5 mortality rate (per thousand) } & 22.0 & \multicolumn{5}{|c|}{ (US\$ per capita) } & 4,364 \\
\hline & 2001 & 2002 & 2003 & 2004 & $\begin{array}{r}\text { Est. } \\
2005 \\
\end{array}$ & $\begin{array}{l}\text { Proj. } \\
2006 \\
\end{array}$ & $\begin{array}{l}\text { Proj. } \\
2007 \\
\end{array}$ \\
\hline \multicolumn{8}{|c|}{ (Annual percentage change, unless otherwise specified) } \\
\hline \multicolumn{8}{|l|}{ Output and prices } \\
\hline Real GDP (factor cost) & -0.1 & 3.2 & 2.8 & 6.8 & 2.2 & 4.1 & 5.5 \\
\hline Nominal GDP (market prices) & 3.1 & 5.8 & 4.6 & 6.7 & 5.5 & 8.3 & 8.9 \\
\hline Consumer prices, end of period & -0.6 & 0.4 & 2.7 & 1.7 & 3.9 & 4.5 & 3.5 \\
\hline Consumer prices, period average & 0.8 & 0.8 & 0.2 & 3.0 & 3.7 & 3.2 & 3.9 \\
\hline Real effective exchange rate $(-=$ depreciation $)$ & -0.1 & -5.4 & -5.9 & -4.6 & 4.9 & .. & $\ldots$ \\
\hline External terms of trade $(-=$ deterioration $)$ & 2.9 & 2.6 & -4.9 & 0.0 & -4.3 & 0.6 & -2.1 \\
\hline \multicolumn{8}{|l|}{ Banking system } \\
\hline Net foreign assets $1 /$ & -4.1 & 2.9 & 5.7 & 15.7 & -4.6 & 1.4 & 1.9 \\
\hline $\begin{array}{l}\text { Net domestic assets } 1 / \\
\text { Of which }\end{array}$ & 7.2 & 5.4 & -3.9 & -2.0 & 11.0 & 6.9 & 6.9 \\
\hline \multirow[t]{2}{*}{ Credit to private sector $1 /$} & 2.1 & 4.3 & 0.6 & 0.8 & 4.3 & 1.7 & 2.9 \\
\hline & erwise spec & ecified) & & & & & \\
\hline Central government finances & & & & & & & \\
\hline Total revenue and grants & 30.7 & 31.7 & 31.3 & 30.0 & 30.5 & 31.1 & 31.7 \\
\hline Total expenditure and net lending & 32.8 & 34.0 & 34.7 & 33.6 & 36.1 & 35.4 & 34.3 \\
\hline Current expenditure & 27.7 & 28.0 & 26.7 & 26.3 & 27.8 & 27.7 & 26.7 \\
\hline Of which & & & & & & & \\
\hline Wages and salaries & 14.2 & 14.5 & 13.5 & 13.3 & 13.7 & 13.3 & 12.8 \\
\hline Interest & 2.6 & 2.6 & 2.7 & 2.5 & 3.0 & 3.9 & 3.4 \\
\hline Capital expenditure & 5.0 & 6.4 & 7.9 & 7.2 & 8.3 & 7.6 & 7.6 \\
\hline Overall balance (cash basis) 2/ & -2.1 & -4.2 & -3.3 & -3.6 & -5.6 & -4.2 & -2.6 \\
\hline Of which & & & & & & & \\
\hline Current balance (savings) & 1.0 & 2.6 & 4.1 & 2.9 & 1.2 & 1.9 & 3.6 \\
\hline Primary balance (after grants) & 0.5 & -1.6 & -0.6 & -1.1 & -2.6 & -0.4 & 0.8 \\
\hline Debt service in percent of current revenues & 14.1 & 14.0 & 14.7 & 19.3 & 21.3 & 24.9 & 23.9 \\
\hline Central government debt $3 /$ & 65.5 & 68.3 & 67.8 & 70.4 & 72.1 & 70.8 & 67.6 \\
\hline Public sector overall balance 4 / & -0.6 & -5.8 & -3.0 & -6.4 & -7.3 & -9.1 & -5.9 \\
\hline Public sector primary balance 4 / & 2.3 & -3.1 & -0.3 & -3.4 & -3.6 & -4.5 & -1.3 \\
\hline Public sector investment $4 /$ & 8.7 & 10.0 & 10.0 & 13.1 & 13.0 & 17.1 & 17.3 \\
\hline External sector & & & & & & & \\
\hline External current account & -10.5 & -11.5 & -20.8 & -25.1 & -24.0 & -24.5 & -24.9 \\
\hline Of which & & & & & & & \\
\hline Exports of goods and services & 50.9 & 48.8 & 45.2 & 45.2 & 44.4 & 45.3 & 44.8 \\
\hline Imports of goods and services & 60.2 & 58.8 & 63.1 & 66.7 & 64.7 & 65.3 & 65.8 \\
\hline Stayover arrivals (percentage change) & -3.0 & 9.8 & 1.2 & 10.4 & 9.5 & 5.0 & 7.0 \\
\hline Public sector external debt (end of period) & 49.1 & 46.5 & 50.9 & 54.1 & 54.7 & 53.3 & 50.7 \\
\hline External public debt service & & & & & & & \\
\hline In percent of exports of goods and services & 6.7 & 6.5 & 7.3 & 10.0 & 11.5 & 13.0 & 12.5 \\
\hline In percent of central government revenue before grants & 11.8 & 10.3 & 10.7 & 15.4 & 17.6 & 19.9 & 18.4 \\
\hline Memorandum items: & & & & & & & \\
\hline Average interest rate on the domestic public debt (in percent per annum) & 6.7 & 6.8 & 6.8 & 6.6 & 6.7 & 7.2 & 7.2 \\
\hline Average interest rate on the external public debt (in percent per annum) & 3.2 & 2.7 & 2.4 & 2.7 & 3.4 & 4.6 & 3.6 \\
\hline Gross public sector debt $3 / 4 /$ & 68.2 & 70.5 & 72.3 & 78.1 & 81.6 & 84.5 & 83.5 \\
\hline Nominal GDP at market prices (in millions of E.C. dollars) & 933 & 987 & 1,032 & 1,101 & 1,161 & 1,258 & 1,370 \\
\hline Nominal GDP at factor cost (in millions of E.C. dollars) & 777 & 817 & 852 & 931 & 972 & 1045 & 1145 \\
\hline Nominal GDP at market prices (in millions of U.S. dollars) & 345 & 365 & 382 & 408 & 430 & 466 & 507 \\
\hline Share of ECCU stayover visitors & 8.3 & 9.4 & 8.3 & 8.3 & 9.1 & $\ldots$ & $\ldots$ \\
\hline
\end{tabular}

Sources: Eastern Caribbean Central Bank, Ministry of Finance and Planning; Banana Growers' Association, and Fund staff estimates and projections.

1/ Annual changes relative to the stock of broad money at the beginning of the period.

2/ Includes the difference between the overall balance as measured from above the line and from below the line (i.e., financing), which may include float and unidentified discrepancies. 3/ Net of intra-public sector debt (mainly central government debt to the NIS).

4/ The consolidated public sector includes the central government, the National Insurance Services (NIS), Kingstown Board, and 10 nonfinancial public enterprises. 


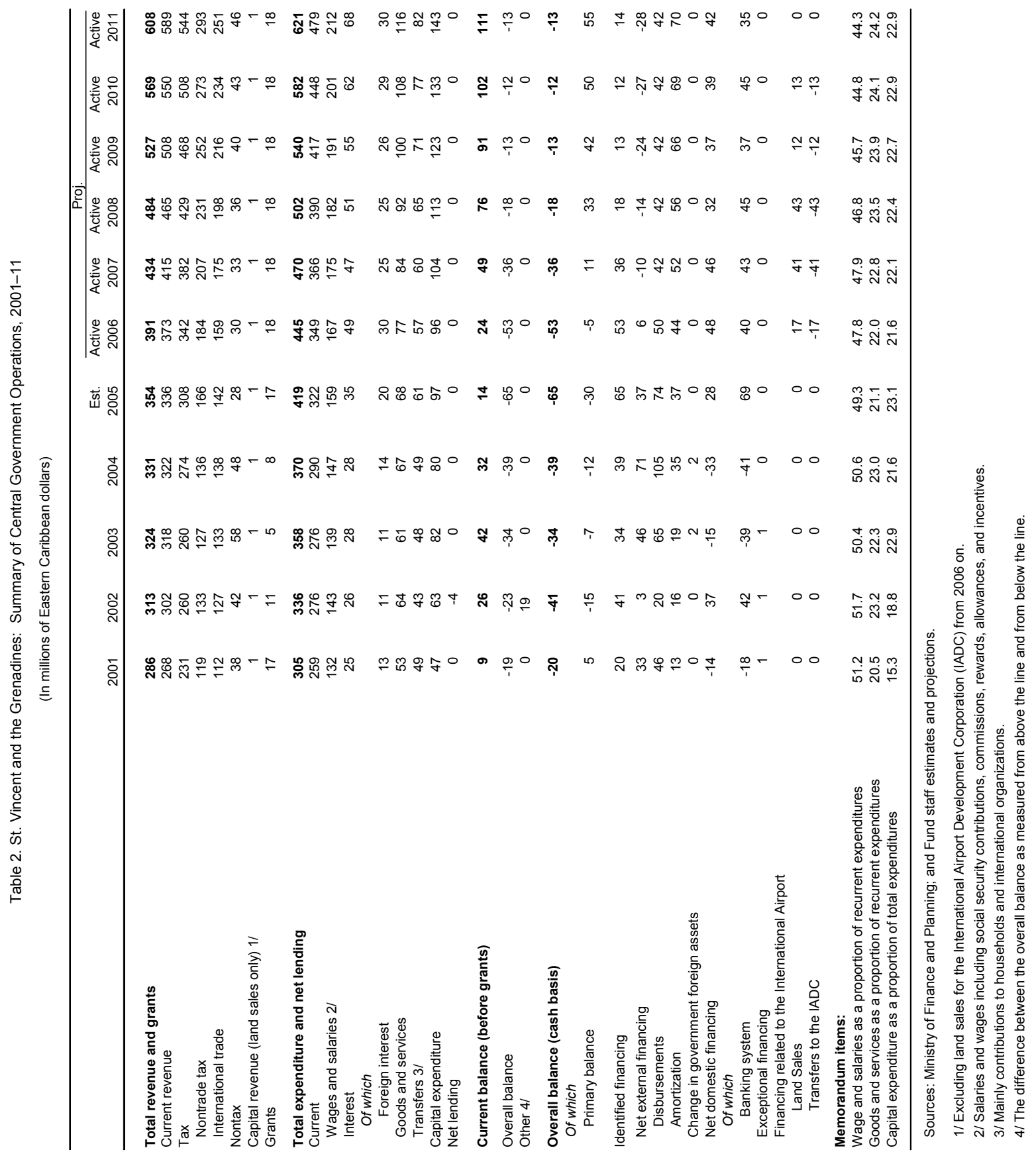


Table 3. St. Vincent and the Grenadines: Summary of Central Government Operations, 2001-11

(In percent of GDP, unless otherwise stated)

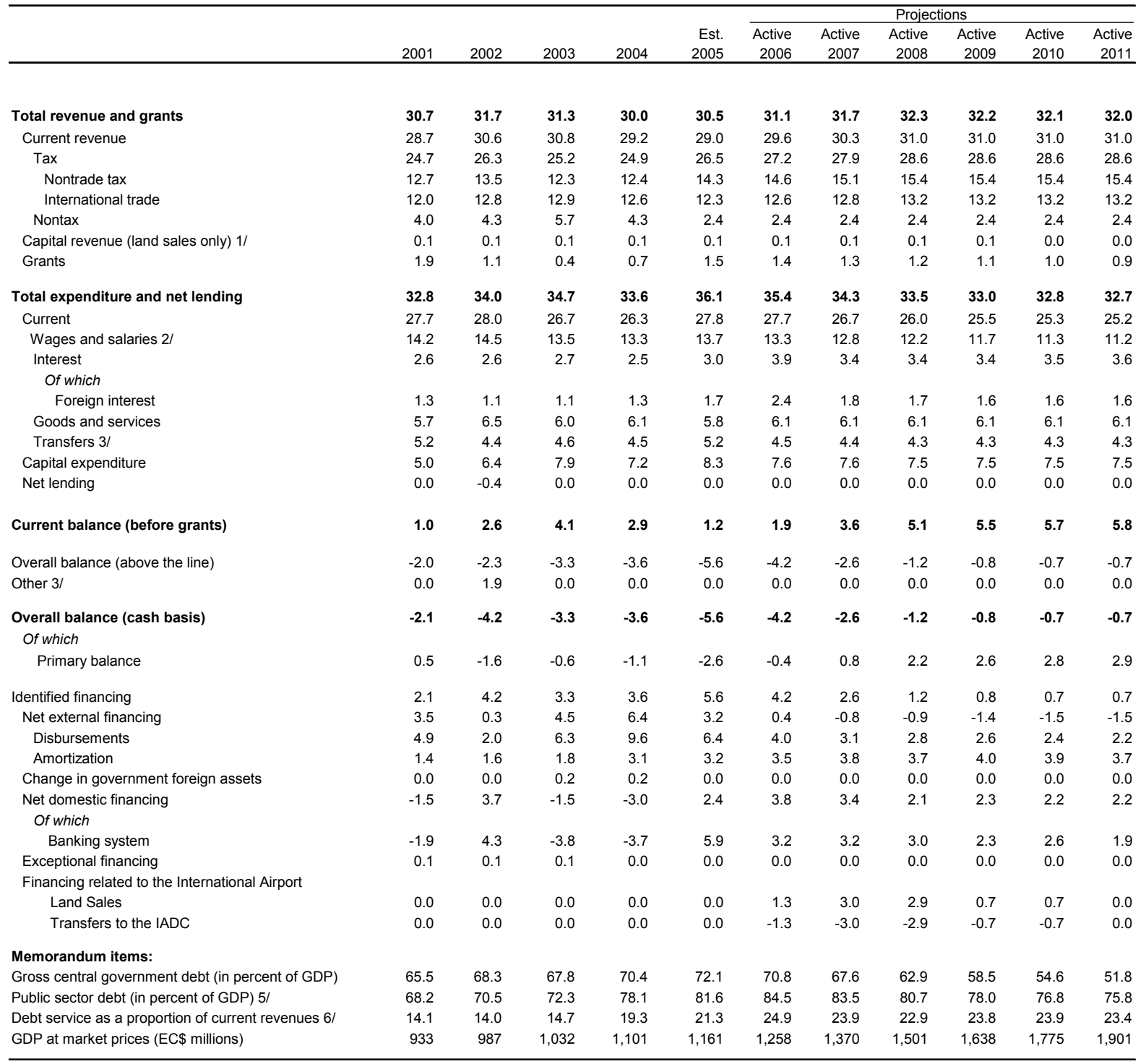

Sources: Ministry of Finance and Planning; and Fund staff estimates and projections.

1/ Excluding land sales for the International Airport Development Corporation (IADC) from 2006 on.

2/ Salaries and wages including social security contributions, commissions, rewards, allowances, and incentives.

$3 /$ Mainly contributions to households and international organizations.

4/ The difference between the overall balance as measured from above the line and from below the line.

$5 /$ Net of intra-public sector debt (mainly central government debt to the NIS).

6/ Debt service excludes domestic debt amortization. 
Table 4. St. Vincent and the Grenadines: Balance of Payments Summary, 2001-11 (Active Scenario)

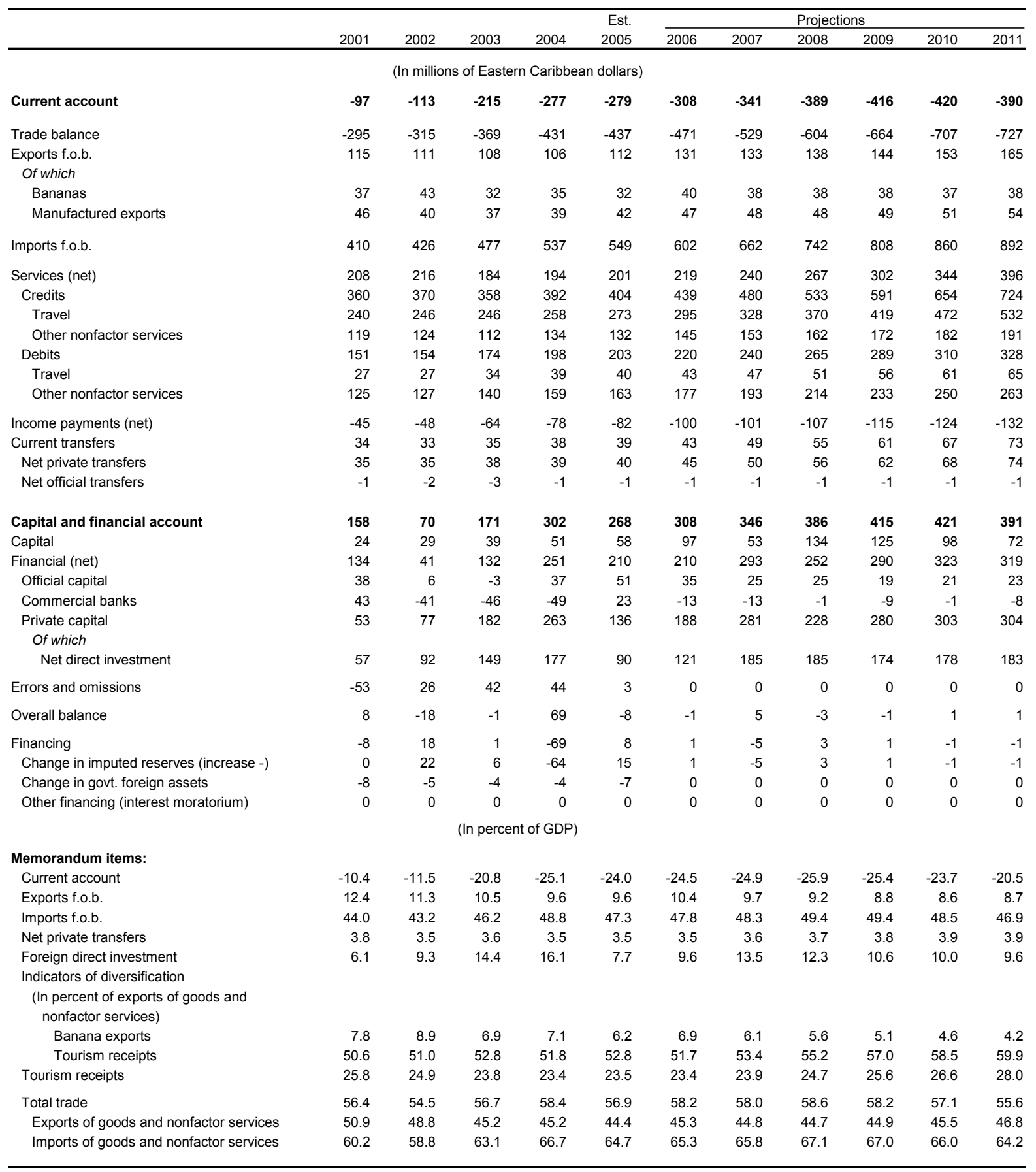

Sources: Ministry of Finance and Planning; ECCB; and Fund staff estimates and projections. 
Table 5. St. Vincent and the Grenadines: Monetary Survey, 2001-07

\begin{tabular}{|c|c|c|c|c|c|c|c|}
\hline & 2001 & 2002 & 2003 & 2004 & 2005 & $\begin{array}{l}\text { Proj. } \\
2006 \\
\end{array}$ & $\begin{array}{l}\text { Proj. } \\
2007 \\
\end{array}$ \\
\hline \multicolumn{8}{|c|}{ (In millions of Eastern Caribbean dollars) } \\
\hline Net foreign assets & 254 & 273 & 313 & 427 & 389 & 401 & 419 \\
\hline ECCB (imputed reserves) & 164 & 142 & 136 & 200 & 186 & 185 & 190 \\
\hline Commercial banks & 90 & 131 & 177 & 226 & 203 & 216 & 229 \\
\hline Net domestic assets & 401 & 436 & 409 & 395 & 485 & 546 & 611 \\
\hline Public sector credit (net) & -77 & -46 & -74 & -54 & 8 & 50 & 90 \\
\hline Central government & 44 & 86 & 47 & 6 & 74 & 114 & 158 \\
\hline ECCB & 8 & 12 & 24 & -31 & -13 & -12 & -11 \\
\hline Commercial banks & 36 & 74 & 23 & 37 & 87 & 126 & 168 \\
\hline Net credit to rest of public sector & -121 & -132 & -121 & -60 & -67 & -64 & -68 \\
\hline National Insurance Services & -139 & -141 & -137 & -100 & -82 & -85 & -89 \\
\hline Other & 18 & 9 & 16 & 40 & 15 & 21 & 21 \\
\hline Credit to private sector & 605 & 633 & 637 & 643 & 678 & 693 & 721 \\
\hline Net credit to nonbank financial institutions & -60 & -54 & -56 & -23 & -32 & -28 & -30 \\
\hline Other items (net) & -68 & -98 & -99 & -171 & -169 & -170 & -169 \\
\hline Broad money & 655 & 709 & 722 & 821 & 874 & 947 & 1031 \\
\hline Money & 219 & 239 & 254 & 287 & 328 & 355 & 386 \\
\hline Currency in circulation & 52 & 54 & 57 & 64 & 74 & 81 & 88 \\
\hline Demand deposits & 168 & 185 & 197 & 223 & 253 & 274 & 299 \\
\hline Quasi-money & 436 & 470 & 469 & 534 & 546 & 592 & 644 \\
\hline Time deposits & 143 & 156 & 137 & 124 & 101 & 110 & 120 \\
\hline Savings deposits & 285 & 304 & 321 & 384 & 430 & 466 & 507 \\
\hline Foreign currency deposits & 8 & 10 & 10 & 26 & 15 & 16 & 17 \\
\hline \multicolumn{8}{|c|}{ (Annual percentage change) } \\
\hline Net foreign assets & -9.4 & 7.4 & 14.9 & 36.2 & -8.9 & 3.1 & 4.6 \\
\hline Net domestic assets & 12.8 & 8.9 & -6.3 & -3.5 & 22.9 & 12.5 & 12.0 \\
\hline Credit to private sector & 2.3 & 4.6 & 0.6 & 0.9 & 5.5 & 2.2 & 4.0 \\
\hline Broad money & 3.0 & 8.3 & 1.9 & 13.7 & 6.4 & 8.3 & 8.9 \\
\hline Money & 3.3 & 9.1 & 6.1 & 13.1 & 14.2 & 8.3 & 8.9 \\
\hline Quasi-money 1/ & 2.9 & 7.9 & -0.3 & 14.0 & 2.2 & 8.3 & 8.9 \\
\hline \multicolumn{8}{|c|}{ (Percent contribution compared to M2 at the beginning of the year) } \\
\hline Net foreign assets & -4.1 & 2.9 & 5.7 & 15.7 & -4.6 & 1.4 & 1.9 \\
\hline Net domestic assets & 7.2 & 5.4 & -3.9 & -2.0 & 11.0 & 6.9 & 6.9 \\
\hline Public sector credit (net) & 0.3 & 4.8 & -4.0 & 2.7 & 7.6 & 4.9 & 4.2 \\
\hline Of which & & & & & & & \\
\hline Central government & -2.9 & 6.4 & -5.5 & -5.7 & 8.3 & 4.6 & 4.6 \\
\hline Credit to private sector & 2.1 & 4.3 & 0.6 & 0.8 & 4.3 & 1.7 & 2.9 \\
\hline Net credit to nonbank financial institutions & -3.5 & 0.9 & -0.3 & 4.5 & -1.1 & 0.5 & -0.2 \\
\hline Other items (net) & 8.3 & -4.6 & -0.2 & -10.0 & 0.3 & -0.1 & 0.1 \\
\hline \multicolumn{8}{|l|}{ Memorandum items: } \\
\hline Income velocity of $\mathrm{M} 2$ & 1.4 & 1.4 & 1.4 & 1.3 & 1.3 & 1.4 & 1.5 \\
\hline Deposit interest (average rate per annum) & 4.6 & 4.4 & 4.6 & 3.3 & 2.9 & $\ldots$ & . \\
\hline Lending interest rate (average rate per annum) & 11.6 & 11.6 & 11.8 & 9.7 & 9.4 & $\ldots$ & \\
\hline Foreign currency deposits/GDP (in percent) & 0.8 & 1.0 & 1.0 & 2.4 & 1.3 & 1.2 & 1.2 \\
\hline Broad money/GDP (in percent) & 70.2 & 71.9 & 70.0 & 74.6 & 75.3 & 69.1 & 68.7 \\
\hline
\end{tabular}

Sources: ECCB; Ministry of Finance and Planning; and Fund staff estimates.

$1 /$ Including resident foreign currency deposits. 
Table 6. St. Vincent and the Grenadines: Medium-Term Projections, 2001-11

(In percent of GDP, unless otherwise specified)

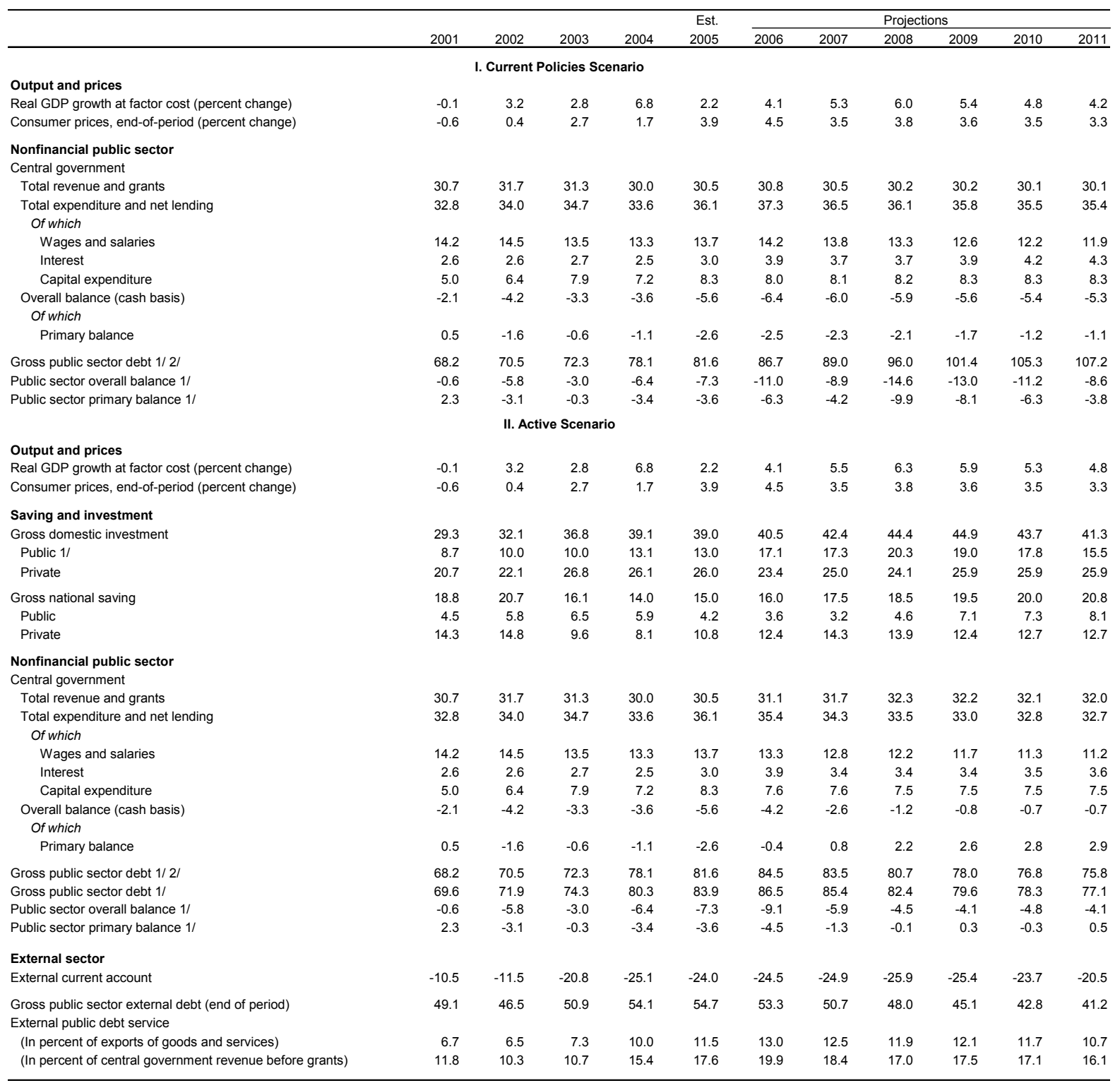

Source: Fund staff projections.

1/ The consolidated public sector includes the central government, the National Insurance Services (NIS), Kingstown Board, and ten nonfinancial public enterprises. 2/ Net of intra-public sector debt (mainly central government debt to the NIS). 
Table 7. St. Vincent and the Grenadines: Public Sector Debt, 2001-05 1/

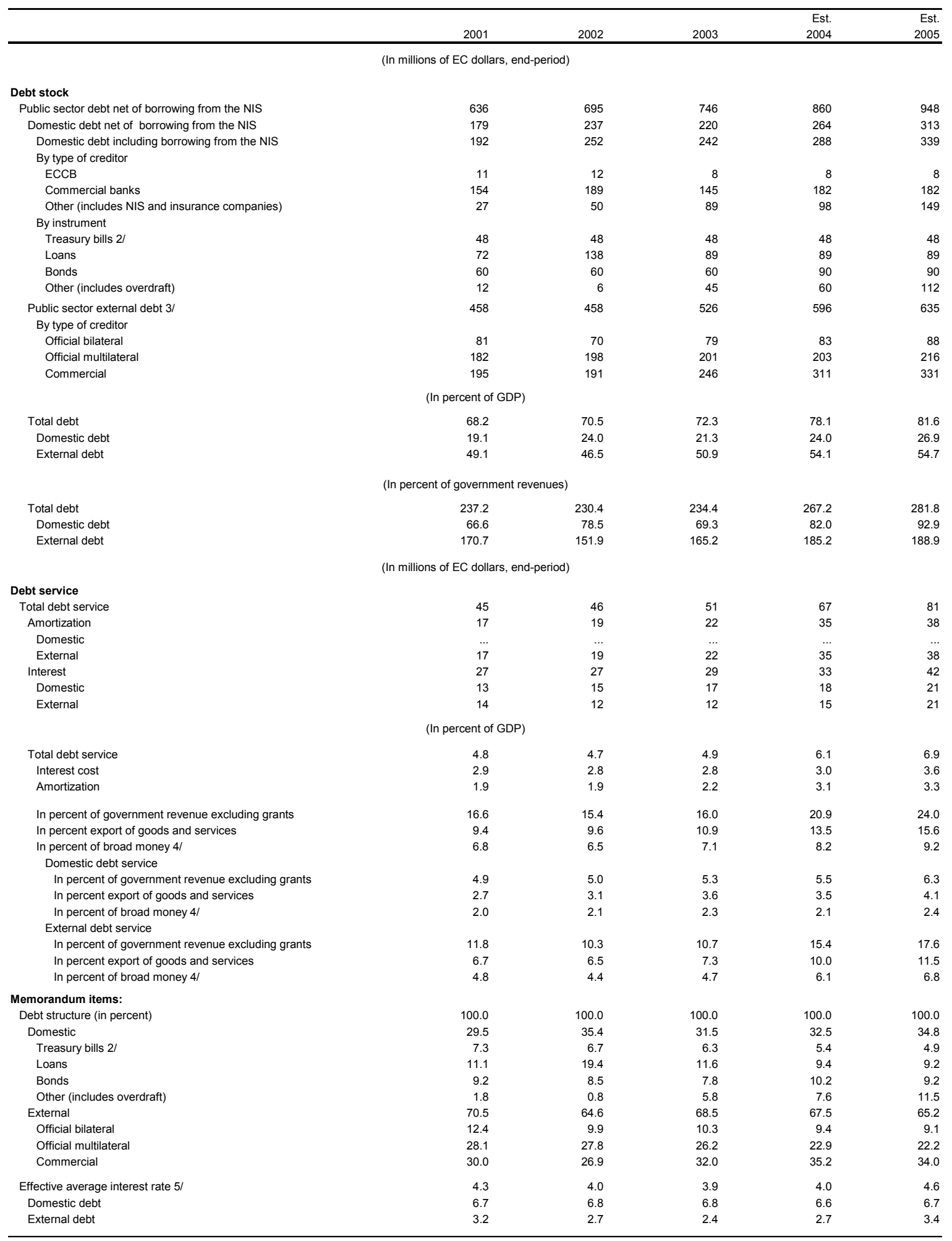

Sources: Ministry of Finance and Planning; and Fund staff estimates.

1/ Net of intra-public sector debt (mainly central government debt to the NIS). The consolidated public sector includes the government, the National Insurance Services (NIS), Kingstown Board, and 10 nonfinancial public enterprises.

2/ Treasury bills purchased by nonresidents on the RGSM since March 2003, are included.

$3 /$ Includes the assumption of private debt for Ottley Hall shipyard in 1999

4/ Including foreign currency deposits.

$5 /$ Interest payment as percent of the average debt stock at beginning and end period. 


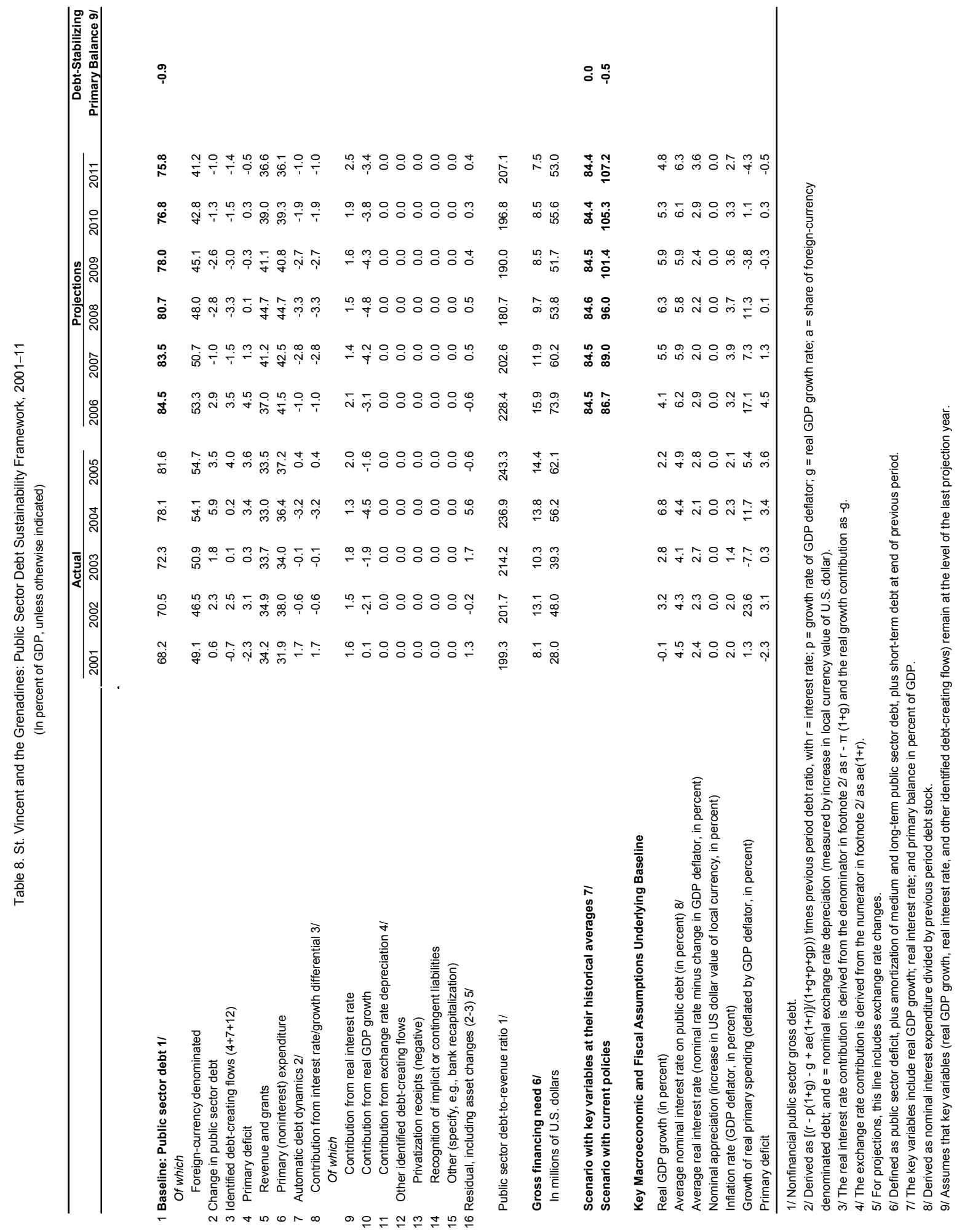




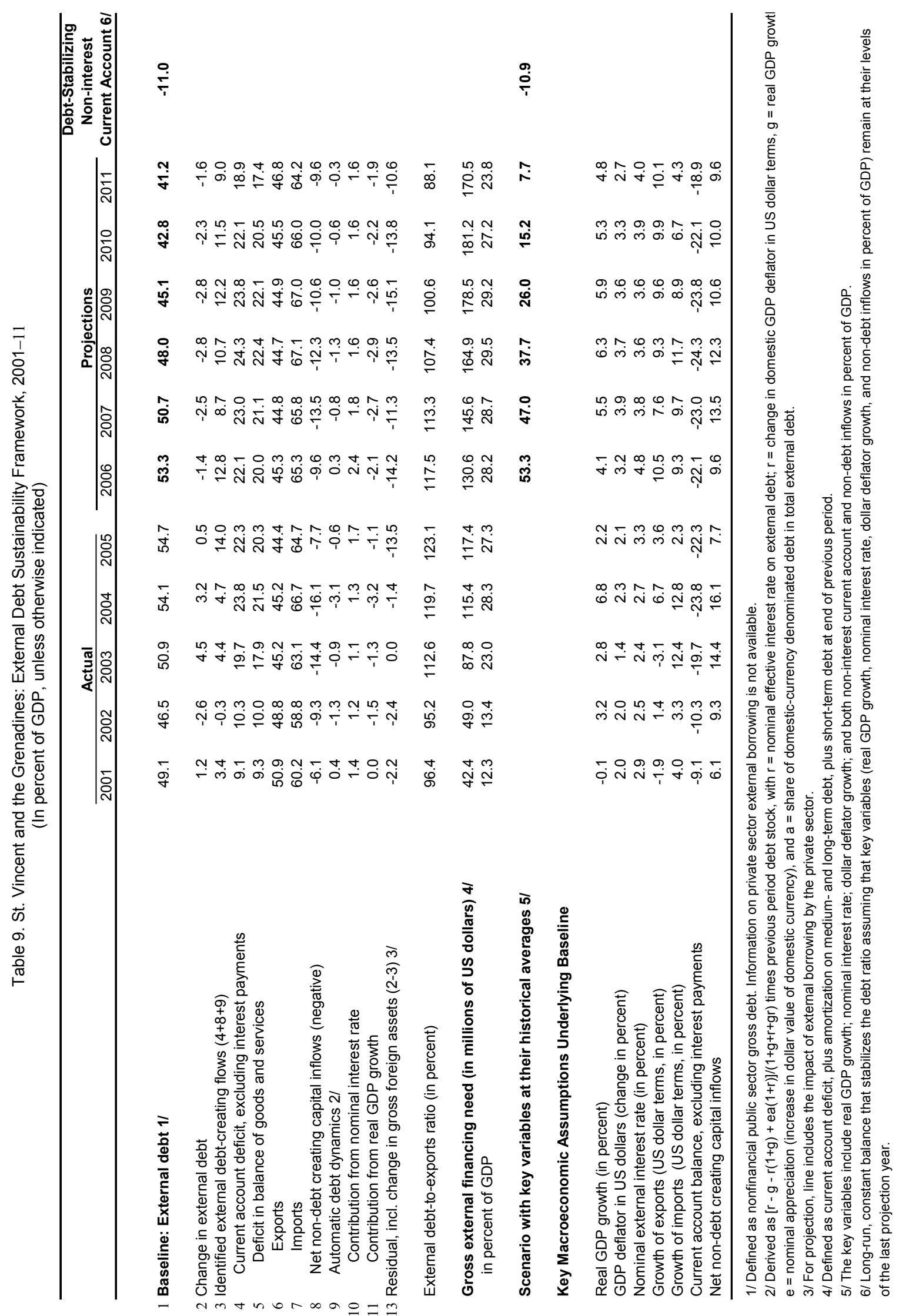


Table 10. St. Vincent and the Grenadines: Indicators of External and Financial Vulnerability, 2001-06 (Annual percentage changes, unless otherwise specified)

\begin{tabular}{|c|c|c|c|c|c|c|}
\hline & 2001 & 2002 & 2003 & 2004 & $\begin{array}{r}\text { Est. } \\
2005\end{array}$ & $\begin{array}{l}\text { Proj. } \\
2006\end{array}$ \\
\hline \multicolumn{7}{|l|}{ External indicators } \\
\hline Merchandise exports & -17.4 & -3.5 & -2.8 & -2.0 & 5.5 & 17.2 \\
\hline Merchandise imports & 5.3 & 3.8 & 12.1 & 12.5 & 2.2 & 9.6 \\
\hline Terms of trade deterioration (-) & 2.9 & 2.6 & -4.9 & 0.0 & -4.3 & 0.6 \\
\hline Tourism earnings & 8.3 & 2.3 & 0.2 & 4.8 & 5.6 & 8.1 \\
\hline Banana export earnings & -25.4 & 16.0 & -25.2 & 10.0 & -8.9 & 23.3 \\
\hline Current account balance (in percent of GDP) & -10.4 & -11.5 & -20.8 & -25.1 & -24.0 & -24.5 \\
\hline $\begin{array}{l}\text { Capital and financial account balance (in percent of GDP) 1/ } \\
\text { Of which }\end{array}$ & 11.2 & 9.7 & 20.7 & 31.4 & 23.3 & 24.4 \\
\hline Foreign direct investment (in percent of GDP) & 6.1 & 9.3 & 14.4 & 16.1 & 7.7 & 9.6 \\
\hline \multicolumn{7}{|l|}{ Gross international reserves of the ЕССВ } \\
\hline In millions of U.S. dollars & 446.0 & 504.8 & 540.0 & 632.4 & 600.8 & 652.9 \\
\hline In percent of broad money & 19.1 & 20.2 & 19.8 & 20.5 & 17.9 & 17.8 \\
\hline \multicolumn{7}{|l|}{ Gross imputed reserves } \\
\hline In millions of U.S. dollars & 60.8 & 52.5 & 50.4 & 74.2 & 68.8 & 68.5 \\
\hline In percent of short-term liablilities & 250.9 & 347.0 & 148.5 & 143.2 & 131.9 & ... \\
\hline Commercial banks' net foreign assets (in millions of U.S. dollars) & 33.3 & 48.6 & 65.6 & 83.9 & 75.2 & 80.0 \\
\hline External public debt (in percent of GDP) & 49.1 & 46.5 & 50.9 & 54.1 & 54.7 & 53.3 \\
\hline \multicolumn{7}{|l|}{ External debt service (in percent of exports of goods and } \\
\hline $\begin{array}{l}\text { nonfactor services) } \\
\text { Of which }\end{array}$ & 6.7 & 6.5 & 7.3 & 10.0 & 11.5 & 13.0 \\
\hline Interest & 3.0 & 2.6 & 2.5 & 3.1 & 4.1 & 5.3 \\
\hline Nominal exchange rate (E.C. dollars per U.S. dollar, end period) & 2.7 & 2.7 & 2.7 & 2.7 & 2.7 & 2.7 \\
\hline Real effective exchange rate depreciation (-), end period & -0.1 & -5.4 & -5.9 & -4.6 & 4.9 & $\ldots$ \\
\hline \multicolumn{7}{|l|}{ Financial indicators } \\
\hline Broad money & 3.0 & 8.3 & 1.9 & 13.7 & 6.4 & 8.3 \\
\hline Credit to the private sector & 2.3 & 4.6 & 0.6 & 0.9 & 5.5 & 2.2 \\
\hline \multicolumn{7}{|l|}{ Prudential indicators (in percent) $2 /$} \\
\hline Capital adequacy ratio (local banks) & 12.2 & 12.8 & 7.5 & 10.6 & 14.0 & $\ldots$ \\
\hline NPLs to total loans ratio & 13.0 & 11.3 & 11.1 & 9.6 & 5.3 & $\ldots$ \\
\hline \multicolumn{7}{|l|}{ Of which } \\
\hline Local banks & 18.8 & 15.3 & 18.0 & 14.3 & 5.9 & $\ldots$ \\
\hline Foreign banks & 5.4 & 5.1 & 2.0 & 3.9 & 4.7 & $\ldots$ \\
\hline Loan loss provision to NPLs ratio & 30.4 & 41.5 & 34.1 & 34.3 & 38.4 & $\ldots$ \\
\hline \multicolumn{7}{|l|}{ Of which } \\
\hline Local banks & 30.4 & 40.0 & 26.9 & 29.8 & 42.5 & $\ldots$ \\
\hline Foreign banks & 30.4 & 48.1 & 119.4 & 53.5 & 32.0 & $\ldots$ \\
\hline Gross government claims to total assets ratio & 15.2 & 19.2 & 16.1 & 20.3 & 19.8 & $\ldots$ \\
\hline Foreign currency deposits to total deposits ratio & 4.5 & 3.4 & 3.0 & 4.2 & 3.8 & $\ldots$ \\
\hline Net foreign currency exposure to capital (local banks) & 39.4 & 42.4 & 187.1 & 421.9 & 313.3 & $\ldots$ \\
\hline Contingent liabilities to capital (local banks) & 66.2 & 51.0 & 48.6 & 147.3 & 73.1 & $\ldots$ \\
\hline (Pre-tax) return on average assets & 1.0 & 1.2 & 1.0 & 1.2 & 2.4 & $\ldots$ \\
\hline Three-month treasury bill rate 3 / & 7.0 & 7.0 & 5.7 & 4.6 & 4.8 & $\ldots$ \\
\hline
\end{tabular}

Sources: Eastern Caribbean Central Bank; Ministry of Finance; and Fund staff estimates and projections.

$1 /$ Includes errors and omissions.

2/ Prudential indicators are based on commercial banks' own reporting, with infrequent on-site verification by the ECCB.

3/ As of December 28, 2005. 
Table 11. St. Vincent and the Grenadines: Millennium Development Goals Country Profile

1. Eradicate extreme poverty and hunger
Prevalence of child malnutrition (percent of children under 5)

2. Achieve universal primary education

Net primary enrollment ratio (percent of relevant age group)

Primary completion rate (percent of relevant age group)

Percentage of cohort reaching grade 5 (percent)

3. Promote gender equality

Ratio of girls to boys in primary and secondary education (percent)

Proportion of seats held by women in national parliament (percent)

\section{Reduce child mortality}

Under 5 mortality rate (per 1,000)

Infant mortality rate (per 1,000 live births)

Immunization, measles (percent of children under 12 months)

\section{Improve maternal health}

Maternal mortality ratio (modeled estimate, per 100,000 live births) Births attended by skilled health staff (percent of total)

\section{Combat HIVIAIDS, malaria and other diseases}

Prevalence of HIV, female (percent ages 15-24)

Contraceptive prevalence rate (percent of women ages 15-49)

Number of children orphaned by HIVIAIDS

Incidence of tuberculosis (per 100,000 people)

Tuberculosis cases detected under DOTS (percent)

7. Ensure environmental sustainability

Forest area (percent of total land area)

Nationally protected areas (percent of total land area)

$\mathrm{CO} 2$ emissions (metric tons per capita)

Access to an improved water source (percent of population)

Access to improved sanitation (percent of population)

8. Develop a Global Partnership for Development

Youth unemployment rate (percent of total labor force ages 15-24)

Fixed line and mobile telephones (per 1,000 people)

Personal computers (per 1,000 people)

Internet users (per 1,000 people)

General indicators

Population (thousands)

Gross national income (in millions of U.S. dollars)

GNI per capita (in U.S. dollars)

Total fertility rate (births per woman)

Life expectancy at birth (years)

Aid (percent of GNI)
2015 target $=$ halve $1990 \$ 1$ a day poverty and malnutrition rates

20

2015 target $=$ net enrollment to 100

$\begin{array}{lllll}. . & 93.0 & . . & . . & 9 \\ 73.5 & . & 94.0\end{array}$

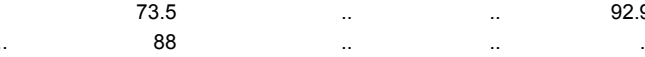

2005 target $=$ education ratio to 100

$\begin{array}{rrrrr}. . & 101.7 & . . & 101.6 & 95.6\end{array}$

2015 target $=$ reduce 1990 under 5 mortality by two-thirds

$\begin{array}{lllll}22 & 22 & 25 & 27 & 22 \\ 18 & 21 & 22 & 22 & 18 \\ 99 & 99 & 99 & 94 & 99\end{array}$

2015 target $=$ reduce 1990 maternal mortality by three-fourths

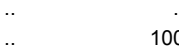

2015 target $=$ halt, and begin to reverse, AIDS, etc.

100

$\begin{array}{lrrrr}. . & . . & . & . . & . . \\ . . & . . & . . & . . & . . \\ . . & . . & . . & . . & . . \\ . . & 28 & 28.9 & 29.2 & 28.5 \\ . . & 19.1 & . . & . . & 33.0\end{array}$

$\begin{array}{llll}26 & \text {.. } & \text {.. } & 28\end{array}$

$\begin{array}{rrrrr}. . & 26 & . . & . . & 28 \\ . . & 21.0 & 21.3 & . .\end{array}$

$\begin{array}{rrrrr}. . & 21.0 & 21.3 & . . & . . \\ 1.2 & 1.5 & . . & . .\end{array}$

93.0

96.0.

2015 target $=$ various $2 /$

$\begin{array}{rrrrr}. . & . . & . . & . . & . . \\ 166.6 & 291.9 & 318.8 & 318.8 & 641.5 \\ . . & 113.0 & 119.7 & . . & 135.1 \\ . & & & . & 67.6\end{array}$

$\begin{array}{lllll}106.3 & 106.3 & 106.3 & . . & 106.3\end{array}$

$\begin{array}{lllll}247.5 & 321.8 & 330.2 & . . & 361.4 \\ 2,328 & 3,027 & 3,106 & 3,310 & 3,400\end{array}$

$\begin{array}{lllll}2.3 & 2.1 & 2.1 & 2.1 & 2.1\end{array}$

$\begin{array}{lrrr}72.2 & 72.9 & 72.9 & 72.9\end{array}$

18.7

\section{4}

Sources: World Development Indicators database, October 2006, and Fund staff estimates.

1 / Integrate the principles of sustainable development into country policies and programs and reverse the loss of environmental resources. Halve, by 2015 , the proportion of people without sustainable access to safe drinking water.

2/ Develop further an open, rule-based, predictable, nondiscriminatory trading and financial system. Address the Special Needs of the Least Developed and landlocked countries, and of small island developing states. Deal comprehensively with the debt problems of developing countries through national and international measures in order to make debt sustainable in the long term. In cooperation with developing countries, develop and implement strategies for decent and productive work for youth. In cooperation with pharmaceutical companies, provide access to affordable, essential drugs in development countries. In cooperation with the private sector, make available the benefits of new technologies, especially information and communications. 


\title{
Annex I. Medium-Term Outlook Under Alternative Fiscal Scenarios
}

\author{
The risk of current fiscal policies leading to an unsustainable level of public debt has \\ risen, given the increasing pressure for capital expenditure. In the absence of \\ containment of expenditures elsewhere, notably in wages and salaries, and a determined \\ increase in revenues, current debt dynamics are quite unfavorable.
}

For the analysis of the medium-term prospects for the economy of St. Vincent and the Grenadines, staff simulated two fiscal scenarios. A first (current policies) scenario was predicated upon the broad continuation of existing policies; the second (active) scenario was based on significant additional policy adjustment, and garnering of additional resources from external donors. Under the current policies scenario, the debt stock and debt servicing costs continue to rise rapidly; under the active scenario discussed in the text, the stock of debt declines gradually over the medium term.

Current policies scenario. The authorities continue current expansionary policies with very large overall imbalances that are financed commercially, and also through some grants from nontraditional donors, such as Venezuela, Taiwan Province of China, and Mexico. Financing is assumed to continue to be available, no matter what level the debt stock reaches. In the medium term growth remains driven by the public sector, mainly through large-scale construction, but is still lower (by about one half of 1 percent) than under the active scenario. On the revenue side, the introduction of the VAT yields no additional revenues and the government continues to absorb any additional cost of higher world oil prices. On the expenditure side, there is relatively little reduction in the wage bill, and public sector capital expenditures increase by around 5 percent of GDP. Under this scenario, the public sector primary deficit would deteriorate rapidly (peaking at around 10 percent of GDP by 2008), and public debt would reach about 107 percent of GDP by 2011 (see Table 6, Scenario I).

Active scenario. A fiscal adjustment of 2 percent of GDP is assumed for 2006 (see main text) and further adjustment over the medium term, with the central government primary balance moving from a deficit of 2.6 percent of GDP in 2005 to a surplus of 2.9 percent of GDP by 2011. The adjustment in 2006 is expected to be realized through additional revenues and reduction in expenditure. Greater revenue mobilization is mainly achieved by increased petroleum product taxes, through an automatic adjustment of domestic retail prices (yielding around one half of a percent of GDP), and higher capital revenues (land sales), while on the expenditure side growth of the wage bill will be curbed (through the cessation of new hires and ad-hoc bonuses), and low-priority capital projects will be eliminated or postponed.

Over the medium-term, the main source of additional revenues are the introduction of a revenue-positive VAT, and the introduction of market-valuation based property tax. On the expenditure side, growth in the wage bill will be minimal (by holding constant the number of civil servants and refraining from ad hoc end-year bonuses), while capital expenditure will be 
curtailed by the elimination of low-priority capital projects such as the renovation of the sports stadium.

With the impetus from public sector capital projects, the underlying growth is expected to accelerate with the greater activity in the private sector, and is estimated at about 5 percent of GDP over the medium term. In this scenario, the debt stock would fall to 76 percent of GDP by 2011 (Table 6, Scenario II). 


\section{Appendix I. St. Vincent and the Grenadines-Relations with the Fund}

(As of October 31, 2006)

I. Membership Status: Joined: December 28, 1979; Article VIII.

II. General Resources Account:

Quota

Fund holdings of currency

Reserve Position

Holdings Exchange Rate

III. SDR Department:

Net cumulative allocation

Holdings
SDR Million

8.30

7.80

0.50

SDR Million

0.35

0.00
\%Quota

100.00

93.98

6.02

IV. Outstanding Purchases and Loans: None

V. Latest Financial Arrangements: None

VI. Projected Payments to Fund

(SDR Million; based on existing use of resources and present holdings of SDRs):

\begin{tabular}{lccccr} 
& \multicolumn{5}{c}{ Forthcoming } \\
Principal & 2006 & 2007 & 2008 & 2009 & 2010 \\
Charges/Interest & 0.01 & 0.01 & 0.01 & 0.01 & 0.01 \\
Total & $\underline{0.01}$ & $\underline{0.01}$ & $\underline{0.01}$ & $\underline{0.01}$ & $\underline{0.01}$
\end{tabular}

VII. Implementation of HIPC Initiative: Not Applicable.

VIII. Implementation of MDRI Assistance: Not Applicable.

\section{Exchange Arrangement:}

St. Vincent and the Grenadines is a member of the Eastern Caribbean Central Bank (ECCB), which manages monetary policy and the exchange system for its eight members. The common currency, the Eastern Caribbean dollar, has been pegged to the U.S. dollar at the rate of EC\$2.70 per U.S. dollar since July 1976. In practice the ECCB has operated like a quasi-currency board, maintaining foreign exchange backing of its currency and demand liabilities of close to 100 percent. The exchange system is free of restrictions on the making of payment and transfers for current international transactions. 


\section{Safeguards Assessment:}

Under the Fund's safeguards assessment policy, the Eastern Caribbean Central Bank (ECCB), of which St. Vincent and the Grenadines is a participating government, is subject to a full safeguards assessment. The onsite safeguards assessment was completed on February 20, 2003, and concluded that the ECCB has in place appropriate mechanisms to manage resources, including Fund disbursements and that the vulnerabilities that remain do not present an undue risk. The safeguards assessment proposed specific measures to address these vulnerabilities, which have been substantially implemented by the ECCB.

\section{Last Article IV Consultation:}

The last Article IV consultation was concluded by the Executive Board on July 13, 2005; the relevant documents were published as IMF Country Reports No. 06/205 and 06/206. St. Vincent and the Grenadines is on the standard 12-month consultation cycle. The authorities have not accepted the Fourth Amendment of the Fund's Articles of Agreement.

\section{FSAP Participation, ROSCs, and OFC Assessments:}

St. Vincent and the Grenadines participated in the regional ECCU FSAP conducted in September and October 2003. The Financial System Stability Assessment is IMF Country Report No. 04/293. A review of St. Vincent and the Grenadines AML/CFT Assessment was conducted by a team of assessors representing the Caribbean Financial Action Taskforce (CFATF) in September 2003. A ROSC for Basle Core Principles Assessment of St. Vincent and the Grenadines' offshore banking sector was completed in April 2004, and published as IMF Country Report 04/305.

\section{Technical Assistance: (2005-present)}

During 2005 and 2006, St. Vincent and the Grenadines has benefited from technical assistance in the areas of tax policy, tax administration, economic statistics, financial supervision and macroeconomic management, both from IMF headquarters and the Caribbean Regional Technical Assistance Center (CARTAC).

- $\quad$ Experts from CARTAC and the IMF's Statistics Department (STA) advised the Central Statistics Office on improving the national accounts, and developing exportimport price indices.

- $\quad$ Experts from CARTAC, the IMF's Monetary and Capital Markets Department (MCD), and the IMF's Legal Department (LEG) advised the authorities on amendments to the Building Societies Act, and strengthening financial supervision and regulation. 
- In 2005 and 2006, CARTAC assisted the Ministry of Finance in updating their public financial projections particularly on the debt implications of large public sector investments.

- $\quad$ CARTAC, the IMF's Fiscal Affairs Department (FAD) and LEG provided extensive assistance, through frequent expert visits, to help design and implement a Value Added Tax (VAT).

Further IMF technical assistance is planned in 2007. CARTAC experts will continue to assist the authorities in the post-implementation period of the VAT, while headquarters-based missions from FAD are expected to provide assistance in strengthening tax administration. 


\title{
Appendix II. St. Vincent and the Grenadines-Relations with the World Bank Group
}

\author{
(As of October 31, 2006)
}

The World Bank's Management presented to its Board the Eastern Caribbean Sub-Region Country Assistance Strategy (CAS), on September 13, 2005. The World Bank Group's strategy for the four years covered by this CAS (FY06-09) supports the sub-region's development agenda through two main pillars: (1) stimulating growth and improving competitiveness; and (2) reducing vulnerability, by promoting greater social inclusion and strengthening disaster risk management. Recognizing the OECS countries' weakened creditworthiness due to high debt ratios, Bank activities will focus on leveraging available donor grant financing. Following the recommendations of the recently completed growth and competitiveness study for the OECS, IBRD and IDA support would focus on providing technical and financial assistance for interventions to support the two main pillars. An indicative Base Case lending scenario consists of about US\$51.3 million in IDA resources for the four OECS blend countries (Dominica, Grenada, St. Lucia and St. Vincent and the Grenadines). This amount includes the estimated IDA country allocations for each of the four countries during FY06-09, and an IDA Regional allocation of US\$15.2 million for two regional projects: US\$12 million for Catastrophe Risk Insurance and US\$3.2 million for Infrastructure and Utilities Reform. Planned lending to St. Vincent and the Grenadines amounts to US\$12.6 million under the Base Case lending scenario and consists of the Public Sector Modernization Infrastructure and Utilities Reform investment project.

\section{Projects}

There are three active World Bank projects in St. Vincent and the Grenadines for a net commitment of approximately US\$13.7 million.

The Telecommunications \& ICT Development Project, approved in September 2005, aims at improving the access, quality, and use of telecommunications and ICT services to achieve socio-economic development in the Organization of Eastern Caribbean States (OECS). The project has the following four components: Component (1) will strengthen the national and regional regulatory frameworks and promote additional competition in the telecommunications sector. Emphasis will be given to capacity building of Eastern Caribbean Telecommunications Authority (ECTEL) and the National Telecommunications Regulatory Commissions (NTRCs) by providing them with assistances to revise the regional and national sector legislation, and develop a modem interconnection regime. Component (2) will review current universal access policy, create related guidelines, and provide financial support to establish a Universal Service Fund (USF). Component (3) will improve growth and competitiveness in ICT-enabled services through utilization of broadband infrastructure. Component (4) will finance management and administration of the overall project. The project will finance related technical assistance by providing complementary resources. 
The St. Vincent and the Grenadines Education Reform Project approved in June 2004 for US\$6.2 million. The overall objective of this project is to build human capital which, in turn, will contribute to the diversification of the economy and more sustainable growth. This objective will be achieved by: (i) increasing equitable access to secondary education; (ii) improving the quality of the teaching and learning process, with more direct interventions at the school level and a focus on student-centered learning, and (iii) strengthening management of the sector and governance of schools.

The HIV/AIDS Prevention and Control Program, which was approved in July 2002, is funded under the Multi-Country APL for the Caribbean Region, with the following objectives: (i) curbing the spread of HIV/AIDS epidemic; (ii) reducing the morbidity and mortality attributed to HIV/AIDS; (iii) improving the quality of life for persons living with HIV/AIDS (PLWAs); and (iv) developing a sustainable organizational and institutional framework for managing the HIV/AIDS epidemic over the longer term. The Bank's support to St. Vincent and the Grenadines under this project is for US\$7.0 million.

\section{ECONOMIC AND SECTOR WORK}

The Bank has completed a series of analytical work relating to: public sector capacity in the OECS including the Institutional and Organizational Capacity Review, the OECS Procurement Assessment Review, the OECS Financial Accountability Assessment and an Infrastructure Services Studies. In conjunction with the IMF, a Financial Sector Assessment Program (FSAP) was completed in early 2004. The Bank also recently completed an OECS study on Growth and Competitiveness. A review of large scale energy options for the OECS, under the Energy Sector Management Assistance Program, was completed in February 2006. For St. Vincent and the Grenadines specifically, the Bank recently completed an Analysis of Fiscal Issues, which examines the management and allocation of public expenditure.

St. Vincent and the Grenadines will also benefit from ongoing and planned analytical and advisory activities to support the new CAS' two main pillars including the following activities: Caribbean Air Transport Rationalization report, a Caribbean Skills and Curriculum Study, Caribbean Financial Sector and Regulation report, Caribbean Social Protection Strategy Review, a regional study on Crime and Violence. 


\section{Financial Relations}

(In millions of U.S. dollars)

\section{Operation}

TELECOM AND ICT DEVELOPMENT EDUCATION REFORM PROJECT HIVIAIDS PREVENTION AND CONTROL

Total

1/ Amounts may not add up to original principal due to changes in the
Original Principal

0.54

6.20

7.00

13.74
0.05

0.46

0.02

0.52

\section{Undisbursed1/}

0.51

5.89

6.24

12.65

\section{Disbursements and Debt Service (Fiscal Year Ending June 30)}

\begin{tabular}{lllllllllc}
\hline & \multicolumn{1}{c}{ Actual } \\
\cline { 2 - 9 } & 1999 & 2000 & 2001 & 2002 & 2003 & 2004 & 2005 & 2006 & $20071 /$ \\
\hline Total disbursements & 0.22 & 0.02 & 0.36 & 1.46 & 1.73 & 1.20 & 2.48 & 4.55 & 1.20 \\
Repayments & 0.11 & 0.13 & 0.12 & 0.12 & 0.29 & 0.14 & 0.27 & 0.30 & 0.14 \\
Net disbursements & 0.11 & 0.10 & 0.24 & 1.34 & 1.44 & 1.06 & 2.21 & 4.25 & 1.06 \\
Interest and fees & 0.08 & 0.00 & 0.03 & 0.07 & 0.12 & 0.13 & 0.19 & 0.21 & 0.10 \\
\hline 1/ Data as of Oct. 31, 2006 & & & & & & & & &
\end{tabular}




\section{Appendix III. St. Vincent and the Grenadines-Relations with the Caribbean Development Bank}

(As of October 31, 2006)

The Caribbean Development Bank (CDB) has approved loans totaling US\$147 million, of which US\$34.5 million are undisbursed.

\section{Major Projects:}

- $\quad$ Third Power Project - is geared towards improving the operational capability and reliability of St. Vincent Electricity Services Limited (VINLEC) in order to meet the projected demand for electricity to the end of 2008.

- Basic Education Project (Second Loan) — is to assist the Government of St. Vincent and the Grenadines in enhancing the learning environment through improvements in delivery of pre-primary and basic education within St. Vincent and the Grenadines. Components include the construction of four schools; the upgrading of knowledge, skills and competencies of education managers, planners and supervisors; and professional development of teachers, trainers, principals and other key school personnel.

- $\quad 3 r d$ Road Project (Windward Highway) - to reconstruct approximately 23 kilometers of the Windward Highway; the realignment of the road at 6 locations; widening and lining of the Byera tunnel to provide pedestrian access; and rehabilitation of 13 bridges.

- $\quad$ Student Loan Scheme (Sixth Loan) — to provide loans to student for upgrading skills at the professional, technical and vocation levels.

- $\quad$ Caribbean Court of Justice - to provide for the establishment and operation of a final Court of Appeal to replace the Judicial Committee of the Privy Council and to act as a final arbiter in disputes arising between CARICOM member states or between a CARICOM national and another country. 
I. CURRENT PORTFOLIO

(In millions of U.S. dollars)

\begin{tabular}{lcc}
\hline & Approved & Undisbursed \\
\hline Third Power Project & 18.3 & 9.6 \\
Basic Education (Second Loan) & 17.6 & 16.9 \\
$3^{\text {rd }}$ Road Project_-Windward Highway & 10.6 & 5.0 \\
Student Loan Scheme (Sixth Loan) & 3.5 & 1.9 \\
Line of Credit (Third Loan) & 2.4 & 0.4 \\
OECS Solid Waste Project (add. Loan) & 2.0 & 0.2 \\
\hline
\end{tabular}

II. LOAN DISBURSEMENT

(In millions of U.S. dollars)

\begin{tabular}{|c|c|c|c|c|c|}
\hline & $\mathbf{2 0 0 2}$ & $\mathbf{2 0 0 3}$ & $\mathbf{2 0 0 4}$ & $\mathbf{2 0 0 5}$ & $\mathbf{2 0 0 6}^{\mathbf{1}}$ \\
\hline Net Disbursement & 3.80 & 0.96 & 1.52 & 4.01 & 6.39 \\
\hline Disbursement & 5.93 & 3.88 & 4.61 & 7.35 & 9.18 \\
\hline Amortization & 2.13 & 2.92 & 3.09 & 3.34 & 2.79 \\
\hline Interest and charges & 1.82 & 1.92 & 1.99 & 2.11 & 2.53 \\
\hline Net resource flow & 1.98 & -0.96 & -0.47 & 1.90 & 3.86 \\
\hline
\end{tabular}

1/ As of October 31. 


\title{
Appendix IV. St. Vincent and the Grenadines-Statistical Issues
}

\author{
(As of November 13, 2006)
}

St. Vincent and the Grenadines participates in the General Data Dissemination System (GDDS) since September 2000, and its metadata are posted on the Dissemination Standards Bulletin Board (DSBB). St. Vincent and the Grenadines' statistical database remains weak in terms of coverage, consistency, periodicity, and timeliness. While in areas central to surveillance - notably central government accounts, indicators of the financial sector and external sector accounts - the data are adequate for surveillance purposes, information on the rest of the public sector and nonbank financial intermediaries is limited. Major improvements are needed to facilitate effective surveillance, particularly in the coverage of national accounts (especially the tourism sector and related services), and on data used to monitor labor markets. Efforts to address the weaknesses in the statistical base have been hampered by low response rates to surveys (less than 50 percent), and high turnover of staff.

National Accounts: National accounts by sector are provided with a one-year lag, with inadequate coverage of economic activity in the informal sector. There is a need to upgrade compilation of methodology from the 1968 System of National Accounts to the 1993 System of National Accounts. In addition, data on GDP broken down by type of expenditure are not available at constant prices, while data at current prices are not reliable due to weaknesses in estimating gross capital formation. Private final consumption expenditure is estimated as a residual.

Prices: Data on the consumer price index (CPI) are reported regularly with a two-month lag. CARTAC has assisted in linking the 1981-based CPI series to the 2001-based one, as part of the Fund assisted program on Constructing Weights for the Harmonized Consumer Price Index in the Eastern Caribbean Currency Union (ECCU).

Labor: The Statistical Office has not published official data on unit labor costs and employment. Results of the 2001 population census have been analyzed and published.

Public finance: The IMF publishes annual data for the consolidated general government in the GFS Yearbook, with the 2005 edition showing annual data to 2004. Only cash data are shown, with a detailed classification of revenue and a functional, but not economic, classification of expenditure. No financing information is provided. The 2005 GFS Yearbook shows no balance sheet data but the 2004 edition published domestic and foreign liabilities for 2001. Due to delays in reporting capital expenditures by some ministries, quarterly revenue and expenditure data for the central government are provided to the Fund with some lag. Discrepancies exist between the fiscal and monetary accounts, between above and below the line for budget data, and between financing and debt data. Although domestic debt figures are now available following implementation of the Commonwealth Secretariat-Debt 
Recording and Management System, the domestic debt amortization figures are incomplete. The financial reports of public enterprises are not timely, with about a two-year lag.

Monetary statistics: Monetary data are compiled by the ECCB on a monthly basis. The data are reported regularly to the Fund, although the timeliness of data could be improved. There is also a need to improve the institutional coverage that currently only comprises the ECCB and commercial banks. Full implementation of recommendations made by the monetary and financial statistics missions conducted in August 2003 and December 2005 would ensure consistency with international best practice.

Balance of payments: Estimates for St. Vincent and the Grenadines are currently provided on an annual basis by the ECCB, using a format that is not fully consistent with BPM5. There is a need to improve the compilation of capital and financial account transactions in the balance of payments. In addition, the recording of the stock of private and public debt should be improved. 


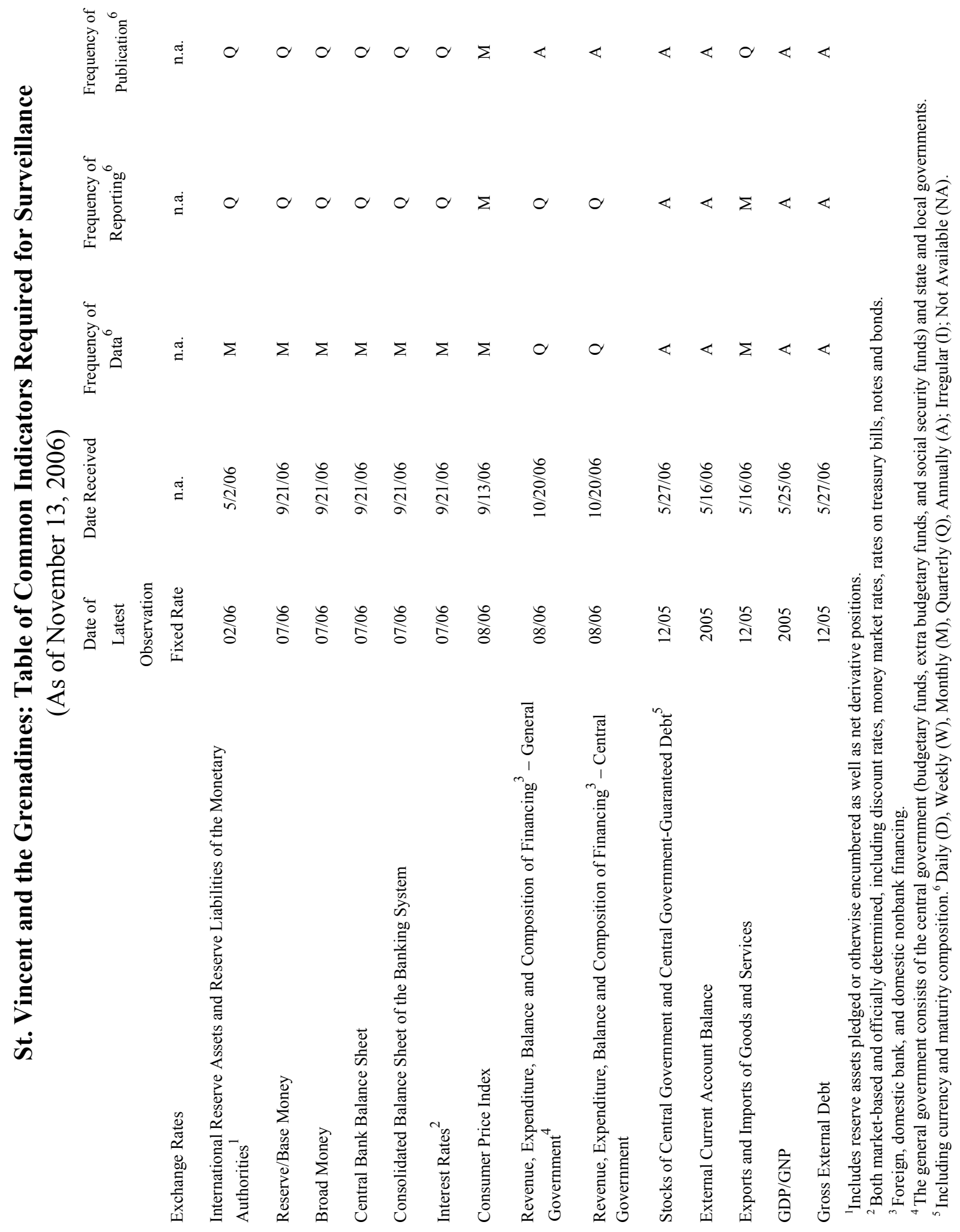




\section{Statement by the IMF Staff Representative \\ January 17, 2007}

1. The following information has become available since the staff report was issued to Executive Directors. The thrust of the staff appraisal remains unchanged.

2. Recent data confirm that macroeconomic developments have been favorable. The authorities' preliminary estimates indicate that GDP growth in 2006 reached about $6 \frac{1}{2}$ percent, driven by a more rapid than expected pick up in construction activity. Following recent increases in domestic petroleum prices, consumer prices increased by 4.3 percent in the 12 months ending November 2006, in line with staff estimates.

3. Fiscal performance appears to have been weaker than earlier estimated. Data for the second half of 2006 show strong revenue performance, driven by the increase in fuel prices and rising stamp duty revenues, but also a faltering of spending discipline due to both rising capital expenditure and (particularly in the fourth quarter) higher current expenditure on wages, transfers and subsidies. As a result, staff now estimates that the central government overall deficit for 2006 is likely to be close to 5 percent of GDP, with the primary deficit of 1 percent of GDP exceeding the staff's recommendation by about one half of one percent of GDP (see attached table).

\section{Assuming capital spending implementation and grant receipts are at historical} rates, the 2007 Budget, which was tabled in Parliament on December 11, would yield some fiscal consolidation, albeit less than recommended by the staff. Overall revenue (including grants) is dipping slightly as a share of GDP, as a sharp rise in external grants largely offsets the effects of a cut in petroleum prices from EC\$11.50 to EC\$9.75 per gallon, a halving of stamp duty, and a reduction in the rate of corporate income tax from 40 percent to $37 \frac{1}{2}$ percent. By lowering expenditures by about 1 percent of GDP, staff estimates that the central government overall deficit for 2007 would likely narrow to around $4 \frac{1}{4}$ percent of GDP, with the primary deficit reaching 0.7 percent of GDP in comparison to the staff's recommendation of a primary surplus of 0.8 percent of GDP (see attached table).

\section{Broader policy commitments in the 2007 Budget include:}

- Tax reform. The government affirmed its commitment to implementing the valueadded tax by May 2007.

- $\quad$ Expenditure reforms. Key priorities for 2007 include: completion of the reclassification exercise for central government employees; implementation of financial management reforms in the civil service, including bringing into operation 
the new Finance Administration and Audit Acts and passage of a new Procurement Bill, which will enhance budgetary control.

- $\quad$ Public debt. The authorities noted their commitment to achieving the fiscal benchmarks recommended by the Monetary Council of the Eastern Caribbean Central Bank - a public sector debt-to-GDP ratio of 60 percent; and a public sector primary balance consistent with achieving and maintaining this ratio over the medium term (that is, by 2020).

\section{The staff has learned that the uniform Banking Act was approved on}

November 20, in line with the 2004 ECCU regional FSAP report. As noted in paragraph 31 of the staff report, this step should help foster a strong and sound domestic banking system.

Summary of Central Government Operations, 2005-07

(In percent of GDP, unless otherwise stated)

\begin{tabular}{|c|c|c|c|c|c|c|}
\hline & $\begin{array}{c}\text { Est. } \\
2005 \\
\end{array}$ & $\begin{array}{c}\text { Est. } \\
\text { SM/06/393 } \\
2006 \\
\end{array}$ & $\begin{array}{c}\text { Est. } \\
2006\end{array}$ & $\begin{array}{c}\text { Active } \\
\text { SM/06/393 } \\
20071 / \\
\end{array}$ & $\begin{array}{c}\text { Budget } \\
2007\end{array}$ & $\begin{array}{c}\text { Staff Est. } \\
\text { Budget } \\
20072 /\end{array}$ \\
\hline Total revenue and grants & 30.5 & 31.1 & 32.7 & 31.7 & 35.0 & 32.4 \\
\hline Current revenue & 29.0 & 29.6 & 31.1 & 30.3 & 29.2 & 29.2 \\
\hline Grants & 1.5 & 1.5 & 1.7 & 1.4 & 5.8 & 3.2 \\
\hline Total expenditure and net lending & 36.1 & 35.4 & 37.6 & 34.3 & 41.9 & 36.6 \\
\hline Current & 27.8 & 27.7 & 28.9 & 26.7 & 28.8 & 28.8 \\
\hline Capital expenditure & 8.3 & 7.6 & 8.7 & 7.6 & 13.1 & 7.9 \\
\hline Net lending & 0.0 & 0.0 & 0.0 & 0.0 & 0.0 & 0.0 \\
\hline Current balance (before grants) & 1.3 & 1.9 & 2.1 & 3.6 & 0.4 & 0.4 \\
\hline Overall balance (cash basis) & -5.6 & -4.2 & -4.9 & -2.6 & -6.8 & -4.2 \\
\hline \multicolumn{7}{|l|}{ Of which } \\
\hline Primary balance & -2.6 & -0.4 & -1.0 & 0.8 & -3.3 & -0.7 \\
\hline Gross central government debt (in percent of GDP) & 72.1 & 70.8 & 71.4 & 67.6 & 72.4 & 69.8 \\
\hline Public sector debt (in percent of GDP) & 81.6 & 84.5 & 85.2 & 83.5 & 88.5 & 85.9 \\
\hline Debt service as a proportion of current revenues & 21.3 & 24.9 & 24.0 & 23.9 & 25.1 & 25.1 \\
\hline GDP at market prices (EC\$ millions) & 1,161 & 1,258 & 1,258 & 1,370 & 1,370 & 1,370 \\
\hline
\end{tabular}

Sources: Ministry of Finance and Planning; and Fund staff estimates and projections.

$1 /$ Under the active scenario current spending is curtailed by holding constant the wage bill and transfers in real terms, while capital expenditure is reduced through the elimination of low-priority capital projects. Current revenues increase by the introduction of the VAT and other revenues are held constant as a share of GDP.

$2 /$ As in the approved budget, except for capital expenditures and grants, for which an execution rate of 60 percent and 55 percent, respectively, is assumed in line with the expected outturn for 2005-06. 


\section{INTERNATIONAL MONETARY FUND}

EXTERNAL

Public Information Notice (PIN) No. 07/134

FOR IMMEDIATE RELEASE

November 13, 2007
International Monetary Fund $70019^{\text {th }}$ Street, NW

Washington, D. C. 20431 USA

\section{IMF Executive Board Concludes 2006 Article IV Consultation with St. Vincent and the Grenadines}

On January 17, 2007, the Executive Board of the International Monetary Fund (IMF) concluded the Article IV consultation with St. Vincent and the Grenadines. ${ }^{1}$

\section{Background}

Economic activity has rebounded, with real GDP growing by over 4 percent in 2006, and further acceleration expected in 2007. The improved performance in 2006 was largely driven by a pick up in construction and tourism-related services, as well as a rebound in weather-affected agricultural production. However, fiscal imbalances continued in 2005 and 2006, with the overall deficit of the central government reaching 51/2 and 41/4 percent of GDP, respectively. Persistent fiscal imbalances have engendered a sharp increase in the stock of public debt, rising from 68 percent of GDP in 2000 to reach about 85 percent of GDP in 2006.

The external current account deficit narrowed in 2005, yet is likely to expand in 2006. The contraction in 2005 was driven by a slowdown in imports due to the weakening of GDP growth, which more than offset a fall in agricultural exports. In 2006, the current account deficit is expected to widen slightly (to about $24 \frac{1}{2} 2$ percent of GDP), mainly on account of continued high oil imports and imports related to private construction and public capital expenditure, despite a rebound in banana exports.

\footnotetext{
${ }^{1}$ Under Article IV of the IMF's Articles of Agreement, the IMF holds bilateral discussions with members, usually every year. A staff team visits the country, collects economic and financial information, and discusses with officials the country's economic developments and policies. On return to headquarters, the staff prepares a report, which forms the basis for discussion by the Executive Board. At the conclusion of the discussion, the Managing Director, as Chairman of the Board, summarizes the views of Executive Directors, and this summary is transmitted to the country's authorities.
} 
The continued depreciation of the U.S. dollar against major currencies has bolstered external competitiveness, particularly since 2002 . Real wage increases have remained modest, and St. Vincent and the Grenadines has steadily increased its share of stayover tourism visitors to the Eastern Caribbean Currency Union and the wider Caribbean. Nonetheless, with rising oil prices and flat export prices, the terms of trade has deteriorated in recent years.

Broad money (M2) growth remained strong in 2005, as bank deposits were used to fund both a surge in net lending to the central government and an expansion in private credit. In 2006, public sector credit increased, due mainly to the funding of several large infrastructure projects.

While prudential indicators of the financial sector and disaster preparedness have both improved in recent years, vulnerabilities remain. Although high government exposures and deposits in the state-owned local bank remain a potential source of vulnerability, asset quality and capital adequacy in the country's commercial banks have risen since 2003. St. Vincent and the Grenadines is one of the world's most disaster-prone countries, yet has made good strides in enhancing disaster preparedness and mitigation, including by development of a National Emergency Response Plan, introduction of a National Building Code, and participation in regional risk pooling.

There has been some progress in implementing broad structural reforms. The authorities continue in their efforts to diversify farm production into non-banana agriculture (through the Agriculture Diversification Program). In order to raise the contribution of tourism to economic activity, the authorities intend to upgrade the country's air transportation infrastructure over the medium term, with construction of an international airport (on St. Vincent) and a jetport (in the Grenadines). The erosion of trade preferences for the country's important banana exports has adversely affected the incomes of rural households, and the authorities have attempted to bolster the country's social safety net to alleviate poverty. On fiscal issues, the authorities intend to enhance revenue raising by the introduction of a value added tax (in May 2007) and a market-valuation based property tax in 2008.

\section{Executive Board Assessment}

Directors welcomed signs that growth has accelerated, but stressed that the challenge remains to develop new sources of growth without compromising fiscal and debt sustainability. The country's fiscal position is of concern, and a front-loaded fiscal adjustment is needed to place the debt ratio on a more sustainable path, increase the scope to address social needs, and enable the economy to respond to adverse shocks. Directors stressed the importance of undertaking major infrastructure investments, including in the air transport sector, only if they are judged viable, and financing them with grants or highly concessional loans.

Directors welcomed the improvements in tax policy and administration, including the planned adoption of the VAT. They called for steps to curb tax concessions and to introduce a flexible retail fuel pricing mechanism to help maintain revenue buoyancy and ensure that the tax system promotes new investment. Directors emphasized that, despite the boost in revenues, stricter spending discipline is needed, through better prioritization of capital spending, limits on civil service employment, and reform of the social security scheme.

Directors welcomed that the financial sector's vulnerability to adverse shocks has been reduced. They supported the ongoing efforts to improve the balance sheet of the state-owned National Commercial Bank and strengthen financial sector supervision. 
Directors supported the efforts made to bolster national disaster mitigation and preparedness. They called for further efforts, including in the context of regional pooling of catastrophe risk insurance.

Directors considered that the erosion of trade preferences for bananas is placing considerable pressure on rural households, which increases the importance of developing a reform program-including well-targeted and temporary safety nets-to ease the transition away from bananas and elicit donor support. In this vein, Directors urged donors to accelerate disbursements to the country of promised aid and grants.

Directors agreed that data with respect to areas central to surveillance are adequate. At the same time, they encouraged the authorities to continue their efforts to improve the coverage, timeliness, and dissemination of statistics, including with technical assistance support from donors and CARTAC.

Public Information Notices (PINs) form part of the IMF's efforts to promote transparency of the IMF's views and analysis of economic developments and policies. With the consent of the country (or countries) concerned, PINs are issued after Executive Board discussions of Article IV consultations with member countries, of its surveillance of developments at the regional level, of post-program monitoring, and of ex post assessments of member countries with longer-term program engagements. PINs are also issued after Executive Board discussions of general policy matters, unless otherwise decided by the Executive Board in a particular case. 
St. Vincent and the Grenadines: Selected Social and Economic Indicators, 2002-07

\begin{tabular}{|c|c|c|c|c|c|c|}
\hline & 2002 & 2003 & 2004 & $\begin{array}{r}\text { Est. } \\
2005 \\
\end{array}$ & $\begin{array}{l}\text { Proj. } \\
2006 \\
\end{array}$ & $\begin{array}{l}\text { Proj. } \\
2007\end{array}$ \\
\hline \multicolumn{7}{|c|}{ (Annual percentage change, unless otherwise specified) } \\
\hline Output and prices & & & & & & \\
\hline Real GDP (factor cost) & 3.2 & 2.8 & 6.8 & 2.2 & 4.1 & 5.5 \\
\hline Nominal GDP (market prices) & 5.8 & 4.6 & 6.7 & 5.5 & 8.3 & 8.9 \\
\hline Consumer prices, end of period & 0.4 & 2.7 & 1.7 & 3.9 & 4.5 & 3.5 \\
\hline Consumer prices, period average & 0.8 & 0.2 & 3.0 & 3.7 & 3.2 & 3.9 \\
\hline \multicolumn{7}{|l|}{ Banking system } \\
\hline Net foreign assets $1 /$ & 2.9 & 5.7 & 15.7 & -4.6 & 1.4 & 1.9 \\
\hline $\begin{array}{l}\text { Net domestic assets } 1 / \\
\text { Of which }\end{array}$ & 5.4 & -3.9 & -2.0 & 11.0 & 6.9 & 6.9 \\
\hline Net credit to the public sector $1 /$ & 4.8 & -4.0 & 2.7 & 7.6 & 4.9 & 4.2 \\
\hline Credit to private sector $1 /$ & 4.3 & 0.6 & 0.8 & 4.3 & 1.7 & 2.9 \\
\hline Broad money 1/ & 8.3 & 1.9 & 13.7 & 6.4 & 8.3 & 8.9 \\
\hline $\begin{array}{l}\text { Average deposit interest rate (in percent per } \\
\text { annum) }\end{array}$ & 4.4 & 4.6 & 3.3 & 2.9 & 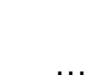 & 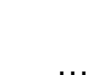 \\
\hline $\begin{array}{l}\text { Average lending interest rate (in percent per } \\
\text { annum) }\end{array}$ & 11.6 & 11.8 & 9.7 & 9.4 & $\cdots$ & $\ldots$ \\
\hline \multicolumn{7}{|c|}{ (In percent of GDP, unless otherwise specified) } \\
\hline \multicolumn{7}{|l|}{$\begin{array}{l}\text { Public sector } \\
\text { Central government finances }\end{array}$} \\
\hline Total revenue and grants & 31.7 & 31.3 & 30.0 & 30.5 & 31.1 & 31.7 \\
\hline Total expenditure and net lending & 34.0 & 34.7 & 33.6 & 36.1 & 35.4 & 34.3 \\
\hline Current expenditure & 28.0 & 26.7 & 26.3 & 27.8 & 27.7 & 26.7 \\
\hline Capital expenditure & 6.4 & 7.9 & 7.2 & 8.3 & 7.6 & 7.6 \\
\hline Overall balance (cash basis) 2/ & -4.2 & -3.3 & -3.6 & -5.6 & -4.2 & -2.6 \\
\hline Primary balance (after grants) & -1.6 & -0.6 & -1.1 & -2.6 & -0.4 & 0.8 \\
\hline Central government debt 3 / & 68.3 & 67.8 & 70.4 & 72.1 & 70.8 & 67.6 \\
\hline Public sector overall balance 4/ & -5.8 & -3.0 & -6.4 & -7.3 & -9.1 & -5.9 \\
\hline Gross public sector debt $3 / 4 /$ & 70.5 & 72.3 & 78.1 & 81.6 & 84.5 & 83.5 \\
\hline \multicolumn{7}{|l|}{ External sector } \\
\hline External current account & -11.5 & -20.8 & -25.1 & -24.0 & -24.5 & -24.9 \\
\hline Stayover arrivals (percentage change) & 9.8 & 1.2 & 10.4 & 9.5 & 5.0 & 7.0 \\
\hline Public sector external debt (end of period) & 46.5 & 50.9 & 54.1 & 54.7 & 53.3 & 50.7 \\
\hline \multicolumn{7}{|l|}{ External public debt service } \\
\hline In percent of exports of goods and services & 6.5 & 7.3 & 10.0 & 11.5 & 13.0 & 12.5 \\
\hline Real effective exchange rate (- = depreciation) $5 /$ & -5.4 & -5.9 & -4.6 & 4.9 & & \\
\hline External terms of trade (- = deterioration) & 2.6 & -4.9 & 0.0 & -4.3 & 0.6 & -2.1 \\
\hline
\end{tabular}

Sources: Eastern Caribbean Central Bank, Ministry of Finance and Planning; Banana Growers' Association, and IMF staff estimates and projections.

$1 /$ Annual changes relative to the stock of broad money at the beginning of the period.

$2 /$ Includes the difference between the overall balance as measured from above the line and from below the line (i.e., financing), which may include float and unidentified discrepancies.

3/ Net of intra-public sector debt (mainly central government debt to the NIS).

4/ The consolidated public sector includes the central government, the National Insurance Services (NIS), Kingstown Board, and ten nonfinancial public enterprises.

5/ The trade weights used for the REER calculation were changed in 2006 for the entire series. 